\title{
The Late Miocene Guacimal Pluton in the Cordillera de Tilarán, Costa Rica: its nature, age and petrogenesis
}

\author{
Vladimír ŽÁČEK ${ }^{*}$, Vojtěch JANOUŠEK ${ }^{1}$, Andrés ULLOA², Jan KOŠLER ${ }^{3}$, Sofia HUAPAYA4, \\ Petr MIXA', Lenka VONDROVICOVÁ', Guillermo E. ALVARADO ${ }^{5,2}$
}

\author{
${ }^{1}$ Czech Geological Survey, Klárov 3, 11821 Prague 1, Czech Republic; vladimir.zacek@geology.cz \\ ${ }^{2}$ Escuela Centroamericana de Geología, Universidad de Costa Rica (UCR), San José, Costa Rica \\ ${ }^{3}$ Centre for Geobiology and Department of Earth Science, University of Bergen, Allegaten 41, N-5007 Bergen, Norway \\ ${ }^{4}$ MINAET, Dirección de Geología y Minas, Apdo. 10104, San José, Costa Rica \\ ${ }^{5}$ Área de Amenazas y Auscultación Sísmica y Volcánica, PySA, ICE, Apdo. 10032-1000, San José, Costa Rica \\ * Corresponding author
}

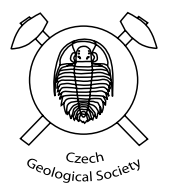

\begin{abstract}
The Guacimal Pluton is situated in the Cordillera de Tilarán in the northwestern Costa Rica. It forms an oval-shaped body strongly elongated in the NW-SE direction. Its dimensions are $\sim 15 \times 4-6 \mathrm{~km}$ with an exposed surface of $60-70$ $\mathrm{km}^{2}$. The pluton intruded basic volcanic rocks of the Aguacate Group (Miocene-Pliocene) and is surrounded by a wide thermal aureole of calc-silicate metasomatic rocks.

The pluton is mainly formed of monzogranites to granodiorites, which strongly prevail over more basic types occuring scarce and relatively thin dykes and enclaves. The dominant magmatic minerals of this felsic suite are quartz, plagioclase, and $\mathrm{K}$-feldspar with subordinate Mg-rich biotite, amphibole I, and magnetite. Orthopyroxene, Mn-rich ilmenite, Al-poor titanite, rutile, apatite, zircon, thorite, and chalcopyrite are accessories. Secondary minerals, which occur as fillings of miarolitic cavities and interstices, are quartz II, K-feldspar II, epidote, chlorite, actinolite, ilmenite II and Al-rich titanite II. The much less frequent mafic suite (mainly quartz diorite to quartz monzodiorite/monzogabbro) is composed of plagioclase, pargasite, actinolite, K-feldspar, quartz and magnetite, with accessory amounts of opaque minerals, epidote, chlorite, and titanite.

The pluton was emplaced at a depth of $c .3 \mathrm{~km}$, crystallized at temperature of $c .760-800{ }^{\circ} \mathrm{C}$ under a relatively high oxygen fugacity (1.6-2.1 log units above the NNO buffer). Increased activities of volatiles $\left(\mathrm{H}_{2} \mathrm{O}, \mathrm{F}\right)$ upon cooling are indicated by the presence of highly aluminous, F-rich titanite and other hydrous silicates in miarolitic cavities. The prevailing, felsic rocks of the Guacimal Pluton are high-K calc-alkaline, whereas the mafic suite is nearly exclusively medium-K calc-alkaline in nature. Laser ablation ICP-MS dating of zircons from two granite samples yielded statistically identical $\mathrm{U}-\mathrm{Pb}$ ages of $6.3 \pm 0.5$ and $6.0 \pm 0.4 \mathrm{Ma}$, respectively. The $\mathrm{Sr}-\mathrm{Nd}$ isotopic compositions are rather primitive $\left({ }^{87} \mathrm{Sr}^{186} \mathrm{Sr}_{6}=0.70380-0.70413, \varepsilon_{\mathrm{Nd}}^{6} \sim+7.3\right.$ to +7.9$)$. Narrow range of these values rules out open-system processes such as magma mixing or assimilation of isotopically contrasting upper continental crust. Instead, the felsic suite is interpreted as either having crystallized from a highly fractionated melt extracted from a plagioclase-amphibole-dominated crystal mush in a putative deep crustal reservoir or a product of partial melting of older arc-related rocks, such as intermediate lavas or volcaniclastics or immature psammitic sediments rich in volcanic material. The observed variation in the felsic suite was most likely produced by low degrees of closed-system fractional crystallization of an assemblage dominated by feldspars. At least some of the rocks of the volumetrically subordinate mafic suite may represent lithologies rich in the complementary cumulates.
\end{abstract}

Keywords: granitic rocks, geochemistry, zircon U-Pb age, Guacimal Pluton, Costa Rica, Central American Volcanic Arc Received: 2 November 2010; accepted: 28 March 2011; handling editor: D. Dolejš

The online version of this article (doi: 10.3190/jgeosci.087) contains supplementary electronic material.

\section{Introduction}

Plutonic rocks occurring in Central America range from Precambrian to Pliocene in age. The older intrusions are mostly situated in the Chortis Block of Guatemala, Honduras and northern Nicaragua but the majority of the youngest plutonic rocks are concentrated in the Chorotega Block in the SE Costa Rica and Panama, where they are associated with the Neogene volcanic front (Weyl
1980; Donelly et al. 1990; Patino 2007). The igneous activity of this, now extinct, Late Miocene to Pliocene volcanic front produced rocks of highly variable nature, ranging from mostly tholeiitic to calc-alkaline, that form extensive volcanic deposits and numerous intrusive bodies of various sizes (Denyer and Alvarado 2007, Fig. 1).

The largest plutonic complex is represented by the Talamanca Intrusive Suite, which extends from E Costa Rica to Panama. This suite includes numerous plutons 


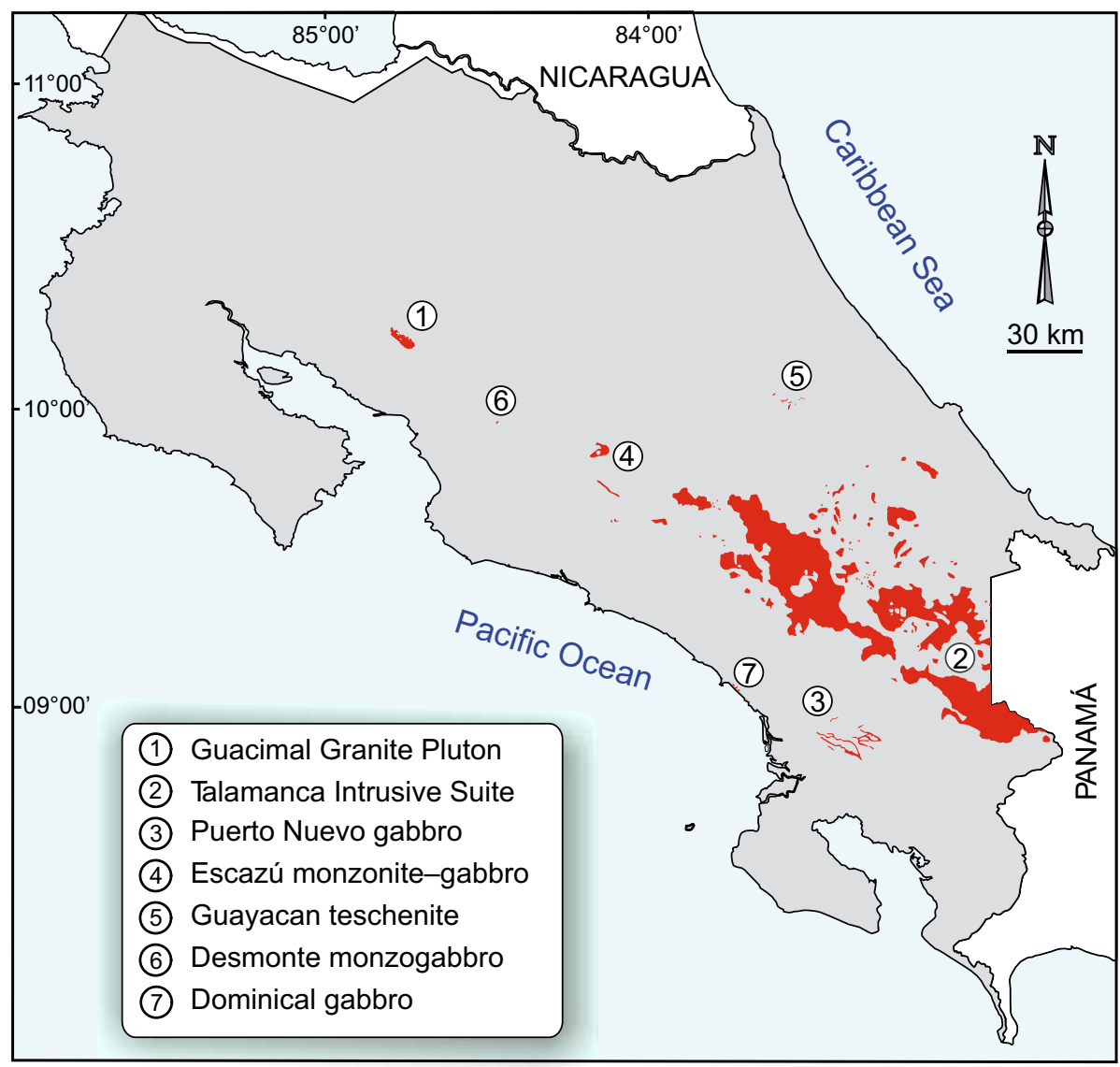

Fig. 1 Sketch map of Costa Rica with marked Neogene plutons. Modified from Denyer and Alvarado (2007). and stocks of various sizes where monzogranites dominate but gabbros, diorites, granodiorites, and alkaline granites are also found (Kussmaul 1987; Abratis 1998; Drummond et al. 1995; Patino 2007). The age of this igneous complex ranges from 21.6 to $3.5 \mathrm{Ma}$, with most of ages falling between 12 to $8 \mathrm{Ma}$; the granites are considered mostly, but not always, to be the youngest whereas the gabbros are the oldest (Alvarado et al. 1992; de Boer et al. 1995; MacMillan et al. 2004; Patino 2007). The 36 to $3 \mathrm{Ma}$ old intrusive rocks of Panama show a similar compositional range; granodiorites of this suite are associated with an extensive porphyry copper mineralization (Kessler et al. 1977).

Other Neogene plutonic bodies in Costa Rica are much less voluminous but very varied. North of the Cordillera de Talamanca, small intrusions of teschenites were reported together with monzonites and syenites with feldspathoids (Guayacán suite) dated at $4.5 \mathrm{Ma}$ (Azambre and Tournon 1977; Patino 2007). Other small intrusive bodies are monzonites to gabbros at Escazú, which were dated from 6.3 to $2.2 \mathrm{Ma}$ (Kussmaul 1987; de Boer et al. 1995), gabbros at Puerto Nuevo (or Dominical Gabbros, c. 14-11 Ma; Appel 1990; de Boer et al. 1995; MacMillan et al. 2004; Gazel et al. 2009) and a small stock of monzogabbro at Desmonte (2.1 Ma, Bellon and Tournon 1978) (see Fig. 1).

In the NW Costa Rica, the Guacimal Pluton is an isolated body situated in the Cordillera de Tilarán (Chaves and Sáenz 1974; Cigolini and Chaves 1986; Kussmaul 1987; Denyer and Alvarado 2007). Whereas the large granitic bodies in the Cordillera de Talamanca were studied extensively because of their ore potential (porphyry copper deposits), the information about the Guacimal Pluton remains fragmentary.

Our recent detailed geological survey provided new data on the size and shape, petrology, geochemistry, and age of this plutonic body. Preliminary results were presented in the form of conference abstracts or short reports (e.g. Žáček et al. 2008) and three published sheets of geological maps on the scale 1: 50000 (Žáček et al. 2010a-c). However most of the information remained in the form of an unpublished final report (Kycl et al. 2010), which was handed over to the Costa Rican partner (MINAET, Dirección de Geología y Minas, San José) in March 2010. The current paper represents the first contribution in a series, and it is devoted to petrology, mineral chemistry, wholerock and $\mathrm{Sr}-\mathrm{Nd}$ isotope geochemistry as well as possible petrogenesis of this intriguing plutonic body. 


\section{Geological setting}

The studied area is situated in the NW Costa Rica, and it belongs to Montes del Aguacate and Cordillera de Tilarán. It is built by various geological units of Lower Cretaceous to Quaternary age but mainly of the Miocene to Pleistocene basaltic and andesitic lavas (Dengo 1962). The oldest unit is the Complex of Nicoya formed of basalts and peridotites, which represent relics of the Early Cretaceous ocean floor (Alvarado et al. 1997; Baumgartner and Denyer 2006; Denyer et al. 2006). Several sedimentary and volcanosedimentary formations of Upper Cretaceous to Miocene age rest unconformably on this ophiolitic suite (Astorga 1987; Denyer and Arias 1991). However, the basement of the studied area is dominated by volcanic rocks, mainly lavas and volcaniclastics of basaltic to andesitic composition. On the basis of more than $200 \mathrm{~K}-\mathrm{Ar}$ ages, the development of this extinct volcanic arc (Central America Cordillera) started in Early Miocene (c. $24 \mathrm{Ma}$ ). The volcanic activity was episodic with distinct pulses at 16-17, 4-6, and 1-2 Ma (Bellon and Tournon 1978; Amos and Rogers 1983; Alvarado et al. 1992; Gillot et al. 1994; Kussmaul et al. 1994; Gans et al. 2002, 2003).

The older Aguacate Group (c. 23-2 Ma) is cut by various intrusive and subvolcanic bodies of variable composition (rhyolites, dacites, andesites to basalts), and by deeper seated batholiths with smaller stocks of granites, granodiorites, diorites and gabbros (including the Guacimal Pluton). This unit was affected by extensive hydrothermal alteration often associated with the gold mineralization (Laguna 1983, 1984). The presence of numerous gold deposits in this region is obvious from the local name Cinturón de Oro or the Golden Belt (Amos and Rogers 1983; Schulz et al. 1987).

After the volcanic activity of the Aguacate Group ceased, several ignimbrite eruptions occurred in Late Pliocene to Early Pleistocene, relics of which are found mostly in the eastern part of the studied area (Peñas Blancas and Alto Palomo units - Villegas 1997, 2004). After a gap in the Early Pleistocene, the volcanic activity resumed as a consequence of formation of a new volcanic arc, producing andesitic lavas, various types of pyroclastic rocks and lahars, associated with several rhyodacitic to andesitic domes.

In contrast to the older Aguacate Group, the Early Pleistocene Monteverde Formation (1-2 Ma) is characterized by more acidic calc-alkaline volcanism with dominant andesites and by absence of gold-bearing hydrothermal alteration.

The Quaternary period is represented by fluvial sediments, including two levels of terraces and extensive alluvial fans. Accumulations of deposits of giant landslides occur in the mountains.

\section{Methods}

The study area belongs to Guanacaste, Puntarenas, and Alajuela provinces, and it included three topographic map sheets at a scale of 1:50 000 (Miramar, Chapernal and Juntas), thus covering a total area of about $1500 \mathrm{~km}^{2}$.

Magnetic susceptibility of igneous rocks was measured in the field with the KT-5 portable kappameter. Nine whole-rock samples for chemical analyses and/or dating (5 granites, 1 quartz diorite and 2 contact hornfelses; see Tab. 1 and Fig. 2 for sample location and further details) were obtained during field geological mapping in March and April 2009 in the Juntas topographic sheet. Rock samples were crushed in a steel jaw crusher, homogenized and grinded in an agate ball mill. The fine powders were analyzed for whole-rock geochemical composition in the Acme Analytical Laboratories Ltd., Vancouver, Canada. The major and minor elements were determined by ICP-OES (4A analytical package) and most trace elements (Ba, Cs, Ga, Hf, Nb, Rb, Sr, Ta, Th, $\mathrm{U}, \mathrm{V}, \mathrm{Zr}$, Y, and REE) by ICP-MS (4B). The dissolution of the rock powders in both cases followed fusion with a lithium metaborate/tetraborate flux and dilute nitric acid digestion. The analyses of remaining trace elements, and transition metals in particular $(\mathrm{Cu}, \mathrm{Pb}, \mathrm{Zn}, \mathrm{Cr}$ and $\mathrm{Ni})$, were carried out by ICP-MS following dissolution in aqua regia at $95{ }^{\circ} \mathrm{C}(1 \mathrm{DX})$. The detection limits are given in the Table with the analytical data; further details can be found at http://acmelab.com.

At least $5 \mathrm{~kg}$ of three fresh granites (Ju311, Ju328 and Ju346) were crushed in a jaw crusher and zircons were extracted using Wilfley shaking table, heavy liquid (methylene iodide) and magnetic separation at the Czech Geological Survey (CGS) at Prague-Barrandov. The zircon concentrates were finally handpicked.

Electron microprobe analyses were carried out by Cameca SX-100 electron microprobe in the Joint Laboratory of the Masaryk University and of the CGS, Brno (R. Škoda, analyst) in the WDS mode. The minerals were analysed at $15 \mathrm{kV}$ accelerating voltage and $10 \mathrm{nA}$ (feldspars, amphiboles, pyroxenes, micas) or 20 nA beam current (titanite, spinels, ilmenite, rutile). The beam diameter ranged from $\sim 1 \mu \mathrm{m}$ (rutile, ilmenite, magnetite), $4 \mu \mathrm{m}$ (majority of silicates) to $6 \mu \mathrm{m}$ (feldspars). The following standards were used: $U-$ metallic $\mathrm{U}, \mathrm{Pb}-\mathrm{PbSe}, \mathrm{Th}-\mathrm{ThO}_{2}, \mathrm{P}$ - fluorapatite, $\mathrm{Y}-\mathrm{YAG}, \mathrm{La}$ $-\mathrm{LaB}_{6}, \mathrm{Ce}-\mathrm{CeAl}_{2}, \mathrm{Pr}-\mathrm{PrF}_{3}, \mathrm{Nd}-\mathrm{NdF}_{3}, \mathrm{Sm}-\mathrm{SmF}_{3}$, $\mathrm{Gd}-\mathrm{GdF}_{3}, \mathrm{Dy}-\mathrm{DyPO}_{4}, \mathrm{Er}-\mathrm{YErAG}, \mathrm{Yb}-\mathrm{YbAG}$, $\mathrm{Al}$ - almandine, $\mathrm{Si}, \mathrm{Ca}, \mathrm{Fe}$ - andradite, $\mathrm{Mn}$ - rhodonite, $\mathrm{W}$ - scheelite, S - barite, F - topaz, As - InAs, Nb columbite, $\mathrm{Ta}-\mathrm{CrTa}_{2} \mathrm{O}_{6}, \mathrm{Ti}$ - titanite, $\mathrm{Zr}$ - zircon, and $\mathrm{Sc}-\mathrm{ScVO}_{4}, \mathrm{Mg}-$ pyrope and $\mathrm{Sr}-\mathrm{SrSO}_{4}$. Raw data were reduced by the PAP correction (Pouchou and Pichoir 1985). The detection limits were as follows $-\mathrm{Si}$, 
Tab 1 List of samples analysed

\begin{tabular}{|c|c|c|c|c|c|c|c|c|c|}
\hline No & Rock & $\begin{array}{c}\text { GPS } \\
\text { coordinates }\end{array}$ & Locality & $\begin{array}{c}\text { Major minerals } \\
\quad(>10 \%)\end{array}$ & $\begin{array}{l}\text { Minor minerals } \\
\qquad(1-10 \%)\end{array}$ & $\begin{array}{l}\text { Accessory } \\
\text { minerals }\end{array}$ & $\begin{array}{l}\text { Minerals of } \\
\text { miaroles / } \\
\text { secondary } \\
\text { minerals }\end{array}$ & MS & $\begin{array}{l}\text { Analytical } \\
\text { method } \\
\text { applied }\end{array}$ \\
\hline Ju57 & $\begin{array}{c}\text { amphibole } \\
\text { granite } \\
\text { (granophyre) }\end{array}$ & $\begin{array}{l}10^{\circ} 12^{\prime} 59.7^{\prime \prime} \mathrm{N} \\
84^{\circ} 51^{\prime} 00.8^{\prime \prime} \mathrm{W}\end{array}$ & Guacimal & $\begin{array}{c}\text { quartz, } \\
\text { plagioclase, } \\
\text { K-feldspar }\end{array}$ & $\begin{array}{c}\text { amphibole } 5 \% \text {, } \\
\text { magnetite } 2 \%\end{array}$ & $\begin{array}{l}\text { biotite, titanite, } \\
\text { apatite, zircon }\end{array}$ & $\begin{array}{c}\text { epidote, } \\
\text { actinolite, } \\
\text { chlorite }\end{array}$ & $2-8$ & CHA \\
\hline Ju98 & $\begin{array}{c}\text { leucogranite } \\
\text { with amphibole } \\
\text { and biotite }\end{array}$ & $\begin{array}{l}10^{\circ} 16^{\prime} 01.9^{\prime \prime} \mathrm{N} \\
84^{\circ} 49^{\prime} 32.7^{\prime \prime} \mathrm{W}\end{array}$ & San Luis & $\begin{array}{c}\text { quartz, } \\
\text { plagioclase, } \\
\text { K-feldspar }\end{array}$ & $\begin{array}{c}\text { amphibole } 3 \% \text {, } \\
\text { biotite } 1 \% \text {, } \\
\text { magnetite } 1 \%\end{array}$ & $\begin{array}{l}\text { titanite, apatite, } \\
\text { zircon }\end{array}$ & $\begin{array}{l}\text { epidote, } \\
\text { actinolite, } \\
\text { chlorite }\end{array}$ & $5-20$ & $\mathrm{CHA}$ \\
\hline Ju311 & $\begin{array}{l}\text { amphibole } \\
\text { granite with } \\
\text { biotite }\end{array}$ & $\begin{array}{l}10^{\circ} 14^{\prime} 06.8^{\prime \prime} \mathrm{N} \\
84^{\circ} 41^{\prime} 42.0^{\prime \prime} \mathrm{W}\end{array}$ & $\begin{array}{c}\text { San } \\
\text { Antonio }\end{array}$ & $\begin{array}{c}\text { quartz, } \\
\text { plagioclase, } \\
\text { K-feldspar }\end{array}$ & $\begin{array}{c}\text { amphibole } 5 \% \text {, } \\
\text { biotite } 2 \% \text {, } \\
\text { magnetite } 1 \%\end{array}$ & $\begin{array}{l}\text { titanite I, ilmenite, } \\
\text { zircon, apatite, } \\
\text { orthopyroxene, } \\
\text { pargasite }\end{array}$ & $\begin{array}{l}\text { epidote, } \\
\text { chlorite, } \\
\text { actinolite, } \\
\text { titanite II }\end{array}$ & $13-15$ & $\begin{array}{l}\text { CHA, } \\
\text { EMPA, } \\
\text { DAT, } \\
\text { Sr-Nd }\end{array}$ \\
\hline Ju328 & $\begin{array}{l}\text { amphibole } \\
\text { granite }\end{array}$ & $\begin{array}{l}10^{\circ} 16^{\prime} 15.3^{\prime \prime N} \\
84^{\circ} 49^{\prime} 18.4^{\prime \prime} \mathrm{W}\end{array}$ & San Luis & $\begin{array}{c}\text { quartz, } \\
\text { plagioclase, } \\
\text { K-feldspar }\end{array}$ & $\begin{array}{c}\text { amphibole } 5 \% \text {, } \\
\text { magnetite } 2 \%\end{array}$ & $\begin{array}{c}\text { biotite, titanite, } \\
\text { zircon, rutile, } \\
\text { chalcopyrite }\end{array}$ & $\begin{array}{l}\text { chlorite, } \\
\text { epitote }\end{array}$ & $7-16$ & $\begin{array}{l}\text { CHA, } \\
\text { EMPA, } \\
\text { DAT, } \\
\text { Sr-Nd }\end{array}$ \\
\hline Ju346 & $\begin{array}{c}\text { leucogranite } \\
\text { with biotite and } \\
\text { amphibole }\end{array}$ & $\begin{array}{l}10^{\circ} 14^{\prime} 13.4^{\prime \prime N} \\
84^{\circ} 45^{\prime} 00.8^{\prime \prime} \mathrm{W}\end{array}$ & $\begin{array}{c}\text { San } \\
\text { Martín } \\
\text { Norte }\end{array}$ & $\begin{array}{c}\text { quartz, } \\
\text { plagioclase, } \\
\text { K-feldspar }\end{array}$ & $\begin{array}{c}\text { biotite } 3 \% \text {, } \\
\text { amphibole } 1 \% \text {, } \\
\text { magnetite } 1 \%\end{array}$ & $\begin{array}{l}\text { titanite, ilmenite, } \\
\text { apatite, zircon, } \\
\text { thorite }\end{array}$ & $\begin{array}{c}\text { quartz, } \\
\text { K-feldspar, } \\
\text { epidote, } \\
\text { chlorite, } \\
\text { actinolite }\end{array}$ & $21-27$ & $\begin{array}{l}\text { CHA, } \\
\text { EMPA, } \\
\text { DAT, } \\
\text { Sr-Nd }\end{array}$ \\
\hline Ju348 & $\begin{array}{c}\text { amphibole } \\
\text { quartz diorite }\end{array}$ & $\begin{array}{l}10^{\circ} 15^{\prime} 53.0^{\prime \prime} \mathrm{N} \\
84^{\circ} 50^{\prime} 02.0^{\prime \prime} \mathrm{W}\end{array}$ & Guaria & $\begin{array}{l}\text { plagioclase, } \\
\text { amphibole II } \\
\text { (actinolite) }\end{array}$ & $\begin{array}{c}\text { amphibole I, } \\
\text { K-feldspar, } \\
\text { epidote, quartz, } \\
\text { magnetite }\end{array}$ & $\begin{array}{c}\text { titanite, ilmenite, } \\
\text { apatite }\end{array}$ & $\begin{array}{c}\text { c. } 70 \% \\
\text { secondary } \\
\text { assemblage }\end{array}$ & 60 & $\begin{array}{l}\text { CHA, } \\
\text { EMPA }\end{array}$ \\
\hline Ju321a & $\begin{array}{c}\text { hornfels } \\
\text { (cornubianita) }\end{array}$ & $\begin{array}{l}10^{\circ} 17^{\prime} 22.6^{\prime \prime} \mathrm{N} \\
84^{\circ} 49^{\prime} 40.9^{\prime \prime} \mathrm{W}\end{array}$ & San Luis & $\begin{array}{l}\text { diopside, } \\
\text { plagioclase, } \\
\text { K-feldspar, } \\
\text { wollastonite }\end{array}$ & $\begin{array}{c}\text { epidote, } \\
\text { andradite, } \\
\text { quartz, calcite, } \\
\text { chlorite }\end{array}$ & titanite, zircon & $\begin{array}{l}\text { completely } \\
\text { secondary } \\
\text { assemblage }\end{array}$ & 0.20 & $\begin{array}{l}\text { XRD, } \\
\text { CHA, } \\
\text { EMPA }\end{array}$ \\
\hline Ju323 & $\begin{array}{c}\text { hornfels } \\
(\text { cornubianita })\end{array}$ & $\begin{array}{l}10^{\circ} 17^{\prime} 27.5^{\prime \prime} \mathrm{N} \\
84^{\circ} 49^{\prime} 30.8^{\prime \prime} \mathrm{W}\end{array}$ & San Luis & $\begin{array}{c}\text { quartz, calcite, } \\
\text { epidote, } \\
\text { plagioclase, } \\
\text { diopside }\end{array}$ & $\begin{array}{c}\text { chlorite, pyrite, } \\
\text { smectite }\end{array}$ & & $\begin{array}{l}\text { completely } \\
\text { secondary } \\
\text { assemblage }\end{array}$ & $0.1-0.5$ & XRD, CHA \\
\hline $\mathrm{Ju} 327$ & $\begin{array}{c}\text { hornfels } \\
\text { (cornubianita) }\end{array}$ & $\begin{array}{l}10^{\circ} 16^{\prime} 18.9^{\prime \prime} \mathrm{N} \\
84^{\circ} 47^{\prime} 53.7^{\prime \prime} \mathrm{W}\end{array}$ & San Luis & $\begin{array}{l}\text { clinozoisite- } \\
\text { epidote, } \\
\text { actinolite, } \\
\text { prehnite }\end{array}$ & $\begin{array}{c}\text { quartz, } \\
\text { plagioclase }\end{array}$ & titanite & $\begin{array}{l}\text { completely } \\
\text { secondary } \\
\text { assemblage }\end{array}$ & $0.3-0.5$ & $\begin{array}{l}\text { CHA, } \\
\text { EMPA }\end{array}$ \\
\hline
\end{tabular}

MS - magnetic susceptibility $\left(10^{-3} \mathrm{SI}\right)$

Al, Ca, Cr: 100-200 ppm; Mg, Na, K, Fe, Mn, V, Y, Cl, Ti, Nb, As, P, S: 200-500 ppm; F, Ni, Zn, La, Ce, U, Th, Pb: 500-1000 ppm; Pr, Nd, Sm, Gd, Dy, Er, Yb, Ba, Ta, W: $>1000 \mathrm{ppm}$. The mineral abbreviations used are after Kretz (1983).

X-ray powder diffraction data were acquired using the Phillips X'pert MPD System $(\mathrm{Cu}$ radiation, graphite secondary monochromator) at CGS, Prague by I. Haladová. The data were processed by the Bede ZDS
Search/Match software (Ondruš and Skála 2004). This method was mainly used for mineral identification in hydrothermally altered rocks including contact metasomatic rocks.

For the radiogenic isotope determinations, samples were dissolved using a combined $\mathrm{HF}-\mathrm{HCl}-\mathrm{HNO}_{3}$ digestion. Strontium and neodymium were isolated from the bulk matrix by the exchange chromatography techniques using Triskem's Sr resin (equivalent to Sr.spec) and Ei- 


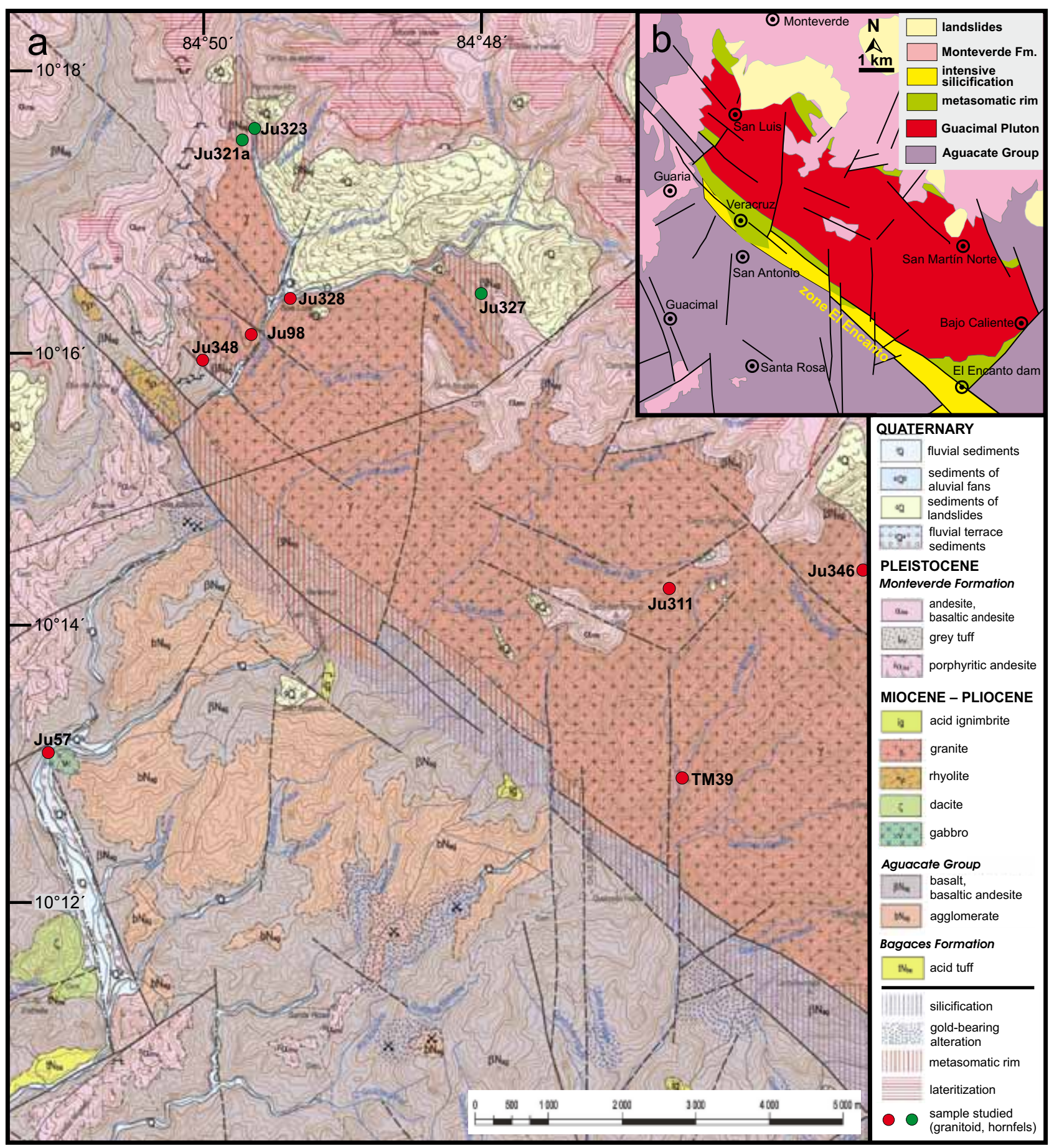

Fig. 2 Geological map of the studied area with the sample locations. a - The section from the eastern part of the geological map 1:50 000, sheet 3246-IV Juntas (Žáček et al. 2010c). b - Geological sketch map of the Guacimal Pluton, complemented by unpublished manuscript geological map (of Vladimír Žáček) in the neighbouring sheet San Lorenzo.

chrom's TRU.spec and Ln.spec (Pin et al. 1994; Pin and Zalduegui 1997; Míková and Denková 2007). Isotopic analyses of $\mathrm{Sr}$ and $\mathrm{Nd}$ were performed on a Finnigan MAT 262 thermal ionization mass spectrometer housed at CGS in dynamic mode using a single Ta filament for $\mathrm{Sr}$ and double Re filament assembly for $\mathrm{Nd}$. The ${ }^{143} \mathrm{Nd} /{ }^{144} \mathrm{Nd}$ ratios were corrected for mass fractionation to ${ }^{146} \mathrm{Nd} /{ }^{144} \mathrm{Nd}$ $=0.7219$ (Wasserburg et al. 1981), ${ }^{87} \mathrm{Sr} /{ }^{86} \mathrm{Sr}$ ratios assuming ${ }^{86} \mathrm{Sr} r{ }^{88} \mathrm{Sr}=0.1194$. External reproducibility is estimated from repeat analyses of the JNdi- $1\left({ }^{143} \mathrm{Nd} /{ }^{144} \mathrm{Nd}\right.$ $=0.512100 \pm 262 \sigma, \mathrm{n}=7)$ and NBS $987\left({ }^{87} \mathrm{Sr} /{ }^{86} \mathrm{Sr}=\right.$ $0.710244 \pm 24(2 \sigma), \mathrm{n}=14)$ reference materials. 
Zircon grains for the laser ablation ICP-MS dating were mounted in 1 inch epoxy-filled blocks and polished to obtain even surfaces suitable for cathodoluminescence (CL) imaging and laser ablation inductively coupled plasma mass spectrometry (LA ICP-MS) analysis. Prior to analysis by LA ICP-MS, the sample surfaces were cleaned in $5 \% \mathrm{HNO}_{3}$, deionized water and ethanol. Isotopic analyses followed the technique described in detail by Košler et al. (2002). A Thermo-Finnigan Element 2 sector field ICP-MS coupled to a 213 NdYAG laser (New Wave UP-213) at the Bergen University was used to measure $\mathrm{Pb} / \mathrm{U}$ and $\mathrm{Pb}$ isotopic ratios in zircons. The sample introduction system was modified to enable simultaneous nebulisation of a tracer solution and laser ablation of the solid sample (Horn et al. 2000). Natural $\mathrm{Tl}\left({ }^{205} \mathrm{Tl} /{ }^{203} \mathrm{Tl}=2.3871-\right.$ Dunstan et al. 1980$),{ }^{209} \mathrm{Bi}$ and enriched ${ }^{233} \mathrm{U}$ and ${ }^{237} \mathrm{~Np}(>99 \%)$ were used in the tracer solution, which was aspirated to the plasma in an $\mathrm{Ar}-\mathrm{He}$ carrier gas mixture through an Apex desolvation nebuliser (Elemental Scientific) and a T-piece tube attached to the back end of the plasma torch. A helium gas line carrying the sample from the laser cell to the plasma was also attached to the T-piece tube. The laser was set up to produce energy density of ca $1.5 \mathrm{~J} / \mathrm{cm}^{2}$ at a repetition rate of $20 \mathrm{~Hz}$. The sample was placed in a low volume (c. 2 $\mathrm{cm}^{3}$ ) tear-drop ablation cell, which was mounted on a computer-driven motorised stage of a microscope. During ablation, the stage was moved beneath the stationary laser beam to produce a linear raster $(c .50-100 \times 60 \mu \mathrm{m})$ in the sample. Typical acquisitions consisted of a 35 second measurement of analytes in the gas blank and aspirated solution, particularly ${ }^{203} \mathrm{Tl}-{ }^{205} \mathrm{Tl}-{ }^{209} \mathrm{Bi}-{ }^{233} \mathrm{U}-{ }^{237} \mathrm{~Np}$, followed by measurement of $\mathrm{U}$ and $\mathrm{Pb}$ signals from zircon, along with the continuous signal from the aspirated solution, for another 120 seconds. The data were acquired in time resolved - peak jumping - pulse counting mode with 1 point measured per peak for masses 202 (flyback), 203 and $205(\mathrm{Tl}), 206$ and $207(\mathrm{~Pb}), 209(\mathrm{Bi}), 233(\mathrm{U})$, 237 (Np), 238 (U), 249 ( ${ }^{233} \mathrm{U}$ oxide), $253\left({ }^{237} \mathrm{~Np}\right.$ oxide) and $254\left({ }^{238} \mathrm{U}\right.$ oxide). Raw data were corrected for dead time of the electron multiplier and processed off line in a spreadsheet-based program (Lamdate; Košler et al. 2002) and plotted on concordia diagrams using Isoplot (Ludwig 1999). Data reduction included correction for gas blank, laser-induced elemental fractionation of $\mathrm{Pb}$ and $\mathrm{U}$ and instrument mass bias. Minor formation of oxides of $U$ and $\mathrm{Np}$ was corrected for by adding signal intensities at masses 249,253 and 254 to the intensities at masses 233, 237 and 238, respectively. Details of data reduction and corrections are described in Košler et al. (2002) and Košler and Sylvester (2003). Zircon reference material GJ-1 (609 Ma - Jackson et al. 2004) was periodically analysed during this study and it yielded a concordia age of $598 \pm 12 \mathrm{Ma}$.

\section{Geology of the Guacimal Pluton}

The Guacimal Pluton is situated in the mountainous area of S and SW slopes of the Cordillera de Tilarán in the NW Costa Rica (Guanacaste and Alajuela departments). The pluton is approximately limited by grid co-ordinates $\mathrm{N} 10^{\circ} 11^{\prime}-10^{\circ} 17^{\prime}$ and $\mathrm{W} 84^{\circ} 43^{\prime}-84^{\circ} 50^{\prime} \mathrm{W}$. Majority (c. $85 \%$ ) of the pluton surface is exposed on the Juntas map sheet (Žáček et al. 2010c, see Fig 2a), only its easternmost part belongs to the neighbouring San Lorenzo sheet. The Guacimal Pluton was first described by Chaves and Sáenz (1974), several chemical analyses were published by Alcorn (1981) and Cigoliny and Chaves (1986), and its petrography with geochemistry were summarized by Kussmaul (1987). The pluton, originally called "Formación granito-gabro de Guacimal", consists of three predominant rock types: granite (leucogranite, porphyritic granite and granophyric granite), monzodiorite, and gabbro. The emplacement of the Guacimal Pluton was followed by extensive hydrothermal alteration and associated mineralization of the Costa Rican Gold Belt (Cigolini and Chaves 1986).

The Guacimal Pluton forms an oval-shaped body, strongly elongated in the NW-SE direction; its length is $\sim 15 \mathrm{~km}$ and the width varies between 4 and $6 \mathrm{~km}$. The NE contact is situated near San Luis, whereas its SE contact is located E of San Martín Norte and Bajo Caliente on the San Lorenzo map sheet (Fig. 2b). The exposed surface of the pluton does not exceed $60-70 \mathrm{~km}^{2}$, although previous workers described a much larger extent of up to $200 \mathrm{~km}^{2}$ (e.g., Kussmaul 1987). Nevertheless, the Guacimal Pluton still represents the largest plutonic body in the NW Costa Rica. Fresh rocks are mainly found in the river valleys (Guacimal and Aranjuez) as well as in numerous streams. However, most of the pluton surface is deeply weathered, forming sandy to loamy eluvia of conspicuously light colour (see Fig. 3a-d).

The pluton intruded into the mafic volcanic rocks of the Aguacate Group and is surrounded by a large metasomatic aureole, which is nearly continuous. The metasomatic rocks, derived from basalts, basaltic andesites and volcaniclastics of the Aguacate Group have their primary textures only rarely preserved. However, frequently they are completely recrystallized showing both secondary structures and mineral assemblages. Characteristic rocks of the metasomatic aureole are greenish to black, very fine-grained to massive hornfelses (cornubianitas in Spanish) with conchoidal fracture. They consist of epidote, clinopyroxene, K-feldspar, plagioclase, wollastonite, grossular-andradite, quartz, calcite and pyrite. Hence, they represent a typical Ca-rich contact metasomatic assemblage. Similar to other occurrences associated with the granitic intrusions of the Cordillera de Talamanca (Drummond et al 1995; Kussmaul 2006; 

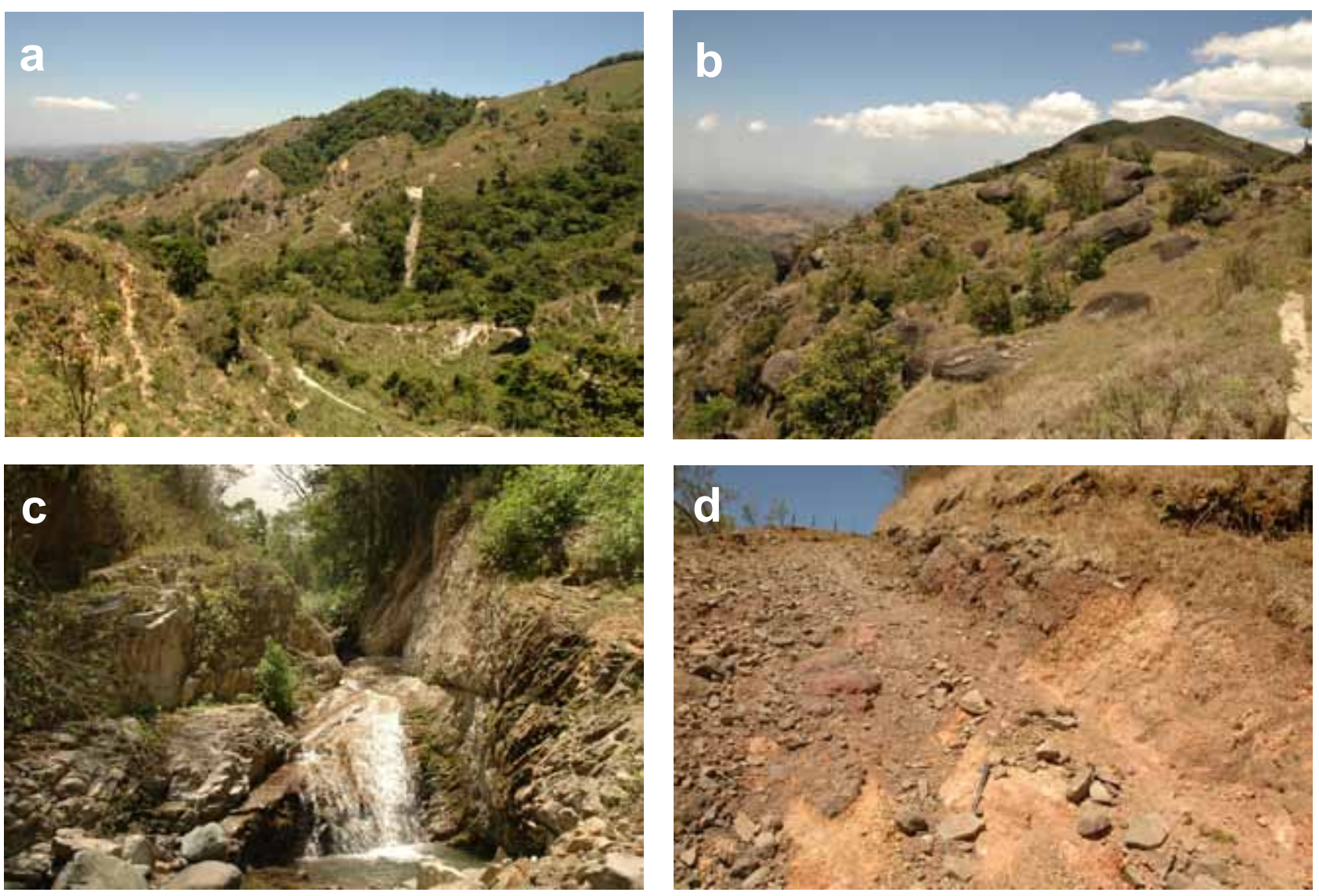

Fig. 3 Field appearance and mode of weathering of the Guacimal Pluton. a - Morphology of the Guacimal Pluton outcrops in its central part, between Cerro San Antonio and Cerro Ojo de Agua. Deep whitish granite eluvia are uncovered by numerous shallow landslides promoted by deforestation and subsequent extensive pasture. $\mathbf{b}$ - Residual granite blocks on the mountain crest $1 \mathrm{~km}$ E of the Cerro San Antonio (sampling locality Ju311). c - Granite exposure in a creek near San Martín Norte (sampling point Ju346). d - The contact of deeply weathered granite with overlaying younger andesite lava of the Pleistocene Monteverde Formation. Occasional road south of the Cerro San Antonio. The photographs in this plate and also in Figs $4-5$ and 8-10 were taken by Vladimír Žáček.

Ulloa and Delgado 2010), metasomatic rims rich in epidote can be observed.

The southern or south-eastern contact of the pluton has a tectonic character and follows an important NW-SE trending fault zone (up to $1 \mathrm{~km}$ wide "El Encanto" fault system) associated with intense hydrothermal alteration, mainly silicification, which is younger than the contact metasomatic aureole. A small portion of the pluton and much of its metasomatic aureole close to its N and NE limits are covered by Early Pleistocene Monteverde lava platform (Fig. 3d) and by large Late Quaternary debris flows and landslides.

\section{Petrology and mineral chemistry}

\subsection{Granitic rocks}

The dominant rocks of the Guacimal Pluton are light, whitish or pinkish monzogranites to granodiorites with variable, but generally low amounts of amphibole, brown biotite and secondary epidote (Fig. 4a-d). Majority of these granites are leucogranites as the amount of mafic minerals is mostly varying between 2 and 5 vol. \%. The individual samples are characterized by similar modal and mineral composition but can show slightly different textures. The granites are mostly medium-grained, weakly porphyritic to equigranular, without any preferred mineral orientation. The size of phenocrysts rarely exceeds $5 \mathrm{~mm}$; granophyric (micrographic) intergrowths are frequent. Most of the samples contain abundant miarolitic cavities, $0.5-4 \mathrm{~mm}$ across, filled by a variety of secondary minerals (Figs $5 \mathrm{a}-\mathrm{f}, 6$ ).

The dominant primary minerals are quartz, plagioclase, and K-feldspar with subordinate biotite, amphibole (magnesiohornblende to edenite), and magnetite. Pargasite, orthopyroxene, Mn-ilmenite, titanite I, rutile, apatite, zircon, thorite, and chalcopyrite (primary inclusions) are the typical accessory phases. Presence of accessory tourmaline, mentioned by Kussmaul 

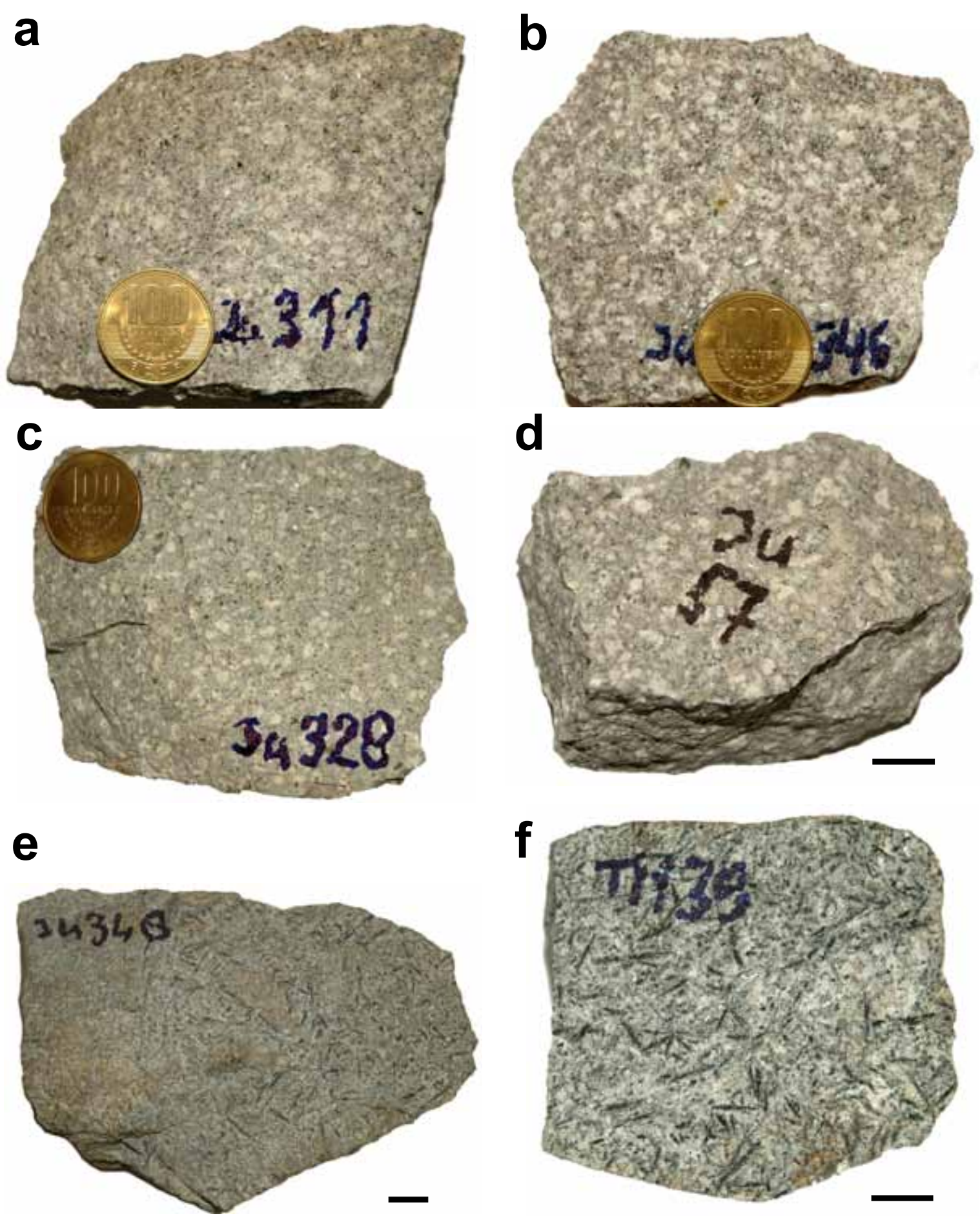

Fig. 4 Hand specimens of the granites and quartz diorite. The granites show a similar appearance, white spots correspond to plagioclase phenocrysts, the greyish or pinkish groundmass is formed by fine K-feldspar and quartz. Observed are tiny dark prismatic amphibole and/or biotite crystals as well as locally green accumulations of secondary minerals with dominant epidote filling miarolitic cavities. Compare related microphotographs (Figs 5 and 8). a - Whitish to pinkish, medium-grained granite with amphibole and Mg-biotite from the central part of the pluton. The material was obtained from a residual block near Cerro San Antonio (see Fig 3b). b - Whitish to pinkish medium-grained leucogranite with scarce amphibole and biotite from the exposure at San Martín Norte (see Fig. 3c). $\mathbf{c}$ - Whitish to greyish, slightly porphyritic amphibole granite with scarce phenocrysts of plagioclase up to $2 \mathrm{~mm}$ long. The sample comes from rock exposure at the bridge near the village of San Luis (sampling point Ju328). d-Greyish micrographic granite (granophyre) sampled in the village of Guacimal from a big isolated block (c. $4 \mathrm{~m})$ transported most probably by river (sampling point Ju57). e - Quartz diorite with conspicuous phenocrysts of amphibole from the dyke 3-5 $\mathrm{m}$ thick penetrating hornfels at the road from Guaria to San Luis (sampling point Ju348). f - The same rock with well preserved prismatic amphibole from the boulder sampled in the Alto Aranjuecito River. The diameter of the coin is $3 \mathrm{~cm}$, the bar corresponds to $1 \mathrm{~cm}$. 

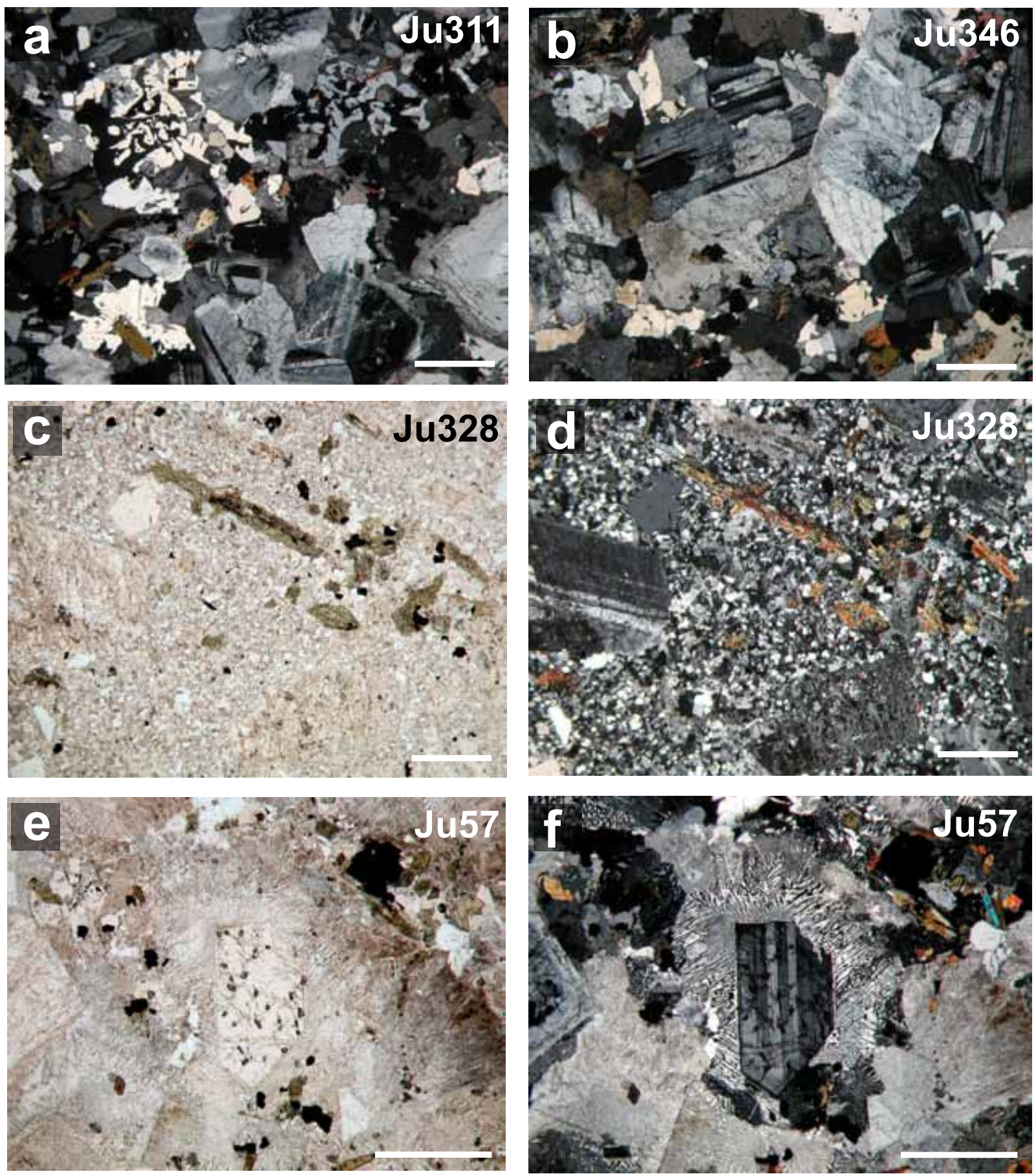

Fig. 5 Photomicrographs of the studied granites (crossed polarizers if not specified otherwise). a - Medium-grained granite with biotite and amphibole (Ju311). The phenocrysts of plagioclase show fine oscillatory zoning and reach the size of $2-6 \mathrm{~mm}$, but the matrix is also relatively coarse grained $(0.1-1 \mathrm{~mm})$. Micrographic intergrowths are locally observed. The rock contains brown biotite and pale-brown amphibole up to $3 \mathrm{~mm}$ long. Occasional small miarolitic cavities are filled with secondary chlorite and epidote. $\mathbf{b}$ - Medium-grained porphyritic granite with biotite, locally showing micrographic structure. The plagioclase phenocrysts (or their clusters) are up to $5 \mathrm{~mm}$ across, matrix is also relatively coarse grained $(0.5-1 \mathrm{~mm})$. Abundant are tiny miarolitic cavities filled by euhedral secondary minerals. c - Porphyritic granite with amphibole (Ju328), the size of the phenocrysts reaches $0.5-2 \mathrm{~mm}$. Relatively abundant brown amphibole forms long-prismatic phenocrysts up to $3 \mathrm{~mm}$ long. Prevailing matrix $(c .60 \%)$ is fine-grained $(0.05-0.2 \mathrm{~mm})$. Plane polarized light. $\mathbf{d}$ - The same sample, crossed polarizers. $\mathbf{e}$ - Porphyritic medium-grained granite (granophyre) with phenocrysts of plagioclase up to $5 \mathrm{~mm}$ long (Ju57). Very fine micrographic (granophyric) intergrowths of quartz and $\mathrm{K}$-feldspar are seen. The rock contains prismatic brown amphibole up to $2 \mathrm{~mm}$ long. Biotite, if originally present, was completely chloritized. Abundant miarolitic cavities are filled by euhedral epidote, actinolite and chlorite. Plane polarized light. f - The same sample, crossed polarizers. The white bar in each photomicrograph is $1 \mathrm{~mm}$ long. 

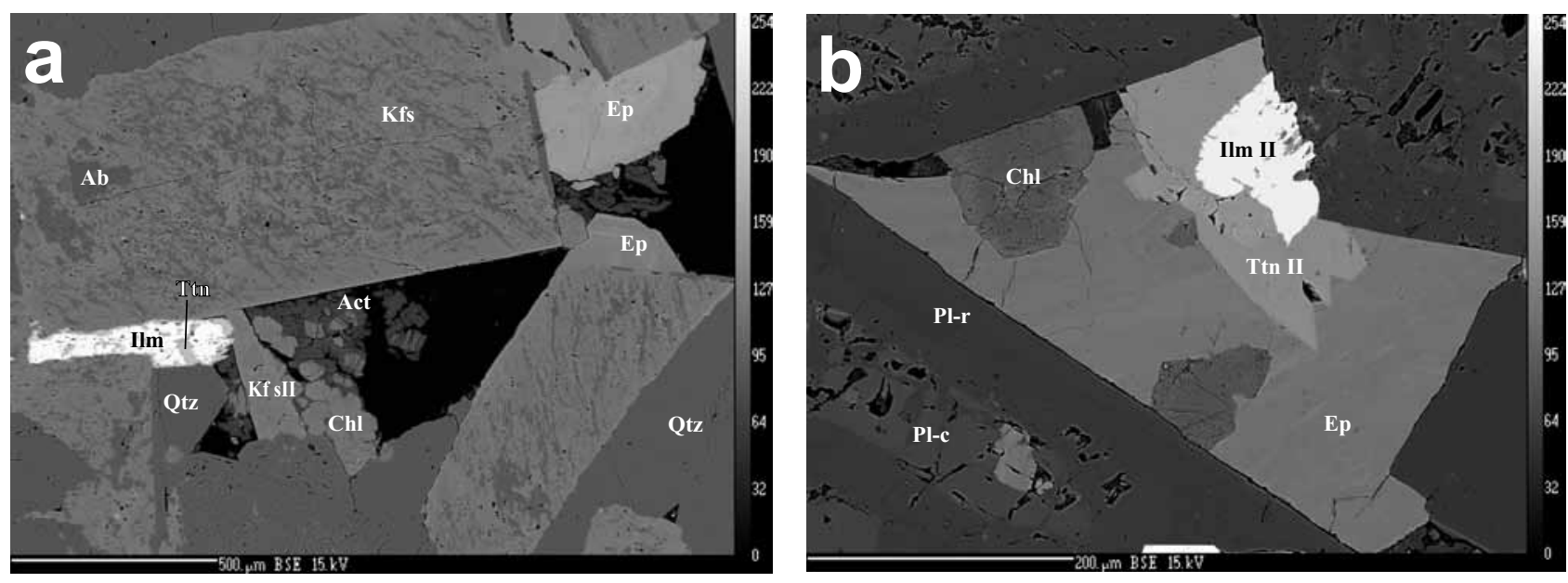

Fig. 6 Back-scattered electron (BSE) images of miarolitic cavities in the Guacimal granites. a - Miarolitic cavity in the sample Ju363 filled by Kfeldspar II (adularia, Kfs II), chlorite (Chl), epidote (Ep) and hornblende II (Act). Other groundmass minerals are K-feldspar (Kfs I), albite (Ab), quartz (Qtz), ilmenite (Ilm) and titanite (Ttn). b - Miarolitic cavity in the sample Ju328 filled by clearly secondary ilmenite II, titanite II, chlorite and epidote (for symbols see Fig. 9a). Note calcic cores (Pl-c) and sodic rims (Pl-r) of the large crystals of plagioclase. Photomicrographs by Radek Škoda.

(1987), was not confirmed. Among mafic minerals, amphibole mostly prevails over biotite. In the sample Ju311, two generations of plagioclase were observed: (1) a single oval xenocryst $5 \mathrm{~mm}$ across with numerous anhedral inclusions of edenite (up to $150 \mu \mathrm{m}$ long) and scarce orthopyroxene (up to $20 \mu \mathrm{m}$ long, always rimmed by edenite) in the centre of the xenocryst, and (2) predominant prismatic plagioclase. The xenocryst was probably not in equilibrium with other minerals in the groundmass and it probably represents a relic of a crystal captured from a more basic magma

The amphibole in the groundmass is brown to pale brown, slightly pleochroic. It forms euhedral to subhedral, mostly prismatic crystals up to $3 \mathrm{~mm}$ long. Its amount can reach up to $\sim 5$ vol. \%. Locally, it is partially replaced by pale brown secondary actinolite or chlorite. Biotite is brown, strongly pleochroic, subhedral, reaching $2 \mathrm{~mm}$ across but mostly smaller. It accounts for up to $\sim 4$ vol. $\%$ but in some samples it is completely lacking. Biotite is more or less (sometimes completely) chloritized. Magnetite is ubiquitous, occurring as euhedral to anhedral equant grains up to $0.5 \mathrm{~mm}$ in diameter, amounting to $0.5-2$ vol. \%. Titanite I forms subhedral grains up to $200 \mu \mathrm{m}$ long in the interstitial space among the primary minerals. Secondary minerals, which either replace mafic primary phases or occur as euhedral crystals in miarolitic cavities and interstitial space in the groundmass, are quartz II, K-feldspar II (adularia), epidote, chlorite, amphibole II (actinolite), ilmenite II and titanite II. Epidote is the most abundant secondary mineral, forming yellow-green euhedral (prismatic to acicular) crystals up to $2 \mathrm{~mm}$ long in the miarolitic cavities. Alternatively it can be microscopic, occurring as clusters of subhedral crystals replacing plagioclase in the matrix. Ilmenite II occurs as rosette-like aggregates up to $100 \mu \mathrm{m}$ long grown in miarolitic cavities as the oldest phase. Titanite II occurs either as euhedral crystals in miarolitic cavities or as rims of ilmenite II.

Chemical composition of rock-forming minerals was analyzed by electron microprobe in samples Ju311, Ju328 and Ju346 (Tab 2, Appendix 1-6) and it is illustrated in Fig. 7.

Plagioclase is labradorite to andesine (rarely albite) with calcic centres and more sodic rims $\left(\mathrm{An}_{58-04}\right)$, poor in $\mathrm{SrO}(<0.20$ wt. \%) and $\mathrm{BaO}(<0.19$ wt. \%) but with increased $\mathrm{K}_{2} \mathrm{O}$ contents $(0.13-0.97$ wt. \%). Rare xenocryst of plagioclase in the sample Ju311 shows discontinuous zoning with small core strongly enriched in $\mathrm{Ca}\left(\mathrm{An}_{86}\right)$ and a wide oscillatory-zoned rim $\left(\mathrm{An}_{48-13}\right)$, with a gap between $\mathrm{An}_{30}$ and $\mathrm{An}_{21}$. In addition, inclusions of edenite and orthopyroxene occur in the calcic centre.

$K$-feldspar contains sharply bound domains rich in $\mathrm{BaO}$ (4.2-5.6 wt. \%); outside of these domains the concentration of $\mathrm{BaO}$ ranges between 0.16 and 1.29 wt. \%, whereas the $\mathrm{Na}_{2} \mathrm{O}$ content is $1.70-3.83$ wt. \%. The $K$-feldspar from miarolitic cavities is both $\mathrm{Na}$ - and $\mathrm{Ba}-$ poor (1.40 wt. $\% \mathrm{Na}_{2} \mathrm{O}$ and 0.72 wt. $\left.\% \mathrm{BaO}\right)$.

$\mathrm{Mg}$-rich biotite $\left(X_{\mathrm{Mg}}=\right.$ molar $\mathrm{Mg} /(\mathrm{Mg}+\mathrm{Fe})$ ratio $=0.66-0.75)$ is rich in $\mathrm{TiO}_{2}(2.92-5.43$ wt. \%) and $\mathrm{F}$ (1.55-2.40 wt. \%) with high Cl concentrations (0.31-0.40 wt. \%). Primary amphibole I corresponds to magnesiohornblende, less frequently to edenite $(\mathrm{Si}=6.96-7.46$ apfu, $\left.(\mathrm{Na}+\mathrm{K})_{\mathrm{A}} \sim 0.3-0.6 \mathrm{apfu}, X_{\mathrm{Mg}}=0.67-0.78\right)$ whereas fibrous secondary amphibole II is actinolite ( $\mathrm{Si}$ $\left.=7.72-7.78 \mathrm{apfu}, X_{\mathrm{Mg}}=0.80\right)$. Amphibole occurring as inclusions together with orthopyroxene in the plagioclase (sample Ju311) is edenite $\left(\mathrm{Si}=6.91\right.$ apfu, $(\mathrm{Na}+\mathrm{K})_{\mathrm{A}}=$ 0.66 apfu, $X_{\mathrm{Mg}}=0.70$ ). 
Tab 2 Chemical composition of amphiboles (wt. \%, apfu) and Hbl-Pl geothermobarometry

\begin{tabular}{|c|c|c|c|c|c|c|c|c|c|c|}
\hline $\begin{array}{l}\text { sample } \\
\text { rock } \\
\text { comment }\end{array}$ & $\begin{array}{c}\text { JU } 346 \\
\text { granite } \\
\text { secondary }\end{array}$ & $\begin{array}{l}\text { JU } 328 \\
\text { granite } \\
\text { primary }\end{array}$ & $\begin{array}{l}\text { JU } 328 \\
\text { granite } \\
\text { primary }\end{array}$ & $\begin{array}{c}\text { JU } 328 \\
\text { granite } \\
\text { secondary }\end{array}$ & $\begin{array}{c}\text { JU } 311 \\
\text { granite } \\
\text { primary }\end{array}$ & $\begin{array}{l}\text { JU } 311 \\
\text { granite } \\
\text { primary }\end{array}$ & $\begin{array}{c}\text { JU } 311 \\
\text { granite } \\
\text { primary }\end{array}$ & $\begin{array}{c}\text { JU } 348 \\
\text { diorite } \\
\text { primary* }\end{array}$ & $\begin{array}{c}\text { JU } 348 \\
\text { diorite } \\
\text { secondary }\end{array}$ & $\begin{array}{c}\text { JU } 348 \\
\text { diorite } \\
\text { secondary }\end{array}$ \\
\hline $\mathrm{SiO}_{2}$ & 52.18 & 47.92 & 48.09 & 54.80 & 46.51 & 46.89 & 46.95 & 41.12 & 48.60 & 53.55 \\
\hline $\mathrm{TiO}_{2}$ & 0.61 & 1.63 & 1.46 & 0.08 & 1.60 & 1.65 & 1.62 & 2.30 & 1.29 & 0.35 \\
\hline $\mathrm{Al}_{2} \mathrm{O}_{3}$ & 3.57 & 6.13 & 5.83 & 1.72 & 6.36 & 6.44 & 6.19 & 12.22 & 5.90 & 2.66 \\
\hline $\mathrm{Fe}_{2} \mathrm{O}_{3}$ calc & 1.84 & 2.57 & 2.95 & 1.91 & 0.70 & 1.02 & 2.10 & 6.87 & 2.86 & 2.10 \\
\hline $\mathrm{FeO}^{\text {calc }}$ & 7.38 & 9.83 & 9.71 & 6.36 & 11.78 & 11.21 & 10.34 & 5.51 & 7.52 & 6.44 \\
\hline $\mathrm{MnO}$ & 0.75 & 0.43 & 0.50 & 0.64 & 0.54 & 0.43 & 0.45 & 0.18 & 0.40 & 0.33 \\
\hline $\mathrm{CaO}$ & 11.42 & 11.50 & 11.72 & 12.64 & 11.16 & 11.28 & 11.28 & 11.55 & 11.85 & 12.28 \\
\hline $\mathrm{Na}_{2} \mathrm{O}$ & 1.76 & 1.61 & 1.44 & 0.60 & 2.14 & 1.96 & 1.40 & 2.51 & 1.17 & 0.48 \\
\hline $\mathrm{K}_{2} \mathrm{O}$ & 0.50 & 0.54 & 0.47 & 0.12 & 0.59 & 0.55 & 0.57 & 0.46 & 0.63 & 0.23 \\
\hline $\mathrm{F}$ & 2.10 & 0.81 & 0.82 & 0.72 & 1.82 & 1.40 & 0.82 & 0.90 & 0.63 & 0.49 \\
\hline $\mathrm{Cl}$ & 0.12 & 0.13 & 0.12 & 0.04 & 0.14 & 0.15 & 0.16 & 0.00 & 0.19 & 0.17 \\
\hline $\mathrm{H}_{2} \mathrm{O}_{\text {calc }}$ & 1.07 & 1.62 & 1.61 & 1.76 & 1.12 & 1.33 & 1.59 & 1.58 & 1.72 & 1.83 \\
\hline Total & 99.94 & 96.10 & 97.62 & 98.00 & 98.59 & 98.64 & 97.25 & 97.25 & 97.97 & 98.01 \\
\hline \multicolumn{11}{|c|}{ Formula after Holland and Blundy (1994) assuming $24 \mathrm{O}+\mathrm{OH}+\mathrm{F}+\mathrm{Cl})$ and $\mathrm{OH}+\mathrm{F}+\mathrm{Cl}=2$} \\
\hline $\mathrm{Si}$ & 7.435 & 6.994 & 7.050 & 7.749 & 6.901 & 6.897 & 6.934 & 6.053 & 7.015 & 7.571 \\
\hline $\mathrm{Al} l^{\mathrm{iv}}$ & 0.565 & 1.006 & 0.950 & 0.251 & 1.099 & 1.103 & 1.066 & 1.947 & 0.985 & 0.429 \\
\hline Sum T & 8.000 & 8.000 & 8.000 & 8.000 & 8.000 & 8.000 & 8.000 & 8.000 & 8.000 & 8.000 \\
\hline $\mathrm{Al}^{\mathrm{vi}}$ & 0.035 & 0.050 & 0.057 & 0.036 & 0.014 & 0.013 & 0.012 & 0.172 & 0.019 & 0.015 \\
\hline $\mathrm{Ti}$ & 0.065 & 0.179 & 0.160 & 0.008 & 0.178 & 0.183 & 0.179 & 0.254 & 0.140 & 0.037 \\
\hline $\mathrm{Fe}^{3+}$ & 0.197 & 0.283 & 0.325 & 0.203 & 0.078 & 0.113 & 0.233 & 0.761 & 0.311 & 0.224 \\
\hline $\mathrm{Mg}$ & 3.801 & 3.317 & 3.239 & 3.915 & 3.388 & 3.457 & 3.433 & 3.143 & 3.706 & 4.034 \\
\hline $\mathrm{Mn}$ & 0.091 & 0.053 & 0.062 & 0.077 & 0.067 & 0.053 & 0.056 & 0.022 & 0.049 & 0.040 \\
\hline $\mathrm{Fe}^{2+}$ & 0.811 & 1.119 & 1.156 & 0.752 & 1.275 & 1.181 & 1.087 & 0.647 & 0.776 & 0.650 \\
\hline Sum M1, 2, 3 & 5.000 & 5.000 & 5.000 & 5.000 & 5.000 & 5.000 & 5.000 & 5.000 & 5.000 & 5.000 \\
\hline $\mathrm{Fe}$ & 0.068 & 0.081 & 0.035 & 0.000 & 0.187 & 0.198 & 0.191 & 0.030 & 0.133 & 0.112 \\
\hline $\mathrm{Ca}$ & 1.744 & 1.799 & 1.841 & 1.906 & 1.775 & 1.777 & 1.786 & 1.821 & 1.833 & 1.860 \\
\hline $\mathrm{Na}$ & 0.188 & 0.120 & 0.125 & 0.094 & 0.038 & 0.025 & 0.023 & 0.148 & 0.035 & 0.029 \\
\hline $\mathrm{K}$ & 0.091 & 0.100 & 0.087 & 0.022 & 0.111 & 0.103 & 0.107 & 0.087 & 0.116 & 0.042 \\
\hline Sum A & 0.390 & 0.436 & 0.372 & 0.091 & 0.689 & 0.636 & 0.485 & 0.654 & 0.410 & 0.144 \\
\hline $\mathrm{OH}$ & 1.023 & 1.590 & 1.586 & 1.665 & 1.108 & 1.309 & 1.576 & 1.576 & 1.665 & 1.739 \\
\hline $\mathrm{F}$ & 0.948 & 0.378 & 0.384 & 0.325 & 0.857 & 0.653 & 0.385 & 0.425 & 0.289 & 0.221 \\
\hline $\mathrm{Cl}$ & 0.029 & 0.032 & 0.030 & 0.010 & 0.035 & 0.038 & 0.039 & 0.000 & 0.046 & 0.040 \\
\hline Sum OH-site & 2.000 & 2.000 & 2.000 & 2.000 & 2.000 & 2.000 & 2.000 & 2.000 & 2.000 & 2.000 \\
\hline Sum cations & 15.390 & 15.436 & 15.372 & 15.091 & 15.689 & 15.636 & 15.485 & 15.654 & 15.410 & 15.144 \\
\hline $\mathrm{Mg} /\left(\mathrm{Mg}+\mathrm{Fe}^{2+}\right)$ & 0.760 & 0.663 & 0.648 & 0.783 & 0.678 & 0.691 & 0.687 & 0.629 & 0.741 & 0.807 \\
\hline $\mathrm{Fe}^{3+} /\left(\mathrm{Fe}^{2+}+\mathrm{Fe}^{3+}\right)$ & 0.183 & 0.191 & 0.214 & 0.213 & 0.051 & 0.076 & 0.154 & 0.529 & 0.255 & 0.227 \\
\hline $\mathrm{Al}^{\mathrm{tot}}$ & 0.599 & 1.055 & 1.007 & 0.287 & 1.112 & 1.117 & 1.078 & 2.120 & 1.004 & 0.444 \\
\hline $\mathrm{XAb}$ & & 0.602 & 0.564 & & 0.442 & 0.403 & 0.452 & & & \\
\hline XAn & & 0.351 & 0.398 & & 0.536 & 0.580 & 0.528 & & & \\
\hline
\end{tabular}

T and P results based on Anderson's spreadsheet for Hbl-Pl thermobarometry (Anderson 1996) using Holland and Blundy (1994) Hbl-Pl thermometry calibration for the reaction: edenite + albite $=$ richterite + anorthite. T Otten - temperatures based on Ti in amphibole following Otten (1984)

\begin{tabular}{|c|c|c|c|c|c|c|}
\hline $\mathrm{T}(\mathrm{AS})\left({ }^{\circ} \mathrm{C}\right)$ & 763 & 769 & 784 & 762 & 720 & \\
\hline P (AS) (kbar) & 0.9 & 0.7 & 0.8 & 1.2 & 1.7 & \\
\hline T Otten $\left({ }^{\circ} \mathrm{C}\right)$ & 760 & 738 & 760 & 765 & 761 & 851 \\
\hline \multicolumn{7}{|c|}{ T, $\mathbf{P}$ and $\mathbf{f O}_{2}$ results calculated by spreadsheet of Ridolfi et al. (2010) } \\
\hline $\mathrm{T}\left({ }^{\circ} \mathrm{C}\right)$ & 802 & 791 & 855 & 857 & 842 & 984 \\
\hline uncertainty & 22 & 22 & 22 & 22 & 22 & 22 \\
\hline $\mathrm{P}$ (kbar) & 0.87 & 0.81 & 0.93 & 0.93 & 0.88 & 4.01 \\
\hline uncertainty & 0.10 & 0.09 & 0.10 & 0.10 & 0.10 & 0.44 \\
\hline depth $(\mathrm{km})$ & 3.3 & 3.1 & 3.5 & 3.5 & 3.3 & 15.2 \\
\hline$\Delta \mathrm{NNO}$ & 1.6 & 1.6 & 1.9 & 2.0 & 2.1 & 1.0 \\
\hline $\log \mathrm{fO}_{2}$ & -12.2 & -12.5 & -10.9 & -10.7 & -10.9 & -9.5 \\
\hline uncertainty & 0.4 & 0.4 & 0.4 & 0.4 & 0.4 & 0.4 \\
\hline
\end{tabular}

* the composition used for geochemical modelling 

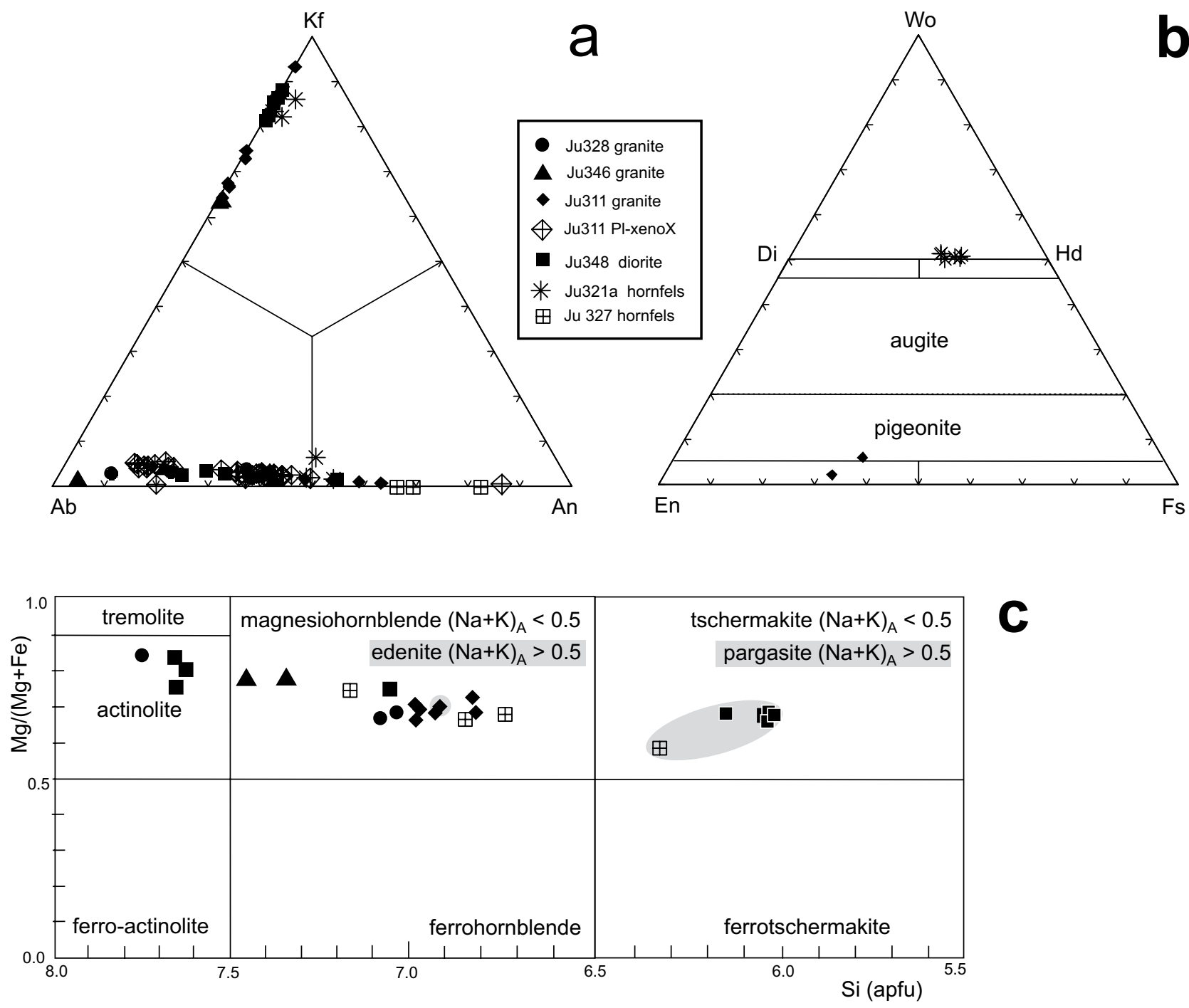

d
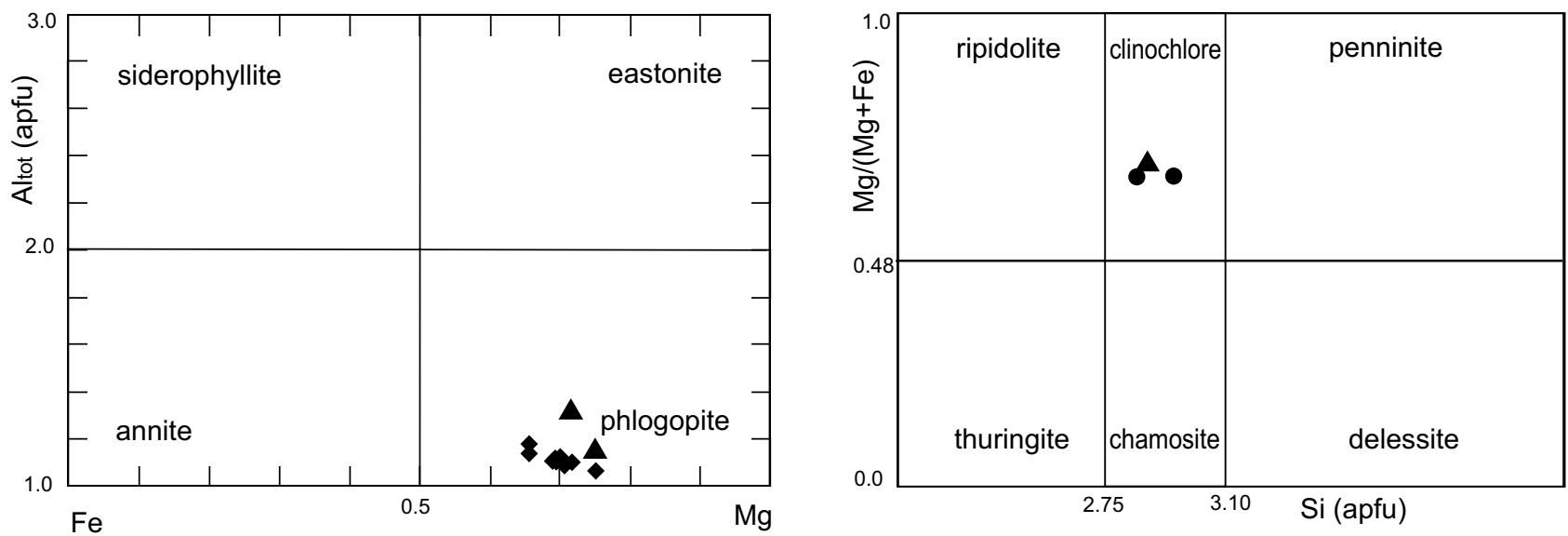

Fig. 7 Chemical composition of feldspars, pyroxenes, hornblende, dark mica and chlorite from granitic rocks and hornfelses. $\mathbf{a}-\mathrm{Ab}-\mathrm{Kfs}-\mathrm{An}$ plot for feldspars. $\mathbf{b}-$ En-Fs-Wo plot for pyroxenes. $\mathbf{c}-$ The diagram for calcic amphiboles characterized by the following site occupancies: $\mathrm{Ca}_{\mathrm{B}}>1.5, \mathrm{Ca}_{\mathrm{A}}$ $<0.5, \mathrm{Ti}<0.50$ and $(\mathrm{Na}+\mathrm{K})_{\mathrm{A}}<0.5 \mathrm{apfu}$, only the shaded compositions correspond to amphiboles with $(\mathrm{Na}+\mathrm{K})_{\mathrm{A}}>0.5$ apfu (calculated on the basis of 24 $(\mathrm{O}+\mathrm{OH}+\mathrm{F})$, assuming $\mathrm{OH}+\mathrm{F}=2$, following Leake at al. 1997). $\mathbf{d}-\mathrm{Mg} /(\mathrm{Mg}+\mathrm{Fe}) \mathrm{vs}$. Al ${ }^{\text {tot }}$ plot (apfu) of dark mica (calculated on the basis of 12 $(\mathrm{O}+\mathrm{OH}+\mathrm{F}+\mathrm{Cl})$, assuming $\mathrm{OH}+\mathrm{F}+\mathrm{Cl}=2)$. e $-\mathrm{Si}$ vs. $\mathrm{Mg} /(\mathrm{Mg}+\mathrm{Fe})$ plot for chlorites (calculated on the basis of $18(\mathrm{O}+\mathrm{OH})$, assuming $8 \mathrm{OH})$. 
Orthopyroxene is Fe-rich enstatite $\left(X_{\mathrm{Mg}}=0.62-0.67\right)$ with increased $\mathrm{Al}_{2} \mathrm{O}_{3}(0.51-2.02$ wt. \%) and $\mathrm{CaO}$ concentrations (0.92-2.68 wt. \%). Magnetite is relatively poor in minor elements: $0.24-1.18$ wt. $\% \mathrm{TiO}_{2}, 0.13-1.65$ wt. $\% \mathrm{Al}_{2} \mathrm{O}_{3}, 0.27-0.68$ wt. $\% \mathrm{~V}_{2} \mathrm{O}_{3}$. A small inclusion of chalcopyrite was found enclosed in magnetite. Relatively abundant accessories are apatite and zircon. Thorite up to $3 \mu \mathrm{m}$ across is very rare. Ilmenite forms (1) individual poikilitic aggregates intergrown with apatite, (2) thin exsolution lamellae in magnetite, or (3) crystallized in miarolitic cavities as the oldest secondary phase. All types of ilmenite are rich in $\mathrm{MnO}$ (8-21 wt. \%), which corresponds to $17-44 \mathrm{~mol}$ \% of the pyrophanite component; the highest $\mathrm{Mn}$ concentrations were found in the exsolution lamellae. Titanite I found in the rock matrix is poor in $\mathrm{Al}_{2} \mathrm{O}_{3}$ and $\mathrm{F}$, unlike titanite II in the miarolitic cavities and titanite overgrowths on ilmenite with 5.9-8.2 wt. $\% \mathrm{Al}_{2} \mathrm{O}_{3}$ and $2-3$ wt. $\%$ F. Epidote contains 10.5-15.8 wt. \% of $\mathrm{Fe}_{2} \mathrm{O}_{3}{ }^{\text {tot; }}$; chlorite corresponds to clinochlore ( $\left.\mathrm{Si}=2.88-2.95 \mathrm{apfu}, X_{\mathrm{Mg}}=0.65-0.68\right)$; see also Fig. 7.

\subsection{Quartz diorite}

The only quartz diorite sample studied is strongly porphyritic and composed essentially of dominant plagioclase and pale green amphibole II. Minor constituents are brown amphibole I, K-feldspar and quartz; an opaque mineral, epidote, chlorite and titanite are common accessories. Amphibole I, K-feldspar and magnetite are primary phases formed by magmatic crystallization, and were mostly replaced by a mosaic of fine prismatic (probably recrystallized) plagioclase, pale green amphi- bole II and yellowish epidote. Overgrowths of highly aluminous titanite replacing epidote were observed (Figs $4 \mathrm{e}-\mathrm{f}, 8$ ).

Brown amphibole $I$ is titanian pargasite $(\mathrm{Si}=6.05-$ 6.15 apfu, $\left.\mathrm{Ti}=0.26-0.29 \mathrm{apfu}, X_{\mathrm{Mg}}=0.68-0.69\right)$. Primary $K$-feldspar is enriched in $\mathrm{Na}_{2} \mathrm{O}(0.68-1.98$ wt. \%), $\mathrm{BaO}$ (0.82-3.74 wt. \%) and $\mathrm{SrO}(0.08-0.16$ wt. \%). Plagioclase is mostly oligoclase but rarely as calcic as labradorite $\left(\mathrm{An}_{24-62}\right)$ poor in $\mathrm{BaO}(<0.09$ wt. \%) but with slightly increased $\mathrm{K}_{2} \mathrm{O}(0.48-0.64$ wt. \%) and $\mathrm{SrO}$ contents (0.10-0.17 wt. \%). Amphibole II is magnesiohornblende to actinolite $\left(\mathrm{Si}=7.06-7.67 \mathrm{apfu}, X_{\mathrm{Mg}}=0.75-0.83\right)$. Magnetite contains $0.31-0.88$ wt. $\% \mathrm{TiO}_{2}, 0.04$ wt. $\% \mathrm{Al}_{2} \mathrm{O}_{3}$ and 0.49 wt. $\% \mathrm{~V}_{2} \mathrm{O}_{3}$, ilmenite hosts 5.3-8.3 wt. \% $\mathrm{MnO}$, corresponding to $13-18$ mol. \% pyrophanite. Epidote is relatively Fe-rich (11.4-12.7 wt. $\% \mathrm{Fe}_{2} \mathrm{O}_{3}{ }^{\text {tot }}=0.66-0.73$ $\mathrm{Fe}^{3+}$ apfu). Titanite, which is found as overgrowths on epidote, is extremely rich in $\mathrm{Al}_{2} \mathrm{O}_{3}(11.26 \mathrm{wt}$. \%) and $\mathrm{F}$ (3.93 wt. \%).

\section{Country rocks of the Guacimal Pluton}

The Guacimal Pluton is surrounded by thermal aureole several hundred metres to $c$. $1.5 \mathrm{~km}$ wide, which overprints the Aguacate Group country rocks. The exocontact is transitional, with the intensity of thermal effects decreasing gradually away from the contact with granite. The contact aureole is most probably continuous but along the northern contact it is locally hidden below the younger Monteverde Formation. In its SW part, the pluton is truncated by the El Encanto zone (Fig. 2b), a fault system striking NW-SE, which follows the granite
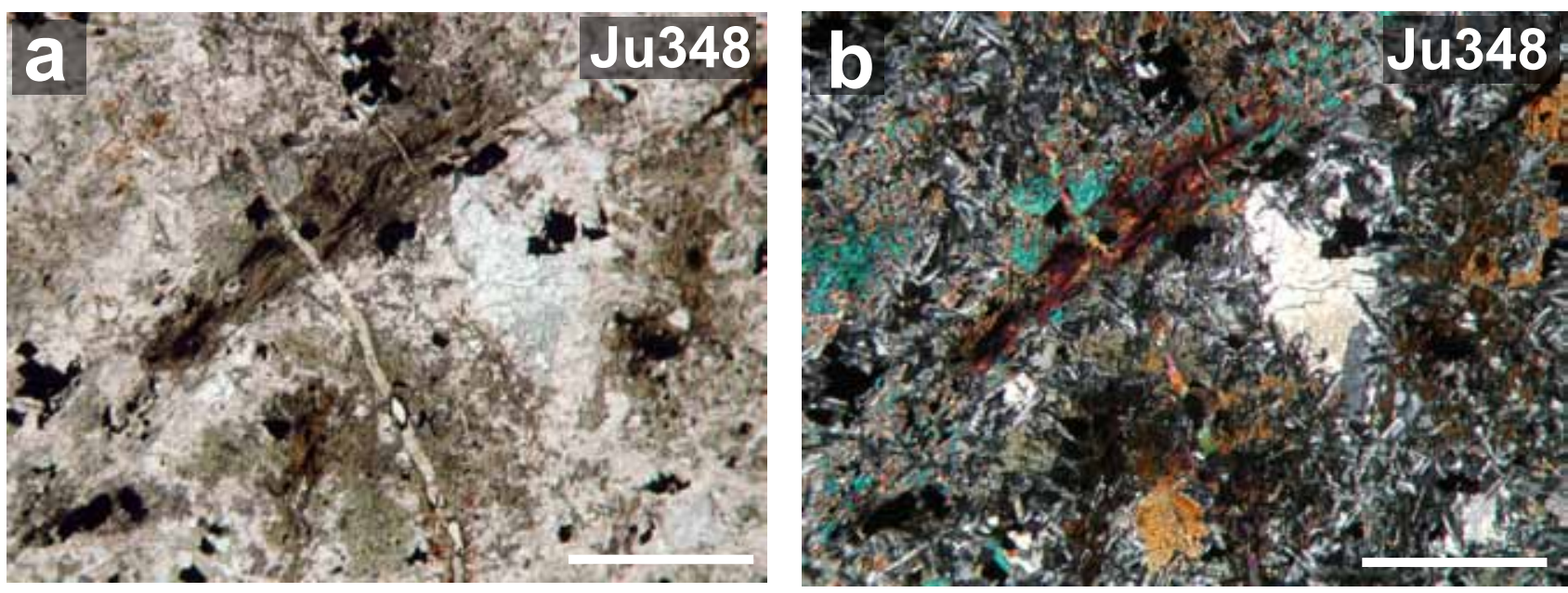

Fig. 8a - Photomicrographs of the quartz diorite sample Ju348 (see also Fig. 4e). Primary mineral assemblage was formed predominantly by prismatic brown amphibole (up to $7 \mathrm{~mm}$ long), plagioclase and some quartz. However, the rock is strongly recrystallized to a fine mosaic of secondary prismatic plagioclase, acicular greenish actinolite with abundant epidote and chlorite, occurring both in the matrix and in veinlets. It is difficult to recognize primary and secondary phases due to cloudy matrix. Plane polarized light. $\mathbf{b}-$ The same sample, crossed polarizers. The bar corresponds to $1 \mathrm{~mm}$. 

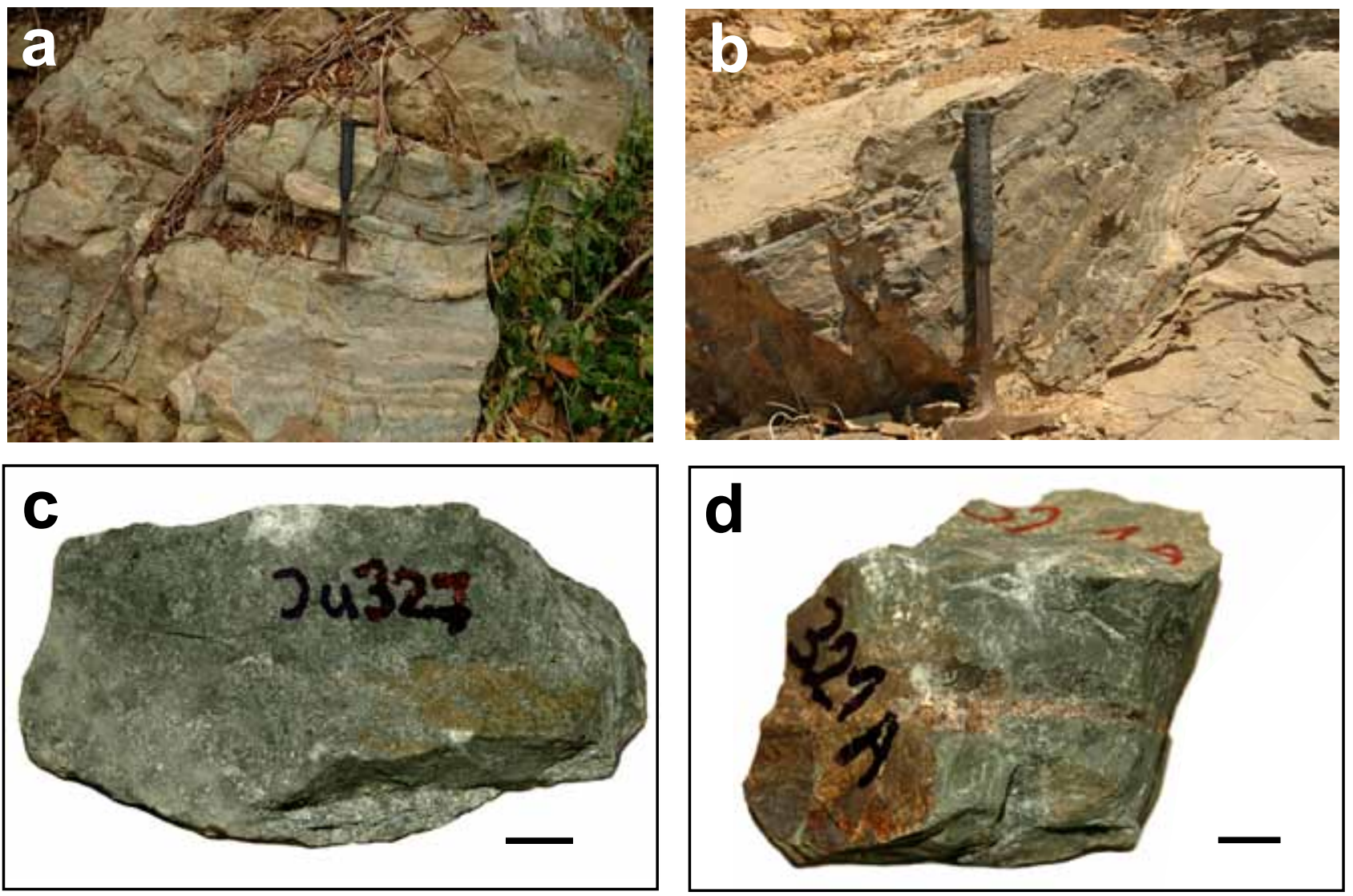

Fig. 9 Field photographs of metasomatic hornfelses from the thermal aureole of the Guacimal Pluton. a - Exposure of greyish-green banded hornfelses at the Guacimal River near San Luis (Ju323). b - Banded and undulated sequence of black fine-grained hornfelses in the metasomatic zone at the road to Bajo Caliente near the El Encanto reservoir dam. c - Sample of medium-grained speckled hornfels composed mainly of clinozoisite-epidote, chlorite, actinolite and calcite from the mountains E of San Luis (Ju327). d - Fine grained hornfels with the veinlet of andradite which represents typical hornfels "cornubianita". North-west of San Luis, sample Ju321a. The bar is $1 \mathrm{~cm}$ long.
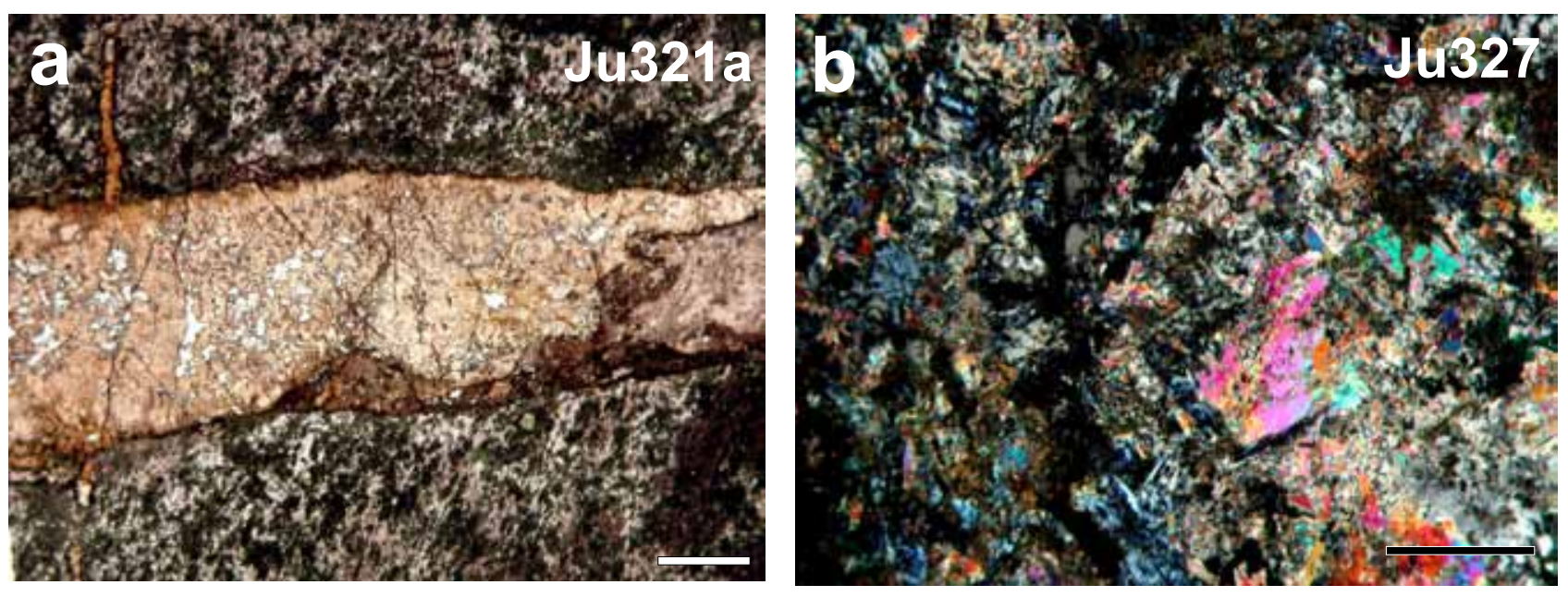

Fig. 10 Photomicrographs of contact metasomatic rocks shown in Figs 9c-d. a - The sample Ju321a with an andradite veinlet. The matrix is composed of fine-grained mosaic with dominant diopside, quartz, wollastonite, K-feldspar and andradite. b - Microstructure of the sample Ju327 formed by prevailing hornblende, clinozoisite-epidote, prehnite and chlorite. Crossed polarizers, bars correspond to $1 \mathrm{~mm}$. 
contact for at least $15 \mathrm{~km}$. This structure is accompanied by intense hydrothermal alteration, mainly silicification with subordinate amounts of pyrophyllite, alunite, sericite, kaolinite, and several other, rather rare minerals (Fig. 2a-b).

Contact metasomatic rocks are highly variable with apple green, dark grey-green to nearly black colour (Fig. 9a-b). Two main types can be distinguished: (1) fine- to medium-grained speckled rocks with relics of primary volcanic structures and magmatic minerals (e.g., former phenocrysts), and (2) very fine-grained hornfelses with conchoidal fracture, where primary minerals and structures were completely obliterated by a newly formed assemblage (Fig. 9c-d). The contact metasomatic rocks can also show bands, several $\mathrm{cm}-\mathrm{dm}$ thick, which differ in colour and grain size. Altered rocks including hornfelses are also characterized by mostly low magnetic susceptibilities $\left(0.1-0.5 \times 10^{-3}\right.$ SI), which indicate that the original magnetic mineral was decomposed.

The coarse-grained contact-metasomatic rocks consist of abundant epidote-clinozoisite and chlorite, with rare accumulations of calcite. The amount of epidote, which is the most characteristic secondary mineral, increases from several up to over $50 \mathrm{vol}$. \%. The calcsilicate hornfelses are very fine-grained with characteristic conchoidal fracture. They contain pyrite (disseminated and veinlets), epidote or, rarely, andradite-rich garnet. The following phases were identified by X-ray diffraction or electron microprobe: Ca-rich garnet, clinozoisite-epidote, plagioclase, hedenbergite, amphibole, K-feldspar, wollastonite, chlorite, prehnite, quartz, calcite, pyrite, titanite, and smectite (see Fig. 10a-b). Mineral chemistry of hornfelses was studied in two samples (Appendix 5-6).

In the sample Ju321a, plagioclase is poorly zoned andesine-labradorite, $\mathrm{An}_{47-53}$ with elevated concentrations of $\mathrm{K}_{2} \mathrm{O}(0.35-1.17$ wt. \%) and FeOt (0.52-0.81 wt. \%). $K$-feldspar contains slightly elevated $\mathrm{Na}_{2} \mathrm{O}$ $(1.15-1.85$ wt. \%) and $\mathrm{BaO}$ contents $(0.37-0.52$ wt. \%). Clinopyroxene is hedenbergite $\left(X_{\mathrm{Mg}}=0.33-0.41\right)$ with $0.74-1.19$ wt. $\% \mathrm{Al}_{2} \mathrm{O}_{3}$ and $0.27-0.31$ wt. $\% \mathrm{Na}_{2} \mathrm{O}$. $\mathrm{Ca}$-rich garnet corresponds to andradite-grossular solution $\left(\mathrm{Grs}_{04-52} \mathrm{Adr}_{44-98} \mathrm{Sps}_{<04}\right)$, poor in oxides of Ti, $\mathrm{Cr}$ and $\mathrm{Mg}($ all $<0.10$ wt. \%). Epidote contains 9.65 wt. $\% \mathrm{Fe}_{2} \mathrm{O}_{3}$ tot.

The sample Ju327 is composed mainly of quartz, amphibole, plagioclase, clinozoisite-epidote, and prehnite. Amphibole corresponds to magnesiohornblende or pargasite ( $\left.\mathrm{Si}=6.34-7.17 \mathrm{apfu}, X_{\mathrm{Mg}}=0.59-0.57\right)$. Plagioclase is labradorite to bytownite $\left(\mathrm{An}_{65-82}\right)$ poor in $\mathrm{BaO}$ and with elevated $\mathrm{SrO}$ (0.04-0.35 wt. \%). Clinozoisite-epidote occurs as several successive generations with the $\mathrm{Fe}_{2} \mathrm{O}_{3}$ tot varying widely between 3.08 and $9.42 \mathrm{wt}$. \%. Prehnite formed as the youngest phase. Accessory titanite is poor in $\mathrm{Al}_{2} \mathrm{O}_{3}(1.72$ wt. \%) and $\mathrm{F}(0.09$ wt. \%).

Tab 3 U-Pb dating

\begin{tabular}{|c|c|c|c|c|c|c|c|c|c|c|c|c|c|}
\hline \multirow[b]{2}{*}{ Analysis } & \multicolumn{9}{|c|}{ ISOTOPIC RATIOS } & \multicolumn{4}{|c|}{ CALCULATED AGES (Ma) } \\
\hline & ${ }^{207} \mathrm{~Pb} /{ }^{235} \mathrm{U}$ & $\pm 1 \sigma$ & ${ }^{206} \mathrm{~Pb} /{ }^{238} \mathrm{U}$ & $\pm 1 \sigma$ & Rho & ${ }^{238} \mathrm{U} /{ }^{206} \mathrm{~Pb}$ & $\pm 1 \sigma$ & ${ }^{207} \mathrm{~Pb} /{ }^{206} \mathrm{~Pb}$ & $\pm 1 \sigma$ & ${ }^{207} \mathrm{~Pb} /{ }^{235} \mathrm{U}$ & $\pm 1 \sigma$ & ${ }^{206} \mathrm{~Pb} /{ }^{238} \mathrm{U}$ & $\pm 1 \sigma$ \\
\hline \multicolumn{14}{|c|}{ Sample JU-311, U-Pb age $6.3 \pm 0.5 \mathrm{Ma}$} \\
\hline$\# 1$ & 0.0184 & 0.0021 & 0.0010 & 0.0001 & 0.31 & 980.4 & 68.6 & 0.1310 & 0.0193 & 18.5 & 2.1 & 6.6 & 0.5 \\
\hline \#2 & 0.0145 & 0.0032 & 0.0010 & 0.0001 & 0.21 & 1016.1 & 93.0 & 0.1070 & 0.0169 & 14.6 & 3.2 & 6.3 & 0.6 \\
\hline \#3 & 0.0161 & 0.0028 & 0.0011 & 0.0001 & 0.28 & 908.1 & 89.6 & 0.1063 & 0.0188 & 16.3 & 2.8 & 7.1 & 0.7 \\
\hline$\# 4$ & 0.0257 & 0.0079 & 0.0012 & 0.0002 & 0.30 & 841.0 & 155.5 & 0.1568 & 0.0344 & 25.8 & 7.8 & 7.7 & 1.4 \\
\hline$\# 5$ & 0.0241 & 0.0037 & 0.0011 & 0.0001 & 0.38 & 931.4 & 110.9 & 0.1627 & 0.0233 & 24.2 & 3.7 & 6.9 & 0.8 \\
\hline \#6 & 0.0193 & 0.0027 & 0.0011 & 0.0001 & 0.31 & 918.3 & 80.7 & 0.1288 & 0.0203 & 19.4 & 2.7 & 7.0 & 0.6 \\
\hline$\# 7$ & 0.0069 & 0.0014 & 0.0011 & 0.0002 & 0.37 & 883.8 & 133.0 & 0.0444 & 0.0080 & 7.0 & 1.4 & 7.3 & 1.1 \\
\hline$\# 8$ & 0.0052 & 0.0020 & 0.0011 & 0.0001 & 0.18 & 930.2 & 124.1 & 0.0352 & 0.0076 & 5.3 & 2.0 & 6.9 & 0.9 \\
\hline \multicolumn{14}{|c|}{ Sample JU-328 } \\
\hline$\# 9$ & 0.0126 & 0.0015 & 0.0013 & 0.0001 & 0.23 & 748.6 & 41.7 & 0.0684 & 0.0081 & 12.7 & 1.5 & 8.6 & 0.5 \\
\hline$\# 10$ & 0.0177 & 0.0045 & 0.0015 & 0.0001 & 0.14 & 683.3 & 48.4 & 0.0878 & 0.0123 & 17.8 & 4.5 & 9.4 & 0.7 \\
\hline \#11 & 0.0104 & 0.0023 & 0.0015 & 0.0001 & 0.13 & 683.2 & 40.9 & 0.0514 & 0.0076 & 10.5 & 2.3 & 9.4 & 0.6 \\
\hline \#12 & 0.0114 & 0.0028 & 0.0011 & 0.0001 & 0.21 & 930.7 & 98.2 & 0.0772 & 0.0144 & 11.5 & 2.9 & 6.9 & 0.7 \\
\hline \#13 & 0.0128 & 0.0027 & 0.0015 & 0.0001 & 0.23 & 687.1 & 65.1 & 0.0637 & 0.0172 & 12.9 & 2.7 & 9.4 & 0.9 \\
\hline \#14 & 0.0063 & 0.0009 & 0.0009 & 0.0001 & 0.27 & 1145.1 & 86.0 & 0.0526 & 0.0066 & 6.4 & 0.9 & 5.6 & 0.4 \\
\hline \multicolumn{14}{|c|}{ Sample JU-346, U-Pb age $6.0 \pm 0.4 \mathrm{Ma}$} \\
\hline$\# 15$ & 0.0131 & 0.0034 & 0.0010 & 0.0001 & 0.16 & 999.5 & 84.7 & 0.0951 & 0.0230 & 13.2 & 3.4 & 6.4 & 0.5 \\
\hline$\# 16$ & 0.0126 & 0.0017 & 0.0009 & 0.0001 & 0.24 & 1066.8 & 71.1 & 0.0977 & 0.0097 & 12.7 & 1.7 & 6.0 & 0.4 \\
\hline$\# 17$ & 0.0073 & 0.0015 & 0.0010 & 0.0001 & 0.17 & 986.0 & 69.9 & 0.0519 & 0.0074 & 7.3 & 1.5 & 6.5 & 0.5 \\
\hline \#18 & 0.0257 & 0.0041 & 0.0011 & 0.0001 & 0.30 & 944.5 & 92.0 & 0.1757 & 0.0249 & 25.7 & 4.1 & 6.8 & 0.7 \\
\hline \#19 & 0.0316 & 0.0071 & 0.0013 & 0.0002 & 0.29 & 790.6 & 102.2 & 0.1810 & 0.0262 & 31.6 & 7.0 & 8.1 & 1.1 \\
\hline$\# 20$ & 0.0419 & 0.0054 & 0.0013 & 0.0001 & 0.34 & 774.5 & 68.2 & 0.2355 & 0.0263 & 41.7 & 5.2 & 8.3 & 0.7 \\
\hline \#21 & 0.0586 & 0.0102 & 0.0015 & 0.0002 & 0.46 & 657.6 & 105.3 & 0.2795 & 0.0374 & 57.8 & 9.8 & 9.8 & 1.6 \\
\hline$\# 22$ & 0.0104 & 0.0023 & 0.0009 & 0.0001 & 0.19 & 1066.1 & 88.4 & 0.0802 & 0.0130 & 10.5 & 2.3 & 6.0 & 0.5 \\
\hline$\# 23$ & 0.0306 & 0.0063 & 0.0011 & 0.0001 & 0.22 & 913.0 & 84.9 & 0.2023 & 0.0299 & 30.6 & 6.3 & 7.1 & 0.7 \\
\hline
\end{tabular}




\section{Thermobarometry and oxybarometry of magmatic crystallization}

The temperature and pressure of magmatic crystallization were assessed using amphibole-plagioclase thermobarometry (Anderson and Smith 1995; Anderson 1996). The temperature and pressure were estimated iteratively by a spreadsheet that was kindly provided by
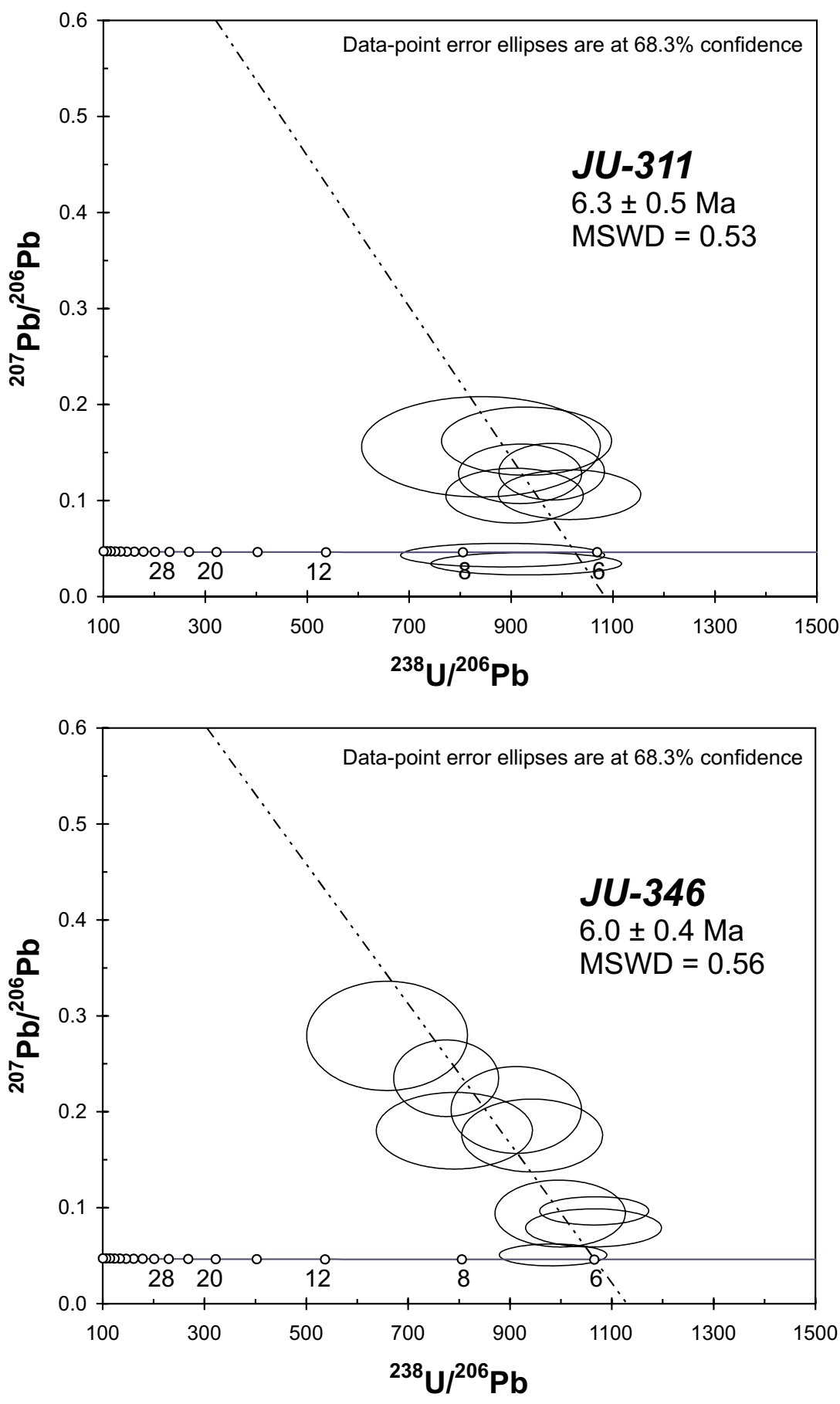

Fig. 11 Inverse concordia diagrams for the samples Ju311 and Ju346.
L. Anderson. The temperature estimates are based on the amphibole-plagioclase thermometric calibration of the reaction edenite + albite $=$ richterite + anorthite $($ Holland and Blundy 1994), and on the Ti solubility in amphibole (Otten 1984). Amphibole equilibria were also used to estimate oxygen fugacity (Ridolfi et al. 2010) (Tab. 2).

The temperatures calculated for five amphibole and plagioclase pairs from the felsic Guacimal suite fall in the interval $720-857^{\circ} \mathrm{C}$ (mostly ranging between 760 and $800^{\circ} \mathrm{C}$ ). The pressures vary between 0.7 and 1.7 kbar with a distinct maximum at $0.8-0.9$ kbar. One sample from the mafic suite yielded temperatures between 851 and $984^{\circ} \mathrm{C}$ and pressure of c. 4 kbar. Oxygen fugacity estimated for the felsic suite is 1.6-2.1 log units above the nickel-nickel oxide buffer (NNO), whereas the estimate for the mafic suite is $\Delta \mathrm{NNO}=+1.0$.

\section{LA ICP-MS zircon age}

Zircon from granite samples Ju311, Ju328 and Ju346 forms prismatic and stubby crystals up to $150 \mu \mathrm{m}$ long. The $\mathrm{CL}$ imaging revealed oscillatory zoning combined with sector zoning, which are both indicative of crystallization from the melt for most of the grains (Corfu et al. 2003). However, some zircon grains, especially in the sample Ju328, also contain discrete domains in their cores that can be interpreted as an older, inherited component.

Results of the LA ICP-MS dating are summarized in Tab. 3 and the data are shown on inverse concordia diagrams in Fig. 11. Most of the data points plot away from the concordia curve suggesting presence of variable amounts of common $\mathrm{Pb}$ in the analysed zircons. Since the accurate correction for common $\mathrm{Pb}$ via measurement of ${ }^{204} \mathrm{~Pb}$ is difficult due to isobaric interference of ${ }^{204} \mathrm{Hg}$ present in the ICP gas, we have used the inverse Tera-Wasserburg projection to calculate $\mathrm{U}-\mathrm{Pb}$ ages for the radiogenic $\mathrm{Pb}$ component. The data regression lines were anchored to common $\mathrm{Pb}$ composition corresponding to the two-stage model of crustal $\mathrm{Pb}$ evolu- 
Tab. 4 Major- and trace-element whole-rock geochemical data

\begin{tabular}{|c|c|c|c|c|c|c|c|c|c|}
\hline $\begin{array}{l}\text { Sample } \\
\text { Rock type }\end{array}$ & $\begin{array}{l}\text { Detection } \\
\text { limit }\end{array}$ & $\begin{array}{l}\text { Ju348 } \\
\text { qtz diorite }\end{array}$ & $\begin{array}{l}\text { Ju98 } \\
\text { granite }\end{array}$ & $\begin{array}{l}\text { Ju328 } \\
\text { granite }\end{array}$ & $\begin{array}{l}\text { Ju57 } \\
\text { granite }\end{array}$ & $\begin{array}{l}\text { Ju311 } \\
\text { granite }\end{array}$ & $\begin{array}{l}\begin{array}{l}\text { Ju346 } \\
\text { granite }\end{array}\end{array}$ & $\begin{array}{l}\text { Ju327 } \\
\text { hornfels }\end{array}$ & $\begin{array}{l}\text { Ju323 } \\
\text { hornfels }\end{array}$ \\
\hline $\mathrm{SiO}_{2}$ & 0.01 & 54.51 & 68.83 & 69.56 & 69.81 & 70.73 & 71.55 & 45.38 & 55.86 \\
\hline $\mathrm{TiO}_{2}^{2}$ & 0.01 & 0.92 & 0.43 & 0.40 & 0.33 & 0.35 & 0.29 & 0.51 & 0.63 \\
\hline $\mathrm{Al}_{2} \mathrm{O}_{3}$ & 0.01 & 16.20 & 14.91 & 14.53 & 14.70 & 14.48 & 14.15 & 14.48 & 13.52 \\
\hline $\mathrm{Fe}_{2} \mathrm{O}_{3} \mathrm{t}$ & 0.04 & 10.04 & 3.02 & 3.18 & 2.66 & 2.59 & 2.26 & 8.78 & 5.01 \\
\hline $\mathrm{MnO}$ & 0.01 & 0.15 & 0.11 & 0.08 & 0.10 & 0.07 & 0.10 & 0.15 & 0.05 \\
\hline $\mathrm{MgO}$ & 0.01 & 4.14 & 0.77 & 0.85 & 0.78 & 0.79 & 0.64 & 9.69 & 2.98 \\
\hline $\mathrm{CaO}$ & 0.01 & 6.45 & 2.44 & 2.43 & 2.82 & 2.50 & 2.21 & 13.92 & 7.51 \\
\hline $\mathrm{Na}_{2} \mathrm{O}$ & 0.01 & 3.40 & 3.56 & 3.60 & 3.73 & 3.61 & 3.55 & 0.96 & 1.98 \\
\hline $\mathrm{K}_{2} \mathrm{O}$ & 0.01 & 1.07 & 3.86 & 3.44 & 3.59 & 3.68 & 4.00 & 0.15 & 5.87 \\
\hline $\mathrm{P}_{2} \mathrm{O}_{5}$ & 0.01 & 0.17 & 0.11 & 0.09 & 0.07 & 0.08 & 0.07 & 0.05 & 0.16 \\
\hline $\mathrm{C}$ (tot.) & & $<0.02$ & $<0.02$ & 0.03 & 0.04 & $<0.02$ & 0.03 & 0.09 & 0.65 \\
\hline S(tot.) & & $<0.02$ & $<0.02$ & $<0.02$ & $<0.02$ & $<0.02$ & $<0.02$ & $<0.02$ & 0.04 \\
\hline LOI & & 2.60 & 1.60 & 1.50 & 1.10 & 0.80 & 0.90 & 5.50 & 6.10 \\
\hline Total & & 99.69 & 99.68 & 99.71 & 99.75 & 99.72 & 99.77 & 99.68 & 100.36 \\
\hline$\overline{\mathrm{K}_{2} \mathrm{O} / \mathrm{Na}_{2} \mathrm{O}}$ & & 0.32 & 1.08 & 0.96 & 0.96 & 1.02 & 1.13 & 0.16 & 2.97 \\
\hline $\mathrm{A} / \mathrm{NK}$ & & 2.40 & 1.49 & 1.51 & 1.47 & 1.46 & 1.39 & 8.31 & 1.41 \\
\hline $\mathrm{A} / \mathrm{CNK}$ & & 0.88 & 1.03 & 1.03 & 0.97 & 1.00 & 1.00 & 0.54 & 0.58 \\
\hline $\mathrm{mg} \#$ & & 45.0 & 33.6 & 34.6 & 36.7 & 37.7 & 35.9 & 68.6 & 54.1 \\
\hline $\mathrm{CaO} / \mathrm{Na}_{2} \mathrm{O}$ & & 1.90 & 0.69 & 0.68 & 0.76 & 0.69 & 0.62 & 14.50 & 3.79 \\
\hline Cs & 0.1 & 2.2 & 1.5 & 0.9 & 2 & 1.2 & 1.4 & 0.3 & 1.6 \\
\hline $\mathrm{Rb}$ & 0.1 & 20.8 & 89.1 & 85.4 & 84.1 & 88.2 & 93.7 & 2.4 & 184.6 \\
\hline $\mathrm{Sr}$ & 0.5 & 540.7 & 352.5 & 348.4 & 410.8 & 367.7 & 307.0 & 464.3 & 449.3 \\
\hline $\mathrm{Ba}$ & 1 & 619 & 1927 & 1553 & 1695 & 1930 & 1679 & 79 & 907 \\
\hline Th & 0.2 & 1.7 & 6.2 & 5.1 & 5.7 & 5.4 & 6.5 & 0.2 & 3.1 \\
\hline $\mathrm{U}$ & 0.1 & 1.1 & 2.3 & 2.0 & 2.6 & 2.3 & 2.9 & 0.1 & 5.4 \\
\hline $\mathrm{Zr}$ & 0.1 & 82.3 & 198.7 & 193.1 & 163.4 & 179.1 & 147.6 & 19.9 & 145.3 \\
\hline $\mathrm{Hf}$ & 0.1 & 2.2 & 5.4 & 4.4 & 4.4 & 4.6 & 4.0 & 0.6 & 3.9 \\
\hline $\mathrm{Nb}$ & 0.1 & 3.6 & 8.8 & 7.2 & 6.8 & 6.9 & 7.0 & 0.6 & 5.9 \\
\hline $\mathrm{Ta}$ & 0.1 & 0.2 & 0.5 & 0.4 & 0.4 & 0.4 & 0.4 & 0.1 & 0.4 \\
\hline $\mathrm{Pb}$ & 0.1 & 3.2 & 9.7 & 2.8 & 5.2 & 2.7 & 10.5 & 1.0 & 1.1 \\
\hline $\mathrm{Ga}$ & 0.5 & 17.0 & 13.1 & 13.1 & 12.9 & 12.9 & 13.1 & 13.7 & 8.6 \\
\hline Sn & 1 & 1 & 1 & $<1$ & $<1$ & $<1$ & $<1$ & $<1$ & $<1$ \\
\hline $\mathrm{Ni}$ & 0.1 & 5.4 & 6.9 & 6.8 & 4.1 & 4.6 & 7.8 & 42.0 & 32.3 \\
\hline Co & 0.2 & 24.0 & 5.0 & 5.8 & 4.5 & 4.6 & 3.8 & 42.5 & 10.3 \\
\hline V & 8 & 313 & 62 & 66 & 45 & 52 & 35 & 291 & 100 \\
\hline $\mathrm{Sc}$ & 1 & 28 & 8 & 9 & 7 & 7 & 6 & 43 & 17 \\
\hline $\mathrm{Cu}$ & 0.1 & 49.9 & 28.2 & 39.8 & 19.1 & 16.8 & 17.6 & 53.4 & 78.0 \\
\hline $\mathrm{Zn}$ & 1 & 29 & 36 & 31 & 33 & 25 & 33 & 13 & 46 \\
\hline As & 0.5 & 6.1 & 3.6 & 1.9 & 1.0 & 0.6 & 1.8 & 4.4 & 9.7 \\
\hline W & 0.5 & 0.5 & 0.6 & 0.5 & 0.5 & 0.6 & 0.5 & 0.5 & 0.5 \\
\hline $\mathrm{Au}(\mathrm{ppb})$ & 0.5 & 3.0 & 4.8 & 8.1 & 4.0 & 1.6 & 4.4 & 3.5 & 3.3 \\
\hline $\mathrm{K} / \mathrm{Rb}$ & & 427.0 & 359.6 & 334.4 & 354.4 & 346.4 & 354.4 & 518.8 & 264.0 \\
\hline $\mathrm{Rb} / \mathrm{Sr}$ & & 0.04 & 0.25 & 0.25 & 0.21 & 0.24 & 0.31 & 0.01 & 0.41 \\
\hline $\mathrm{Rb} / \mathrm{Ba}$ & & 0.03 & 0.05 & 0.06 & 0.05 & 0.05 & 0.06 & 0.03 & 0.21 \\
\hline $\mathrm{Y}$ & 0.1 & 21.6 & 26.7 & 21.4 & 21.4 & 20.2 & 19.0 & 10.6 & 24.6 \\
\hline $\mathrm{La}$ & 0.1 & 8.9 & 27.1 & 18.2 & 25.8 & 21.0 & 24.0 & 1.9 & 11.8 \\
\hline $\mathrm{Ce}$ & 0.1 & 22.6 & 54.2 & 36.7 & 48.4 & 41.9 & 46.0 & 4.2 & 26.0 \\
\hline $\operatorname{Pr}$ & 0.02 & 3.32 & 6.69 & 4.32 & 5.67 & 4.79 & 5.14 & 0.67 & 3.46 \\
\hline $\mathrm{Nd}$ & 0.3 & 15.7 & 24.4 & 17.6 & 21.5 & 17.3 & 19.3 & 3.5 & 15.2 \\
\hline $\mathrm{Sm}$ & 0.05 & 3.98 & 4.67 & 3.57 & 3.75 & 3.46 & 3.35 & 1.17 & 3.59 \\
\hline $\mathrm{Eu}$ & 0.02 & 1.09 & 0.93 & 0.71 & 0.81 & 0.75 & 0.68 & 0.45 & 0.81 \\
\hline Gd & 0.05 & 4.21 & 4.21 & 3.36 & 3.23 & 3.20 & 3.07 & 1.58 & 3.71 \\
\hline $\mathrm{Tb}$ & 0.01 & 0.68 & 0.71 & 0.56 & 0.53 & 0.52 & 0.50 & 0.28 & 0.66 \\
\hline Dy & 0.05 & 4.09 & 4.13 & 3.41 & 3.30 & 3.27 & 2.98 & 1.82 & 3.95 \\
\hline Ho & 0.02 & 0.79 & 0.87 & 0.69 & 0.67 & 0.64 & 0.61 & 0.38 & 0.78 \\
\hline $\mathrm{Er}$ & 0.03 & 2.29 & 2.76 & 2.28 & 2.14 & 2.09 & 1.90 & 1.15 & 2.51 \\
\hline $\mathrm{Tm}$ & 0.01 & 0.34 & 0.43 & 0.34 & 0.32 & 0.32 & 0.32 & 0.16 & 0.36 \\
\hline $\mathrm{Yb}$ & 0.05 & 2.29 & 3.02 & 2.39 & 2.44 & 2.27 & 2.33 & 1.04 & 2.48 \\
\hline $\mathrm{Lu}$ & 0.01 & 0.33 & 0.47 & 0.37 & 0.38 & 0.34 & 0.35 & 0.15 & 0.38 \\
\hline$\overline{\mathrm{Eu} / \mathrm{Eu}^{*}}$ & & 0.81 & 0.64 & 0.63 & 0.71 & 0.69 & 0.65 & 1.01 & 0.68 \\
\hline $\mathrm{La}_{\mathrm{N}} / \mathrm{Yb}_{\mathrm{N}}$ & & 2.62 & 6.05 & 5.13 & 7.13 & 6.24 & 6.94 & 1.23 & 3.21 \\
\hline $\mathrm{La}_{\mathrm{N}} / \mathrm{Sm}_{\mathrm{N}}$ & & 1.41 & 3.65 & 3.21 & 4.33 & 3.82 & 4.51 & 1.02 & 2.07 \\
\hline$\Sigma$ REE & & 70.6 & 134.6 & 94.5 & 118.9 & 101.9 & 110.5 & 18.5 & 75.7 \\
\hline
\end{tabular}

Major- and minor elements in wt. \%, trace elements in ppm (except for $\mathrm{Au}$, which is in ppb) 
tion for the assumed granite age of $6 \mathrm{Ma}\left({ }^{207} \mathrm{~Pb} /{ }^{206} \mathrm{~Pb}=\right.$ $0.8361 \pm 0.0836$, i.e., with $10 \%$ uncertainty; Stacey and Kramers 1975). It can be demonstrated that variation of the age of common $\mathrm{Pb}$ based on the Stacey-Kramers model by several Ma does not have a significant effect on the resulting zircon age calculated for the studied samples. Regression of data points for samples Ju311 and Ju346 yielded statistically identical $\mathrm{U}-\mathrm{Pb}$ ages of 6.3 \pm 0.5 and $6.0 \pm 0.4 \mathrm{Ma}$, respectively. However, analyses of zircons from sample Ju328 show variable presence of inherited component, possibly combined with variable content of common $\mathrm{Pb}$ that does not allow a reliable age calculation.

\section{Whole-rock geochemistry}

\subsection{Major and trace elements}

We have analyzed five samples from the felsic suite of the Guacimal Pluton (Tab. 4) and included three additional samples published previously by Cigolini and Chaves (1986). The mafic suite is represented by a single analysis (Ju348, Tab. 4) but additional major-element data were given by Alcorn (1981) with Cigolini and Chaves (1986) for four and three samples, respectively. Unfortunately, there is a dearth of high-precision trace-element analyses. Only Cigolini and Chaves (1986) have presented a handful of trace elements determined by XRF $(\mathrm{Cr}, \mathrm{Co}, \mathrm{Ni}, \mathrm{Cu}$, $\mathrm{Zn}, \mathrm{Rb}, \mathrm{Sr}, \mathrm{Y}, \mathrm{Zr}, \mathrm{Nb}$ and $\mathrm{Ba}$ ).

\subsubsection{Felsic suite}

Despite some textural and modal variation, the felsic suite shows a remarkable geochemical homogeneity. Using CIPW normative proportions for plotting the QAP diagram (Streckeisen 1974) (Fig. 12a), these samples can be classified as transitional between monzogranites and granodiorites $\left(\mathrm{SiO}_{2}=68.8-71.6 \mathrm{wt}\right.$ \% ; analyses by Cigolini and Chaves 1986 reaching up to 75.4 wt. \%). Such a conclusion is in line with the $\mathrm{P}-\mathrm{Q}$ multicationic plot (Debon and Le Fort 1983; 1988; Fig. 12b), which, however, employs the obsolete term 'adamellite', now discredited by the IUGS. The ternary diagram $\mathrm{Na}_{2} \mathrm{O}-$ $\mathrm{Al}_{2} \mathrm{O}_{3}-\mathrm{K}_{2} \mathrm{O}$ (mol. \%, Fig. 12c) demonstrates that the contents of both alkalis are roughly balanced $\left(\mathrm{K}_{2} \mathrm{O} / \mathrm{Na}_{2} \mathrm{O}\right.$ $=0.96-1.21$ in wt. \%).

The rocks are subaluminous as shown by the values of Shand's alumina saturation index, A/CNK (molar $\mathrm{Al}_{2} \mathrm{O}_{3} /\left(\mathrm{CaO}+\mathrm{Na}_{2} \mathrm{O}+\mathrm{K}_{2} \mathrm{O}\right)$ uncorrected for apatite $)$ of 0.97-1.03 (Tab. 4; but analyses by Cigolini and Chaves 1986 yield $\mathrm{A} / \mathrm{CNK}$ values up to 1.13 ) as demonstrated also by the multicationic diagram B-A (Debon and Le Fort 1983; 1988) (Fig. 12d). Additionally, this plot can serve to express the contents of mafic components $\mathrm{Fe}, \mathrm{Mg}$ and $\mathrm{Ti}(=\mathrm{B})$ and thus the characteristic mineral assemblage. Typical of the felsic suite are low $\mathrm{B}$ values, mostly fulfilling the definition of leucogranitoids $(B<50)$, and this, together with the A values oscillating around zero, points to essentially biotite-bearing assemblages, with, or without, some amphibole. The AFM and $\mathrm{SiO}_{2}$ vs. $\mathrm{K}_{2} \mathrm{O}$ diagrams (Figs. 12e-f) document that the felsic suite is clearly high-K calc-alkaline in character (3.4-4.0 wt. \% $\mathrm{K}_{2} \mathrm{O}$ ).

The NMORB-normalized spiderplots (Sun and McDonough 1989) for the felsic suite are characterized by a strong enrichment in incompatible elements $\left(\mathrm{Rb}_{\mathrm{N}}=\right.$ $150-167 \times \mathrm{NMORB})$ over the more compatible ones $\left(\mathrm{Lu}_{\mathrm{N}}\right.$ $=0.75-1.03 \times$ NMORB) $($ Fig. 13a). Superimposed are positive anomalies in $\mathrm{Ba}, \mathrm{U}, \mathrm{K}$ and $\mathrm{Pb}$, as well as troughs in $\mathrm{Nb}, \mathrm{P}$ and $\mathrm{Ti}$, which are generally considered as typical of fractionated subduction-related magmas (Pearce and Peate 1995; Tatsumi and Eggins 1995). The total REE concentrations are rather high, 94.5-134.6 ppm, and the chondrite-normalized REE patterns (Boynton 1984) for felsic samples are all subparallel, featuring a strong LREE/HREE enrichment $\left(\mathrm{La}_{\mathrm{N}} / \mathrm{Yb}_{\mathrm{N}}=5.1-7.1 ; \mathrm{La}_{\mathrm{N}} / \mathrm{Sm}_{\mathrm{N}}\right.$ $=3.2-4.5$; Fig. 13b, Tab. 4), MREE depletion $\left(\mathrm{Dy}_{\mathrm{N}} / \mathrm{Yb}_{\mathrm{N}}\right.$ $<1$, Fig. 14a) and deep negative Eu anomalies (Eu/Eu* $=0.63-0.71$ where $\left.\mathrm{Eu}^{*}=\sqrt{S m_{N} G d_{N}}\right)$. The concentrations

Fig. 12 Major-element based diagrams for magmatic rocks of the Guacimal Pluton (for data sources, see the text). a - The QAP diagram (Streckeisen 1974). Instead of modal proportions, CIPW normative compositions are plotted as follows: $\mathrm{Q}=$ Quartz $(Q z), \mathrm{A}=$ Alkali feldspar $(\mathrm{Or})$, $\mathrm{P}=$ Plagioclase $(A b+A n) ; \mathbf{b}-$ Multicationic plot $\mathrm{P}-\mathrm{Q}$ (Debon and Le Fort 1983, 1988) (P representing the proportion of K-feldspar to plagioclase and $\mathrm{Q}$ the quartz content): $\mathrm{gr}=$ granite, $\mathrm{ad}=$ adamellite, $\mathrm{gd}$ $=$ granodiorite, to $=$ tonalite, $\mathrm{sq}=$ quartz syenite, $\mathrm{mzq}=$ quartz monzonite, $\mathrm{mzdq}=$ quartz monzodiorite, $\mathrm{dq}=$ quartz diorite, $\mathrm{s}=$ syenite, $\mathrm{mz}=$ monzonite, $\mathrm{mzgo}=$ monzogabbro, $\mathrm{go}=$ gabbro $; \mathbf{c}-$ Ternary plot $\mathrm{Na}_{2} \mathrm{O}-\mathrm{Al}_{2} \mathrm{O}_{3}-\mathrm{K}_{2} \mathrm{O}$ (mol. \%). Dashed lines define the following compositional fields: peraluminous + metaluminous, $\left(\mathrm{Na}_{2} \mathrm{O}+\mathrm{K}_{2} \mathrm{O}\right) / \mathrm{Al}_{2} \mathrm{O}_{3}$ $<1$; peralkaline, $\left(\mathrm{Na}_{2} \mathrm{O}+\mathrm{K}_{2} \mathrm{O}\right) / \mathrm{Al}_{2} \mathrm{O}_{3}>1$; perpotassic, $\mathrm{K}_{2} \mathrm{O} / \mathrm{Al}_{2} \mathrm{O}_{3}>$ 1 and $\mathrm{K}_{2} \mathrm{O} / \mathrm{Na}_{2} \mathrm{O}>1$; potassic, $1<\mathrm{K}_{2} \mathrm{O} / \mathrm{Na}_{2} \mathrm{O}<3$; and ultrapotassic, $\mathrm{K}_{2} \mathrm{O} / \mathrm{Na}_{2} \mathrm{O} \geq 3$ in mol. \% (or $\mathrm{K}_{2} \mathrm{O} / \mathrm{Na}_{2} \mathrm{O} \geq 2$ in wt. \%, which is equivalent to the definition of ultrapotassic igneous rocks by Foley et al. 1987); d - Multicationic plot B-A (B being proportional to the amount of mafic minerals and $\mathrm{A}$ expressing the alumina saturation) (Debon and Le Fort 1983,1988); e - AFM diagram ( $\mathrm{A}=\mathrm{Na}_{2} \mathrm{O}+\mathrm{K}_{2} \mathrm{O}, \mathrm{F}=\mathrm{FeOt}, \mathrm{M}$ $=\mathrm{MgO}$ : Irvine and Baragar 1971) illustrating the calc-alkaline trend defined by the Guacimal Pluton analyses; $\mathbf{f}-\mathrm{SiO}_{2}-\mathrm{K}_{2} \mathrm{O}$ plot (wt. \%) with discrimination boundaries between the (low-K) tholeiitic, (medium-K) calc-alkaline, high-K calc-alkaline, and shoshonitic rocks after Peccerillo and Taylor (1976). The colour fields denote the variation in other Neogene plutonic bodies of Costa Rica (in brackets are references and number of analyses in the database): Talamanca Intrusive Suite (Tournon 1984 - 1, Drummond et al. 1995 - 8, Gräfe 1998 - 41, Abratis 1998 - 13, Ulloa and Delgado 2010 - 15); Puerto Nuevo Gabbros (Henningsen 1966 - 2, Abratis 1998 - 2); Escazú monzonites-gabbros (Bergoeing 1982 - 2), Guayacan teschenite (Azambre and Tournon 1977 - 4), Desmonte monzogabbro (Tournon 1984 - 1) and Dominical gabbros (Gazel et al. $2009-2$ ). 

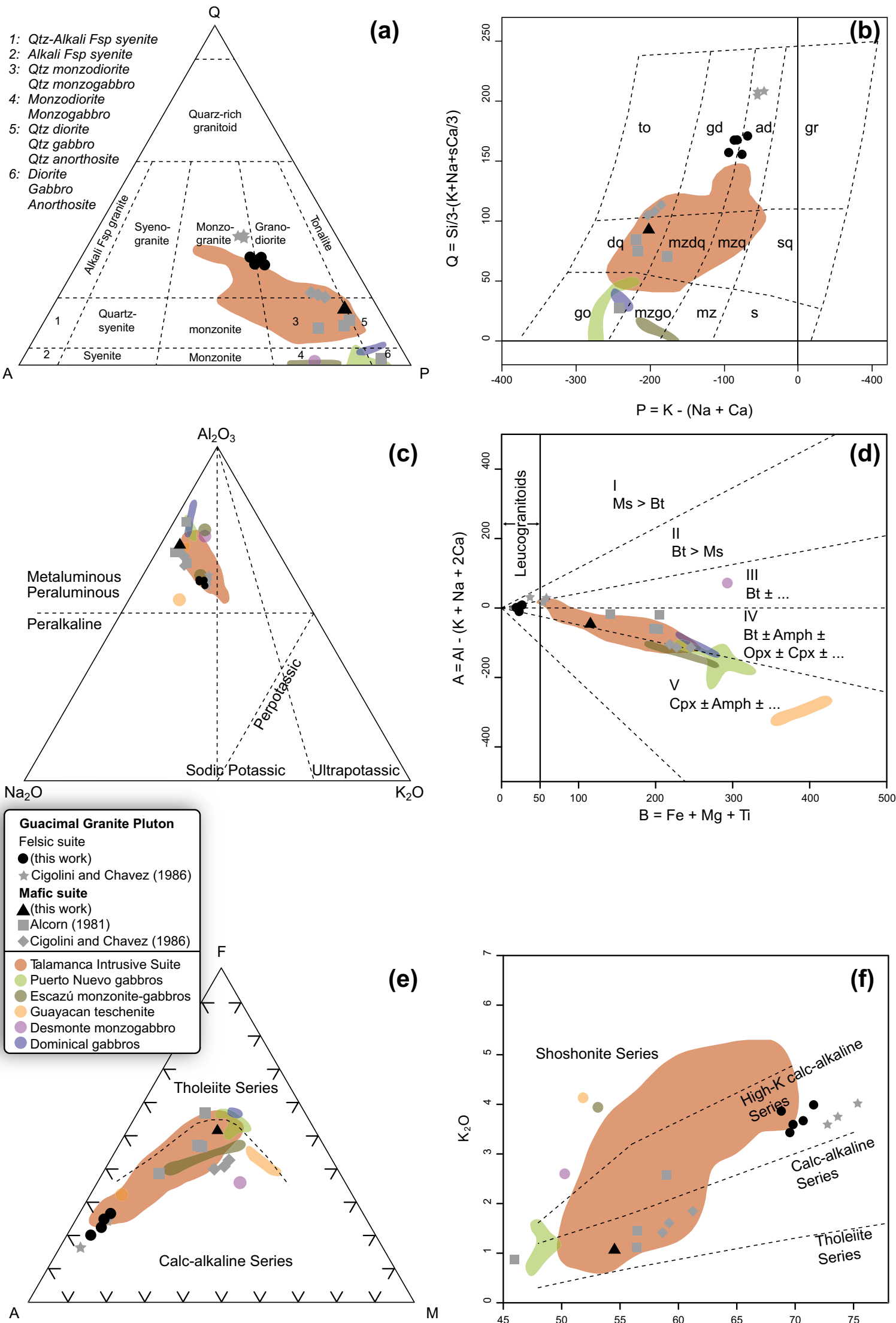

Felsic suite

(this work)

Cigolini and Chavez (1986)

Puerto Nuevo gabbro

monzonite-gabbros

Desmonte monzogabbro

Dominical gabbros

(e)

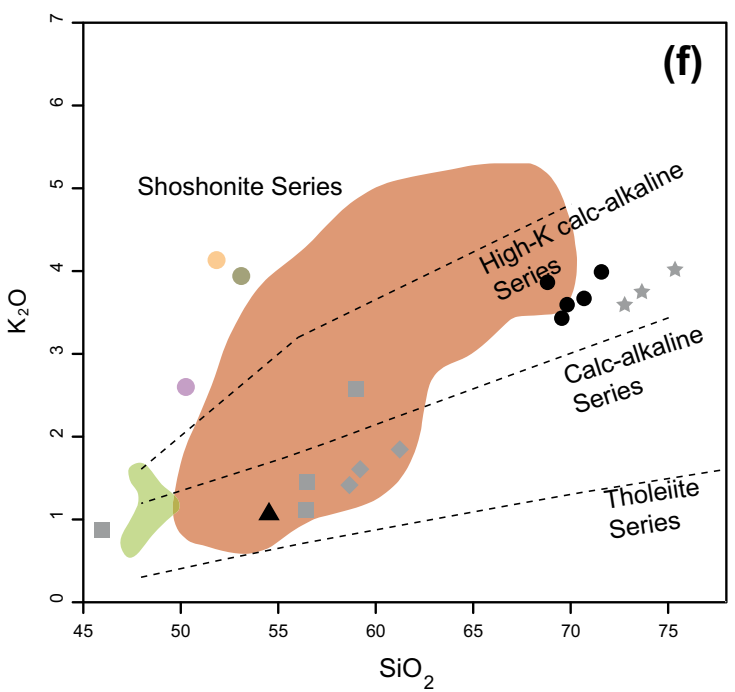


of HREE and Y markedly decrease with increasing silica (e.g., Fig. 14b).

The negative $\mathrm{SiO}_{2}-\mathrm{Zr}$ correlation (Fig. 14c) for felsic samples is taken as evidence that zircon saturation was reached early in the fractionation process (Hoskin et al. 2000; Janoušek 2006). Therefore, the zircon saturation calculations (Watson and Harrison 1983) were employed to provide an upper constraint on the liquidus temperature of the granitic melt (due to possible inheritance). The obtained median value for the new analyses is 790.7
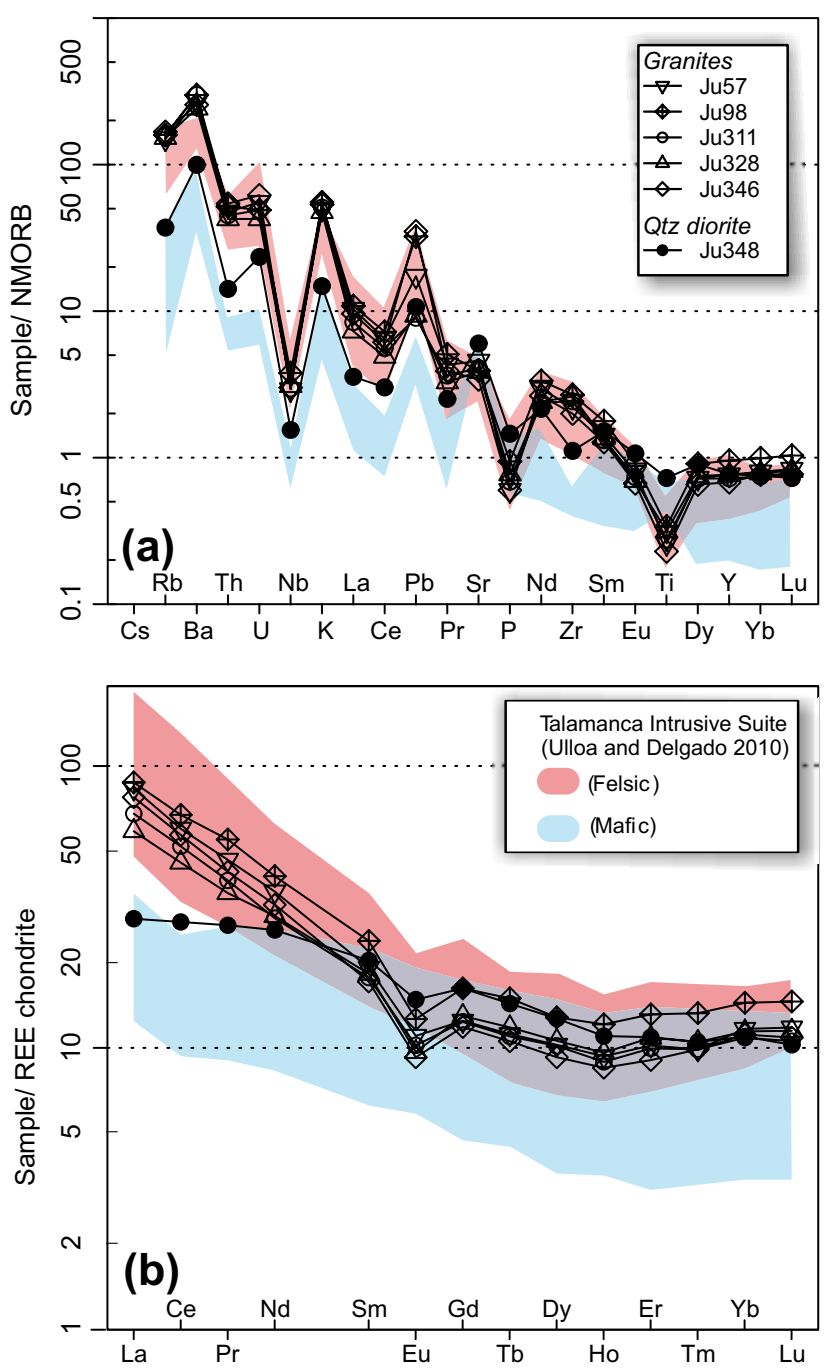

Fig. 13 Multielement variation plots ('spiderplots') for the Guacimal Pluton. a - Trace-element values normalized by NMORB (Sun and McDonough 1989). b - Chondrite (Boynton 1984) normalized REE patterns. Colour fields denote the variation in the Talamanca Intrusive Suite (Ulloa and Delgado 2010); pink for its felsic suite (11 monzogranites and granodiorites) and blue for the mafic suite ( 3 quartz gabbros/quartz diorites). The mafic suite of Talamanca has less than $52.2 \% \mathrm{SiO}_{2}$ and its REE patterns do not show a negative Eu anomaly. $\pm 24.8^{\circ} \mathrm{C}(2 \sigma)$; the temperatures calculated for data by Cigolini and Chaves (1986) range from 798 to $810^{\circ} \mathrm{C}$.

\subsubsection{Mafic suite}

The mafic rocks are rather variable in composition $\left(\mathrm{SiO}_{2}\right.$ = 45.9-61.2 wt. \%), but are all exclusively metaluminous $(\mathrm{A} / \mathrm{CNK}=0.71-0.95)$ and sodium-rich $\left(\mathrm{K}_{2} \mathrm{O} / \mathrm{Na}_{2} \mathrm{O}=\right.$ $0.27-0.59$ wt. \%, Tab. 4, see also Fig. 12c-d). In the QAP and P-Q diagrams (Streckeisen 1974; Debon and Le Fort 1983, 1988), sample Ju348 corresponds to quartz diorite (Fig. 12a-b). The literature data straddle the boundaries of the adjacent quartz monzodiorite/quartz monzogabbro and tonalite domains (P-Q plot) . However, not all mafic samples represent liquid compositions; at least some seem to contain a significant proportion of cumulus material rich in calcic plagioclase and biotite. For instance, the gabbro G12 is very basic and aluminous $\left(\mathrm{SiO}_{2}=45.92\right.$ wt. $\%, \mathrm{Al}_{2} \mathrm{O}_{3}=21.3$ wt. $\%$ ) and, indeed, this sample shows as much as 53.9 vol. \% of plagioclase (Alcorn 1981). The degree of fractionation, expressed by $\mathrm{mg} \#$ [molar $100 \times$ $\mathrm{MgO} /(\mathrm{MgO}+\mathrm{FeOt})]$, is also highly variable (35.5-66.0). The rocks are mostly normal- $\mathrm{K}$ calc-alkaline $\left(\mathrm{K}_{2} \mathrm{O}=\right.$ $0.9-1.8$ wt. \%), with exception of the sample G-5, which is more potassium-rich $\left(\mathrm{K}_{2} \mathrm{O}=2.6\right.$ wt. \%) (Fig. 12e-f).

The NMORB-normalized pattern of the sample Ju348 (Fig. 13a) shows features similar to the felsic suite. Still, it contains much lower concentrations of LILE ( $\mathrm{Rb}, \mathrm{Ba}, \mathrm{U}$, Th and $\mathrm{K}$ ), and the troughs in Ti and $\mathrm{P}$ are shallower. On the other hand, the $\mathrm{Nb}$ anomaly is prominent, the LREE contents are significantly lower $\left(\mathrm{La}_{\mathrm{N}}=28.7 \times \mathrm{NMORB}\right)$ but the HREE abundances are similar to some members of the felsic suite $\left(\mathrm{Lu}_{\mathrm{N}}=0.73 \times \mathrm{NMORB}\right)$. As a consequence, the sample is rather REE poor $(\Sigma \mathrm{REE}=70.6 \mathrm{ppm})$ and its chondrite-normalized REE pattern (Fig. 13b) is much flatter, in particular in its LREE segment $\left(\mathrm{La}_{\mathrm{N}} / \mathrm{Yb}_{\mathrm{N}}=2.6 ; \mathrm{La}_{\mathrm{N}} /\right.$ $\left.\mathrm{Sm}_{\mathrm{N}}=1.4\right)$. The negative Eu anomaly is still significant, but somewhat less conspicuous $\left(\mathrm{Eu} / \mathrm{Eu}^{*}=0.81\right)$.

\section{2. $\mathrm{Sr}-\mathrm{Nd}$ isotopes}

Whole-rock isotopic ratios for three granites-granodiorites of the Guacimal Pluton are presented in Tab. 5 and plotted in Fig. 15. The $\mathrm{Sr}$ and $\mathrm{Nd}$ isotopic data are all remarkably uniform $\left({ }^{87} \mathrm{Sr}^{86}{ }^{86} \mathrm{Sr}_{6} \sim 0.70388, \varepsilon_{\mathrm{Nd}}^{6} \sim+7.4\right.$ to +7.6$)$ and primitive, thus documenting a short crustal residence of their source (two-stage $\mathrm{Nd}$ model ages after Liew and Hofmann (1988), $\mathrm{T}_{\mathrm{Nd}}^{\mathrm{DM}}$, ranging between 0.196 and 0.213 $\mathrm{Ga}$ ). The $\mathrm{Rb}-\mathrm{Sr}$ isotopic compositions would even form a crude linear array (errorchron) with slope corresponding to an age $\sim 7 \mathrm{Ma}$. 

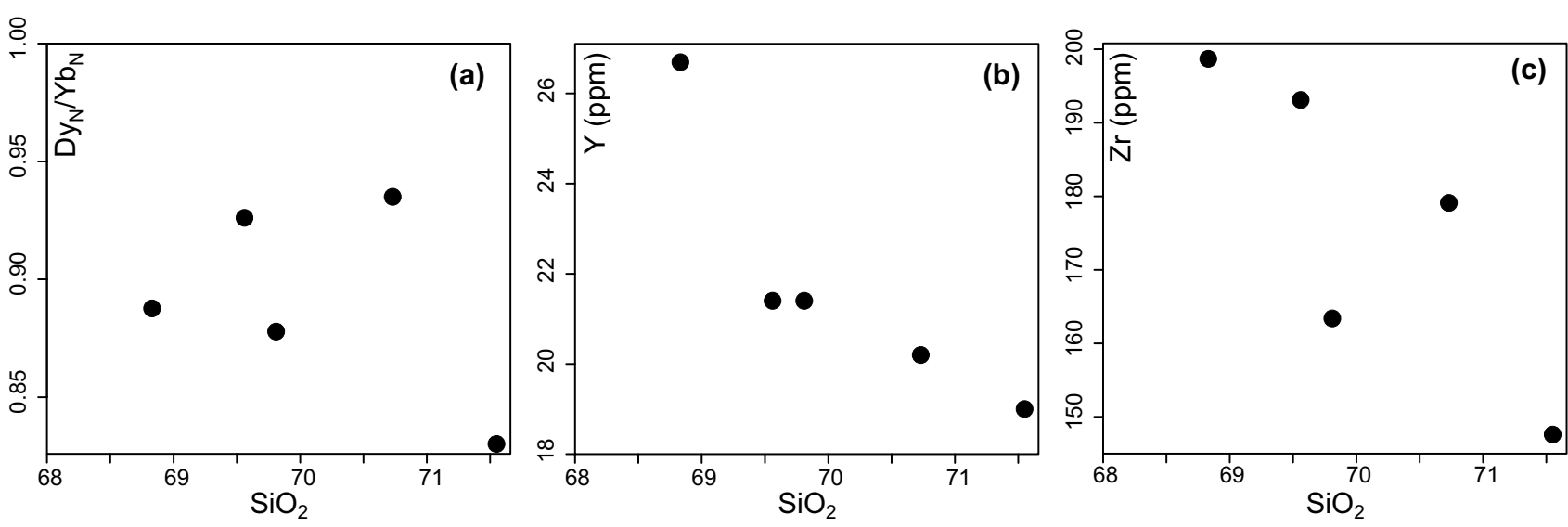

Fig. 14 Binary plots of $\mathrm{SiO}_{2}$ vs. $\mathrm{Dy}_{\mathrm{N}} / \mathrm{Yb}_{\mathrm{N}}$ (normalized to chondritic values of Boynton 1984) $\mathrm{Y}$ and $\mathrm{Zr}$ for the felsic suite of the Guacimal Pluton.

Tab $5 \mathrm{Sr}-\mathrm{Nd}$ isotopic data

\begin{tabular}{|c|c|c|c|c|c|c|c|c|c|c|c|c|c|c|}
\hline Sample & $\begin{array}{c}\mathrm{Rb} \\
(\mathrm{ppm})\end{array}$ & $\begin{array}{c}\mathrm{Sr} \\
(\mathrm{ppm})\end{array}$ & ${ }^{87} \mathrm{Rb} /{ }^{86} \mathrm{Sr}$ & ${ }^{87} \mathrm{Sr} /{ }^{86} \mathrm{Sr}$ & $2 \mathrm{se}(\mathrm{m})$ & ${ }^{87} \mathrm{Sr} /{ }^{86} \mathrm{Sr}_{6}{ }^{*}$ & $\begin{array}{c}\mathrm{Sm} \\
(\mathrm{ppm})\end{array}$ & $\begin{array}{c}\mathrm{Nd} \\
(\mathrm{ppm})\end{array}$ & ${ }^{7} \mathrm{Sm} /{ }^{144} \mathrm{Nd}$ & ${ }^{43} \mathrm{Nd} /{ }^{144} \mathrm{Nd}$ & $2 \mathrm{se}(\mathrm{m})$ & ${ }^{143} \mathrm{Nd} /{ }^{144} \mathrm{Nd}_{6}{ }^{*}$ & $\varepsilon_{\mathrm{Nd}}^{6 *}$ & $\mathrm{~T}_{\mathrm{Nd}}^{\mathrm{DM}}$ \\
\hline J311 & 88.2 & 367.7 & 0.69400 & 0.703937 & 0.000012 & 0.703878 & 3.46 & 17.3 & 0.12093 & 0.513025 & & & 7.6 & 0,105 \\
\hline UU328 & 85.4 & 348.4 & 0.70920 & 0.703942 & 0.000014 & 0.703882 & 3.57 & 17.6 & 0.12264 & 0.513013 & 0.000008 & 0.513008 & 7.4 & 0.213 \\
\hline UU346 & 93.7 & 307.0 & 0.88306 & 0.703958 & 0.000011 & 0.703883 & 3.35 & 19.3 & 0.10495 & 0.513021 & 0.000010 & 0.513017 & 7.5 & 0.200 \\
\hline
\end{tabular}

* Subscripts indicate age to which were isotopic ratios corrected;

epsilon values calculated using Bulk Earth parameters given by Jacobsen and Wasserburg (1980);

$\mathrm{T}_{\mathrm{Nd}}^{\mathrm{DM}}$ are two-stage Nd model ages based on Liew and Hofmann (1988)

\section{Discussion}

\subsection{Crystallization conditions and age}

The granitic rocks of the Guacimal pluton contain primary magmatic assemblage of quartz, plagioclase, K-feldspar, Mg-rich biotite, amphibole, magnetite, and titanite. The presence of quartz, magnetite and titanite indicates relatively high oxygen fugacity (Wones 1989). This is supported by estimates of oxygen fugacity (Ridolfi et al. 2010), which fall in the interval of 1.6-2.1 log units above the NNO buffer. Together with the geochemical evidence for plagioclase and biotite accumulation in more mafic samples, these calculations indicate that the felsic members of the pluton were emplaced at shallow depth of $\sim 3 \mathrm{~km}$ at a relatively high $f \mathrm{O}_{2}$, whereas the mafic rocks could represent deeper $(\sim 15 \mathrm{~km})$ cumulates.

The intrusive rocks contain ubiquitous secondary minerals, which are mostly present in interstitial space in the rock matrix or as fillings of miarolitic cavities. They include quartz II, K-feldspar II (adularia), epidote, chlorite (clinochlore), amphibole II (actinolite), ilmenite II and titanite II. The secondary titanite is extremely rich in $\mathrm{Al}_{2} \mathrm{O}_{3}(5.19-11.26$ wt. \%) and $\mathrm{F}(1.46-3.93$ wt. \%). The heterovalent substitution of titanium by aluminium was first recognized by Sahama (1946): $\mathrm{Al}^{3+}+(\mathrm{OH}, \mathrm{F})$ $=\mathrm{Ti}^{4+}+\mathrm{O}^{2-}$. Following Franz and Spear (1984) such a mechanism is favoured either by high pressure or low temperature, in addition to high fluorine activity.

New LA ICP-MS dating of zircons from two granite samples of the Guacimal Pluton yielded statistically identical $\mathrm{U}-\mathrm{Pb}$ ages of $6.3 \pm 0.5$ and $6.0 \pm 0.4 \mathrm{Ma}$. This broadly agrees with the $\mathrm{K}-\mathrm{Ar}$ age on a monzonite (biotite: $3.9 \pm 1.0 \mathrm{Ma}$, alkali feldspar: $5.0 \pm 0.2 \mathrm{Ma}$; Schulz et al. 1987) and a quartz diorite (whole rock: 7.2 $\pm 1.4 \mathrm{Ma}$; Alvarado et al. 1992). The Guacimal Pluton thus ranks to the youngest Neogene plutonic rocks in Costa Rica, being comparable in age to the Escazú Pluton (6.3-2.2 $\mathrm{Ma})$, the youngest plutonic member of the Talamanca Igneous Suite (7.8-3.89 Ma), the Guacayán Intrusion (4.5 $\mathrm{Ma}$ ) and the Desmonte monzogabbro (2.1 Ma) (all K-Ar data - Bellon and Tournon 1978; Patino 2007).

\subsection{Whole-rock geochemistry}

The major-element whole-rock composition of the Guacimal Pluton closely resembles the other Costa Rican Neogene plutonic rocks, especially the Talamanca Intrusive Suite (Fig 12). This argues for comparable sources and processes involved in generation of granitic magmas along the whole (now extinct) arc. However, some intrusive rocks from the back arc (Guayacán teschenite) are alkaline and clearly had different genesis associated to their likely OIB source (Gazel 2003). 


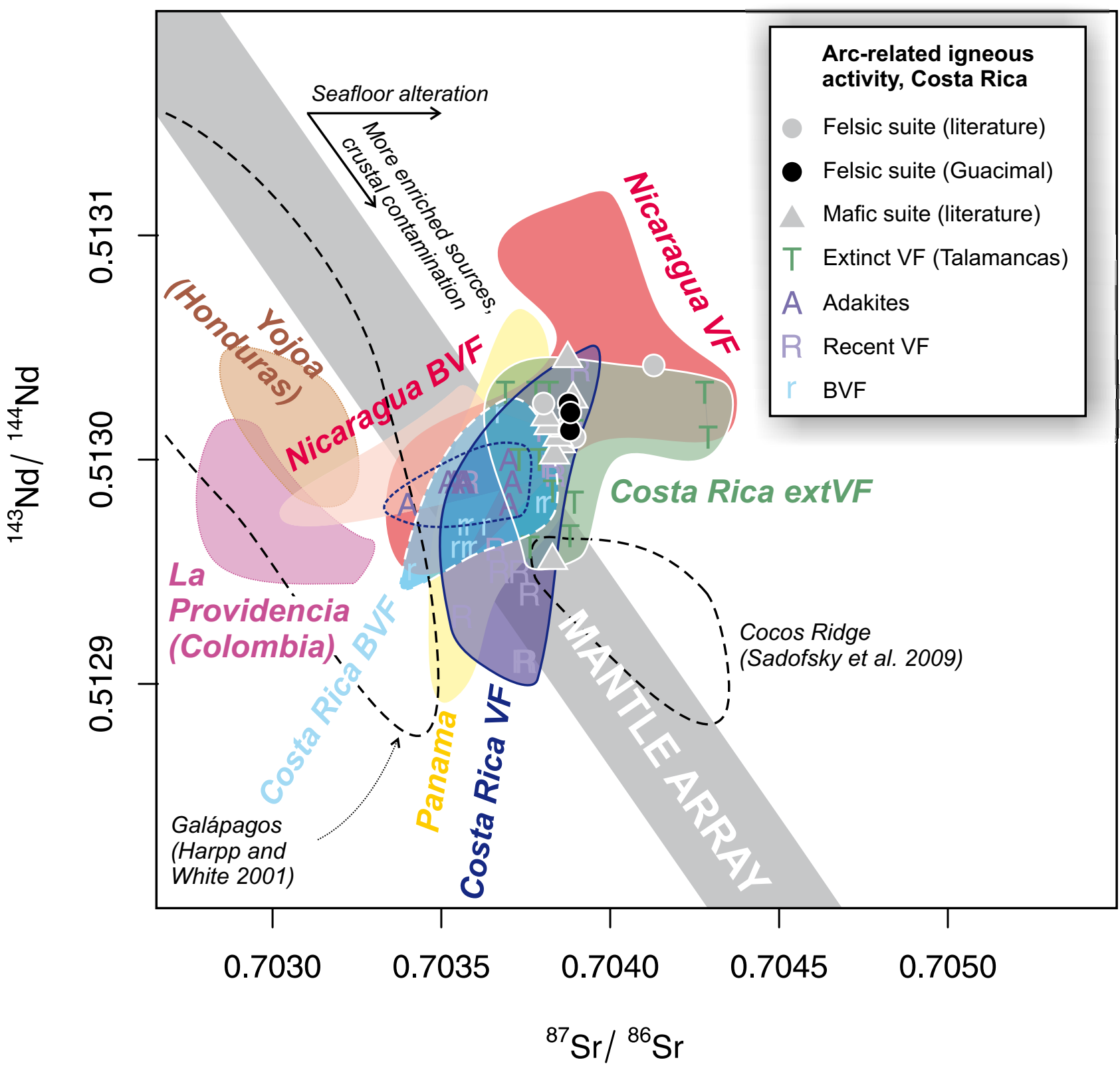

Fig. 15 Present-day Sr-Nd isotopic diagram for the pre-Quaternary felsic and mafic intrusive rocks of Costa Rica (seven diorites of Gräfe 1998, tholeiitic gabbro INA-84 and calc-alkaline monzodiorite ALT 95 from Abratis 1998, and this work). The context is provided by analyses of arc-related igneous rocks from Costa Rica: extinct volcanic front (VF) and adakites in Cordillera de Talamanca, recent VF in western Costa Rica and related behind-volcanic front (BVF) volcanism (Abratis 1998; Feigenson et al. 2004). For comparison, shown are also the fields of the Central American Volcanic Arc (CAVA) data from the neighbouring countries - recent/extinct VF and BVF lavas in Nicaragua, VF lavas in Panama and BVF lavas from Colombian Isla de Providencia (Feigenson et al. 2004; Janoušek et al. 2010). Also plotted are fields of Yojoa BVF lavas derived from an OIB-like source in back-arc setting in Honduras (Feigenson et al. 2004), Galápagos lavas (Harpp and White 2001) and Cocos Ridge analyses (Sadofsky et al. 2009). Gray field indicates approximate extent of the Mantle Array.

The trace-element compositions of the Guacimal intrusive suite are well within the range of the Talamanca Intrusive Suite (Fig 13), the former only show more pronounced $\mathrm{Eu}$ anomalies. Vogel et al. (2004) pointed out that the trace-element distribution in the Costa Rican silicic ignimbrites resembles that in the plutonic rocks (granites and granodiorites of the Talamanca Intrusive
Suite; Drummond et al. 1995; Abratis 1998). Moreover, it is close to the composition of the average upper continental crust, a conclusion valid for the Guacimal samples as well.

The rocks of the felsic Guacimal suite show only moderate negative $\mathrm{Eu}$ anomalies accompanied by a marked depletion in MREE (e.g., low $\mathrm{Dy}_{\mathrm{N}} / \mathrm{Yb}_{\mathrm{N}}=0.83-0.94$ ), cor- 
responding to the low-temperature, hydrous and oxidized suite of high- $\mathrm{SiO}_{2}$ rhyolites as defined by Bachmann and Bergantz (2008). This is in agreement with rather low estimated temperatures of magmatic crystallization (c. $760-800^{\circ} \mathrm{C}$ ). The observed MREE depletion is in line with an important role of amphibole and/or titanite either in the residue after melting, or, more likely, in the fractionating assemblage (Gromet and Silver 1983; Tiepolo et al. 2002, 2007; Davidson et al. 2007).

\subsection{Sr-Nd isotopes}

As shown in Fig. 15, the $\mathrm{Sr}-\mathrm{Nd}$ isotopic signatures for the Guacimal granites-granodiorites form a rather tight cluster slightly off to the right of the Mantle Array. When compared with the subduction-related Costa Rican volcanic rocks, they fall into the most primitive (low ${ }^{87} \mathrm{Sr} /{ }^{86} \mathrm{Sr}$, high ${ }^{143} \mathrm{Nd} /{ }^{144} \mathrm{Nd}$ ) corner of the field occupied by the analyses from the extinct Cordillera de Talamanca volcanic front; they also coincide with the top (most radiogenic $\mathrm{Nd}$ ) part of the nearly vertical isotopic data array for the recent volcanic arc, including most of the silicic ignimbrites (see "trend 1" in fig. 23.8 of Vogel et al. 2007). On the other hand, they definitely have less radiogenic $\mathrm{Nd}$ and more radiogenic $\mathrm{Sr}$ than the current behind-volcanic front (BVF) volcanics of the same arc. The Sr-Nd isotopic compositions of the Guacimal Pluton, however, compare particularly well with the previously determined data ${ }^{87} \mathrm{Sr}^{86} \mathrm{Sr}_{6}=0.70380-0.70413, \varepsilon_{\mathrm{Nd}}^{6} \sim+7.3$ to +7.9) from Neogene intermediate-acid calc-alkaline plutonic rocks from Costa Rica (tonalite to alkali granite samples CHI 116, INA 85, TAL 79 and 19 of Abratis 1998 and Gräfe 1998).

\subsection{Magma source and evolution}

In the Guacimal Pluton, the homogeneous $\mathrm{Sr}-\mathrm{Nd}$ isotopic compositions exclude open-system processes such as contamination by evolved continental crust or magma mixing between primitive, mantle-derived melts and magmas generated by anatexis of isotopically contrasting continental crust (see also Vogel et al. 2004). The available data for the extinct arc in Cordillera de Talamanca (seven diorites of Gräfe 1998, tholeiitic gabbro INA-84 and calcalkaline monzodiorite ALT 95 from Abratis 1998) span identical range as the Guacimal suite does in both $\mathrm{Nd}\left(\varepsilon_{\mathrm{Nd}}^{6}\right.$ $\sim+7.2$ to +8.0$)$ and $\mathrm{Sr}\left({ }^{87} \mathrm{Sr}^{86} \mathrm{Sr}_{6}=0.70381-0.70389\right)$, and this appears to support the origin by differentiation in a closed system.

The observed slight shift to the more radiogenic $\mathrm{Sr}$ (right from the Mantle Array) in intrusive rocks, including the Guacimal Pluton, probably reflects a role of hydrous, subduction-related fluids that tend to be rather Sr-rich but Nd-poor (Feigenson and Carr 1986). As dis- cussed by Janoušek et al. (2010), subducted metabasic rocks of the Cocos Plate should have significantly elevated $\mathrm{Sr}$ isotopic ratios due to the seawater alteration, and this is indeed shown by the analyses of the Galápagos-influenced ocean-floor lavas (Sadofsky et al. 2009) (Fig. 15). Such an effect is even more clearly seen in the recent Nicaraguan volcanic-front lavas, which are, in particular in the NW Nicaragua, thought to have been derived from a strongly depleted mantle wedge (Carr et al. 2007 and references therein; Hoernle et al. 2008; Sadofsky et al. 2009).

As there are only very limited reliable data for the mafic rocks, we shall exclusively focus on the felsic suite. Its rather homogeneous, radiogenic $\mathrm{Nd}$ and fairly unradiogenic $\mathrm{Sr}$ isotopic signatures require: (1) partial melting of young, immature metaigneous crust (including a subrecent basic magma underplate, which is believed to form near the Moho level of long-lived igneous arcs - Atherton and Petford 1993), or (2) direct fractionation from fairly depleted mantle-derived magmas (see also Vogel et al. 2004, 2006).

The presence of marked negative Eu anomalies in the Guacimal granitic rocks would be compatible with an anatexis of a feldspar-rich source, leaving much of this mineral in the residue. The $\mathrm{CaO} / \mathrm{Na}_{2} \mathrm{O}$ ratios in anatectic magmas are controlled mostly by the protolith's plagioclase/clay ratio (Sylvester 1998; Jung and Pfänder 2007). The felsic suite is characterized by high $\mathrm{CaO} / \mathrm{Na}_{2} \mathrm{O}$ ratios (0.62-0.76; Tab. 4), pointing to mainly a plagioclase-rich, and thus not metapelitic, source. Such a conclusion is in line with the subaluminous nature, as well as low $\mathrm{Rb} / \mathrm{Sr}$ and $\mathrm{Rb} / \mathrm{Ba}$ ratios of the Guacimal granites (Harris and Inger 1992; Tab. 4). In addition, in the binary plot $\mathrm{Al}_{2} \mathrm{O}_{3}$ $+\mathrm{FeOt}+\mathrm{MgO}+\mathrm{TiO}_{2}$ vs. $\mathrm{Al}_{2} \mathrm{O}_{3} /\left(\mathrm{FeOt}+\mathrm{MgO}+\mathrm{TiO}_{2}\right)$ of Jung et al. (2009) the felsic Guacimal samples fall clearly into a domain occupied by experimental melts of intermediate metaigneous or metapsammitic parentage (Fig. 16).

Roberts and Clemens (1993) as well Sisson et al. (2005) concluded, based on experimental data, that the high-K calc-alkaline granitic magmas - such as those in Guacimal Pluton - may be derived exclusively by intracrustal partial melting of hydrous, calc-alkaline to high-K calc-alkaline, mafic to intermediate metaigneous rocks. The modal composition of the Guacimal granitic rocks rules out partial melting of common K-poor metabasites as it should lead to tonalitic-trondhjemitic and not granodioritic-granitic melts (e.g., Wolf and Wyllie 1994; Rapp and Watson 1995; Johannes and Holtz 1996). On the same basis can be effectively discounted the model of Atherton and Petford (1993) invoking remelting of the deep crustal metabasic underplate. Moreover, the magmas parental to the Guacimal granitoids were apparently too cold to have formed by dehydration melting of amphibole at reasonable depths (e.g., Miller et al. 


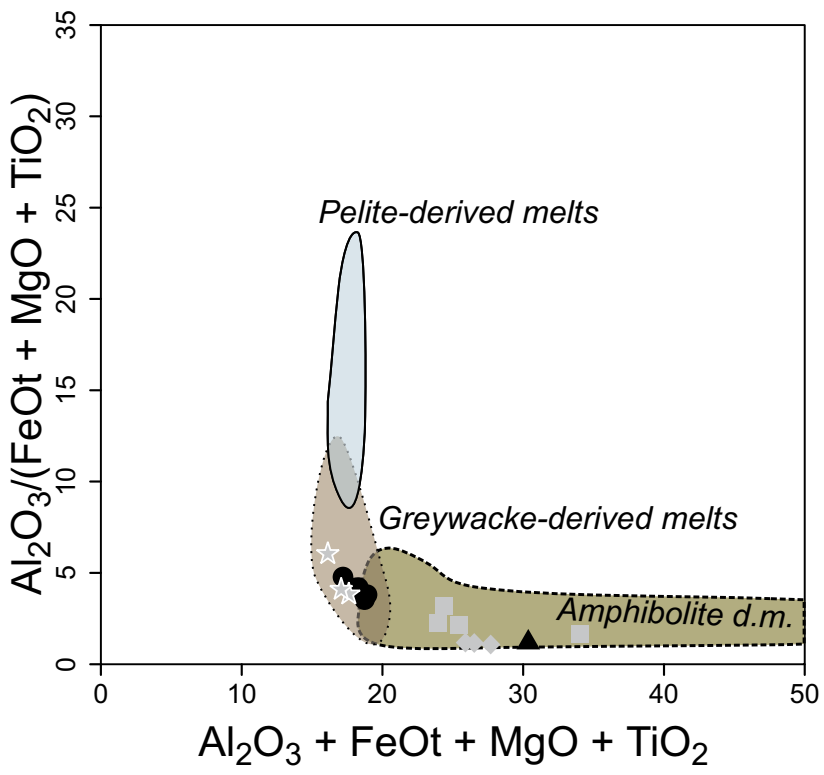

Fig. 16 Binary plot of $\mathrm{Al}_{2} \mathrm{O}_{3}+\mathrm{FeOt}+\mathrm{MgO}+\mathrm{TiO}_{2}$ vs. $\mathrm{Al}_{2} \mathrm{O}_{3} /(\mathrm{FeOt}$ $+\mathrm{MgO}+\mathrm{TiO}_{2}$ ); outlined are domains occupied by experimental granitic melts obtained by partial melting of metapelites, metagreywackes and amphibolites (experiments of Patiño Douce 1999 as summarised by Jung et al. 2009). Within the Guacimal Pluton suite, the mafic group clearly requires a metabasic source, while the felsic rocks could be derived from intermediate metaigneous or metapsammitic sources.

2003). If true, the partial melting model would require a $\mathrm{K}$-rich, rather young, intermediate metaigneous source, that is volcanics, volcaniclastics or immature graywackes, rich in the arc-derived volcanogenic detritus. All such lithologies would be characterized by primitive $\mathrm{Sr}-\mathrm{Nd}$ isotopic composition and time-integrated low $\mathrm{Rb} / \mathrm{Sr}$ and high $\mathrm{Sm} / \mathrm{Nd}$ ratios.

The hypothesis involving closed-system fractionation from primary, mantle-derived magmas, however, remains to be tested. Were all rock types in the Guacimal Pluton a part of a single 'line of descent' from primary, mantle-derived magmas, one would expect to encounter large volumes of mafic cumulates and increasingly less abundant products of the magma differentiation. In reality, the distribution is close to bimodal, with the bulk of the intrusion being built by the felsic types. The mafic rocks are rather rare, forming only infrequent, small discrete bodies. Moreover, there is conspicuous discontinuity in the geochemical trends (e.g., the $\mathrm{SiO}_{2}-\mathrm{K}_{2} \mathrm{O}$ plot, Fig. 12f or the REE patterns, Fig. 13b). This reasoning is valid only for conventional models of crystal fractionation, whereby the individual crystals or their clusters separate from prevailing melt, though. Based on Bachmann and Bergantz (2004), Vogel et al. (2004, $2006,2007)$ proposed an alternative scenario for genesis of the silicic ignimbrites in Costa Rica. In their view, the parental silicic magmas represent limited amounts of fractionated liquid squeezed out from lower crustal crystal mush (containing 50-60\% of crystals according to Bachmann and Bergantz 2008), mainly amphibole and plagioclase, along with lesser amounts of pyroxene (Vogel et al. 2007).

In order to test the prospective role of fractional crystallization in genesis of the felsic suite, constrained leastsquares method (Albarède 1995) has been applied to the major-element analyses using an unpublished $\mathrm{R}$ language routine written for the GCDkit (Janoušek et al. 2006). The input data were the composition of the most primitive (parental) melt (the least siliceous sample Ju98), that of the presumed residual magma (the most $\mathrm{SiO}_{2}$-rich sample Ju346) and those of the likely crystallizing mineral phases. The model took into account $\mathrm{SiO}_{2}, \mathrm{Al}_{2} \mathrm{O}_{3}, \mathrm{FeOt}, \mathrm{MnO}$, $\mathrm{MgO}, \mathrm{CaO}, \mathrm{Na}_{2} \mathrm{O}$ and $\mathrm{K}_{2} \mathrm{O}$. The calculation suggests that the compositional spectrum of the felsic suite can be reproduced by limited fractionation $(\sim 15 \%)$ of $54.9 \% \mathrm{Pl}$, $22.4 \% \mathrm{Kfs}, 9.2 \% \mathrm{Hbl}, 8.1 \% \mathrm{Bt}$ and $5.4 \% \mathrm{Mgt}$ (Tab. 6). The fit is good, as indicated by the low value of the sum of squared residuals $\left(\mathrm{R}^{2}=0.23\right)$. Moreover, the calculated cumulate composition falls within the compositional range known from the mafic suite.

Tab 6 Least-squares modelling of fractional crystallization

\begin{tabular}{|c|c|c|c|c|c|c|c|c|c|c|}
\hline & $\begin{array}{c}\text { Parent } \\
\text { Ju98 }\end{array}$ & $\begin{array}{c}54.9 \% \\
\text { Pl }\end{array}$ & $\begin{array}{c}22.4 \% \\
\text { Kfs }\end{array}$ & $\begin{array}{c}9.2 \% \\
\mathrm{Hbl}\end{array}$ & $\begin{array}{c}8.1 \% \\
\mathrm{Bt}\end{array}$ & $\begin{array}{c}5.4 \% \\
\mathrm{Mgt}\end{array}$ & $\begin{array}{c}\text { Daughter } \\
\text { Ju346 }\end{array}$ & Calculated & Difference & Cumulate \\
\hline $\mathrm{SiO}_{2}$ & 68.83 & 60.46 & 63.42 & 41.12 & 38.25 & 0.01 & 71.55 & 71.41 & 0.14 & 54.30 \\
\hline $\mathrm{TiO}_{2}$ & 0.43 & 0.00 & 0.00 & 2.30 & 4.16 & 0.31 & 0.29 & 0.41 & -0.12 & 0.57 \\
\hline $\mathrm{Al}_{2} \mathrm{O}_{3}$ & 14.91 & 24.01 & 18.79 & 12.22 & 12.80 & 0.13 & 14.15 & 14.09 & 0.06 & 19.56 \\
\hline $\mathrm{FeOt}$ & 2.72 & 0.38 & 0.13 & 11.69 & 12.30 & 94.25 & 2.03 & 1.89 & 0.14 & 7.37 \\
\hline $\mathrm{MnO}$ & 0.11 & 0.00 & 0.00 & 0.18 & 0.12 & 0.11 & 0.10 & 0.12 & -0.02 & 0.03 \\
\hline $\mathrm{MgO}$ & 0.77 & 0.00 & 0.00 & 14.33 & 17.64 & 0.00 & 0.64 & 0.42 & 0.22 & 2.75 \\
\hline $\mathrm{CaO}$ & 2.44 & 5.98 & 0.09 & 11.55 & 0.00 & 0.04 & 2.21 & 2.10 & 0.11 & 4.37 \\
\hline $\mathrm{Na}_{2} \mathrm{O}$ & 3.56 & 8.12 & 1.98 & 2.51 & 0.51 & 0.02 & 3.55 & 3.27 & 0.28 & 5.17 \\
\hline $\mathrm{K}_{2} \mathrm{O}$ & 3.86 & 0.64 & 13.19 & 0.46 & 9.28 & 0.00 & 4.00 & 3.82 & 0.18 & 4.10 \\
\hline
\end{tabular}




\section{Conclusions}

The Guacimal Pluton forms an oval-shaped body $(\sim 15$ by 4-6 km), strongly elongated in the NW-SE direction. By its exposed surface of $60-70 \mathrm{~km}^{2}$ it represents the largest plutonic mass in the NW Costa Rica. The pluton intruded the Aguacate Group and is surrounded by a wide metasomatic aureole of calc-silicate rocks, derived from mafic volcanics. The pluton is formed by a felsic (granite-granodiorite) and a mafic suite (mainly quartz diorite to quartz monzodiorite/monzogabbro); the former strongly prevails.

The new LA ICP-MS zircon dating from granites yielded statistically identical $\mathrm{U}-\mathrm{Pb}$ ages of $6.3 \pm 0.5$ and $6.0 \pm 0.4 \mathrm{Ma}$. The late Miocene Guacimal granites thus belong to one of the youngest Neogene intrusions in Costa Rica, together with the Escazú Pluton, the youngest plutonic members of the Talamanca Igneous Suite and the Guacayán Intrusion.

Based on amphibole geobarometry, the emplacement depth of the Guacimal Pluton was approximately $3 \mathrm{~km}$. Such a shallow solidification level is also supported by the occurrence of micrographic structures and abundant miarolitic cavities. The near solidus crystallization temperatures of $c$. $760-800{ }^{\circ} \mathrm{C}$ were estimated by plagioclase-amphibole and zircon saturation thermometers. The presence of the assemblage quartz, magnetite, titanite, and $\mathrm{Mg}$-rich amphibole indicates a relatively high oxygen fugacity, 1.6-2.1 log units above the NNO buffer. During solidification, high $\mathrm{Al}$ and $\mathrm{F}$ contents in titanite and the presence of epidote and chlorite in miarolitic cavities document increasing activity of volatiles (fluorine and water).

The $\mathrm{Sr}-\mathrm{Nd}$ isotopic signatures of the Guacimal monzogranites and granodiorites are primitive and show only very limited variation, which precludes for opensystem processes such as magma mixing or assimilation of isotopically contrasting upper continental crust. The conventional extensive fractionation of depleted-mantle derived magmas is considered unlikely, as it would produce only relatively small volume of felsic magmas and large amounts of cumulates, for presence of which any evidence is lacking. Instead the $\mathrm{Sr}-\mathrm{Nd}$ isotopic data, together with the rest of the whole-rock geochemical signature, indicate either crystallization from a highly fractionated melt separated from a plagioclase-amphibole-dominated crystal mush in a putative deep crustal reservoir, or partial melting of older arc-related rocks (see the characteristic LILE/HFSE enrichments as well as the slight shift to more radiogenic ${ }^{87} \mathrm{Sr} /{ }^{86} \mathrm{Sr}$ ratios caused by slab-derived fluids). If true, the latter scenario would require a source with relatively unradiogenic $\mathrm{Sr}$, radiogenic $\mathrm{Nd}$, low time-integrated $\mathrm{Rb} / \mathrm{Sr}$ and comparably high $\mathrm{Sm} /$ $\mathrm{Nd}$ ratios and thus could have encompassed intermediate lavas or volcaniclastics or immature psammitic sedi- ments, such as graywackes rich in volcanogenic detritus. Limited variation observed in the felsic suite was most likely produced by low degrees $(\sim 15 \%)$ of closed-system fractional crystallization of an assemblage dominated by feldspars (c. $55 \%$ plagioclase, $23 \%$ K-feldspar, $9 \%$ amphibole, $8 \%$ biotite and $5 \%$ magnetite). At least some of the rocks of the volumetrically subordinate mafic suite may represent lithologies rich in the complementary cumulates.

Acknowledgements. This paper resulted from the International project No RP/6/2007 of Ministry of Environment of the Czech Republic, which was led by Petr Hradecký and Petr Kycl. The fieldwork was carried out by geologists of the Czech Geological Survey (CGS) in cooperation with the Department of Geology and Mines (DGM) of Ministry of Environment, Energy and Telecommunications of Costa Rica (MINAET) in 2006-2009. In the field works (sheet Juntas) participated also other colleagues from both Czech Republic and Costa Rica: Stanislav Čech, Barbora Dudík Schulmannová, Gino Gonzales, Radek Grygar, Petr Hrazdíra, Jana Karenová, Petr Lukeš, Enrique Quintanilla, Josef Ševčík, and Tomáš Vorel. The authors are also obliged to Radek Škoda, Masaryk University Brno, for obtaining electron microprobe analyses, František Laufek and Irena Haladová (CGS) for acquiring XRD data and František Veselovský (CGS) for separation of zircons for dating. The reviewers, Thomas Vogel and Lawford Anderson, as well as handling editor David Dolejš, provided helpful comments on the manuscript that improved its quality.

Electronic supplementary material. The GPS coordinates of the analysed samples, as well as selected mineral analyses of feldspars (Appendix 1), biotite and orthopyroxene (Appendix 2), magnetite (Appendix 3), ilmenite (Appendix 4), titanite (Appendix 5) and epidote-group minerals with prehnite (Appendix 6) are available online at the Journal web site (http://dx.doi.org/10.3190/jgeosci.087).

\section{References}

Abratis M (1998) Geochemical Variations in Magmatic Rocks from Southern Costa Rica as a Consequence of Cocos Ridge Subduction and Uplift of the Cordillera de Talamanca. Unpublished PhD. Thesis, Georg-AugustUniversität, Göttingen, pp 1-148

Albarède F (1995) Introduction to Geochemical Modeling. Cambridge University Press, Cambridge, pp 1-543

AlCORN SR (1981) Mineralogy, Petrology and Evolution of a Calc-Alkaline Igneous Sequence, Cerros de Tilarán, Puntarenas, Costa Rica. Unpublished MSci. Thesis, University of Georgia, Athens, pp 1-178 
Alvarado Ge, Kussmaul S, Chiesa S, Gillot P-Y, Appel H, Wörner G, Rundle C (1992) Resumen cronoestratigráfico de las rocas ígneas de Costa Rica basado en dataciónes radiométricas. J South Am Sci 6: 151-168

Alvarado GE, Denyer P, Sinton CW (1997) The 89 Ma Tortugal komatiitic suite, Costa Rica: implications for a common geological origin of the Caribbean and Eastern Pacific region from a mantle plume. Geology 25: 439-442

Amos BJ, Rogers PJ (1983) The geology and exploration geochemistry of the Cordillera Tilarán - Montes del Aguacate gold field, Costa Rica. British Geological Survey, Institute of Geological Sciences, Overseas Division, Open-File Report No 1983/3, pp 1-33

ANDERSON JL (1996) Status of thermobarometry in granitic batholiths. Trans Roy Soc Edinb, Earth Sci 87: 25-138

Anderson JL Smith DR (1995) The effects of temperature and $f_{02}$ on the Al-in-hornblende barometer. Amer Miner 80: 549-559

Appel H (1990) Geochemie und K-Ar Datierungen an Magmatiten in Costa Rica, Zentralamerika. Unpublished MSci. Thesis, University of Mainz, pp 1-149

Astorga A (1987) El Cretácico Superior y el Paleógeno de la vertiente pacifica de Nicaragua meridional y Costa Rica septentrional: origen, evoluticón y dinámica de las cuencas profundas relacionadas al margen convergente de Centroamérica. Unpublished MSci. Thesis, Univesidad de Costa Rica, San José, pp 1-115

Atherton M, Petford N (1993) Generation of sodium-rich magmas from newly underplated basaltic crust. Nature 362: $144-146$

Azambre B, Tournon J (1977) Les intrusions basiques alcalines du Río Reventazon (Costa Rica). C R Somm Soc Geol Fr 2: 104-107

Bachmann O, Bergantz G W (2004) On the origin of crystal-poor rhyolites: extracted from batholithic crystal mushes. J Petrol 45: 1565-1582

Bachmann O, Bergantz GW (2008) Rhyolites and their source mushes across tectonic settings. J Petrol 49: 2277-2285

Baumgartner PO, Denyer P (2006) Evidence for middle Cretaceous accretion at Santa Elena Peninsula (Santa Rosa Accretionary Complex), Costa Rica. Geol Acta 4: 179-191

Bellon H, Tournon J (1978) Contribution de la géochronometrie K-Ar a l'étude du magmatisme de Costa Rica, Amérique Central. Bull Soc Geol de France 20: 955-959

BergoeING JP (1982) Dataciones radiométricas de algunas muestras de Costa Rica. Instituto Geográfico Nacional Informe Semestral enero-diciembre 28: 71-86

Boynton WV (1984) Cosmochemistry of the rare earth elements: meteorite studies. In: HeNDERSON P (ed) Rare Earth Element Geochemistry. Elsevier, Amsterdam, pp 63-114
Carr MJ, Patino LC, Feigenson MD (2007) Petrology and geochemistry of lavas. In: Bundschuh J, Alvarado GE (eds) Central America: Geology, Resources and Hazards. Taylor \& Francis, London, pp 565-590

Chaves R, SÁenz R (1974) Geología de Cordillera de Tilarán (proyecto de Aguacate, $2^{\text {a }}$ Fase). Costa Rica, Dirección de Geología, Minas y Petróleo, Informes Técnicos y Notas Geológicas 12(53): 1-49

Cigolini C, Chaves R (1986) Geological, petrochemical and metallogenetic characteristics of the Costa Rican gold belt: contribution to new exploration. Geol Rundsch 75: 737-754

Corfu F, Hanchar JM, Hoskin PWO, Kinny P (2003) Atlas of zircon textures. In: HANCHAR JM, HoskIn PWO (eds) Zircon. Mineralogical Society of America and Geochemical Society Reviews in Mineralogy and Geochemistry 53: 469-503

Davidson J, Turner S, Handley H, Macpherson C, Dosseto A (2007) Amphibole "sponge" in arc crust? Geology 35: 787-790

De Boer JZ, Drummond M, Bordelon M, Defand M, BelLON H, Maury R (1995) Cenozoic magmatic phases of the C. R. island arc (Cordillera de Talamanca). In: Mann P (ed) Geologic and Tectonic Development of the Caribbean Plate Boundary in Southern Central America. Geological Society America Special Papers 295: 35-55

Debon F, Le Fort P (1983) A chemical-mineralogical classification of common plutonic rocks and associations. Trans Roy Soc Edinb, Earth Sci 73: 135-149

Debon F, Le Fort P (1988) A cationic classification of common plutonic rocks and their magmatic associations: principles, method, applications. Bull Minéral 111: 493-510

Dengo G (1962) Tectonic-igneous sequence in Costa Rica. In: Engel AEJ, James HJ, Leonard BF (eds) Petrologic Studies. A volume to honor A. F. Buddington. Geological Society of America, New York, pp 133-161

Denyer P, Alvarado GE (2007) Mapa Geológico de Costa Rica 2007. Libreria Francesa, San José

DenYer P, Arias O (1991) Estratigrafia de la región central de Costa Rica. Rev geol Amer Central 12: 1-59

Denyer P, Baumgartner PO, Gazel E (2006) Characterization and tectonic implications of Mesozoic-Cenozoic oceanic assemblages of Costa Rica and Western Panama. Geol Acta 4: 219-235

Donelly TW, Beets D, Carr MJ, Jackson T, Klaver G, Lewis J, Maury R, Schellkens H, Smith AL, Wadge G, Westercamp D (1990) History and tectonic setting of Caribbean magmatism. In: Dengo G, CASE J (eds) The Geology of North America, Volume $\mathrm{H}$ - The Caribbean Region. Geological Society of America, Boulder (CO), pp 339-374

Drummond MS, Bordelon M, De Boer J, Defant MJ, Bellon H, FeIgenson MD (1995) Igneous petrogenesis 
and tectonic settings of plutonic and volcanic rocks of Cordillera de Talamanca, Costa Rica-Panama, Central American Arc. Amer J Sci 295: 875-919

Dunstan LP, Gramlich JW, Barnes IL, Purdy WC (1980) The absolute abundance and the atomic weight of a reference sample of thallium. J Res Natl Bur Stand 85: 1-10

Feigenson MD, Carr MJ (1986) Positively correlated Nd and $\mathrm{Sr}$ isotope ratios of lavas from the Central American volcanic front. Geology 14: 79-92

Feigenson MD, Carr MJ, Maharaj SV, Juliano S, Bolge LL (2004) Lead isotope composition of central American volcanoes: influence of the Galapagos plume. Geochem Geophys Geosyst 5: DOI: 10.1029/2003GC000621

Foley SF, Venturelli G, Green DH, Toscani L (1987) Ultrapotassic rocks: characteristics, classification and constraints for petrogenetic models. Earth Sci Rev 24: $81-134$

Franz G, Spear FS (1984) Aluminous titanite (sphene) from the Eclogite Zone, south-central Tauern Window, Austria. Chem Geol 50: 33-46

Gans PP, MacMillan I, Alvarado Ge, Pérez W, Sigarán C (2002) Neogene evolution of the Costa Rican Arc. Geological Society of America Abstracts with Programs 34(6): 513

Gans PP, Alvarado Ge, Perez W, MacMillan I, Calvert A (2003) Neogene evolution of the Costa Rican Arc and development of the Cordillera Central. Geological Society of America Abstracts with Programs 35(4): 74

Gazel E (2003) Las series alcalinas del Plioceno de Costa Rica: distribución espacial y relación con una fuente mantélica tipo OIB. Rev geol Amer Central 29: 87-93

Gazel E, Carr M, Hoernle K, Feigenson MD, Szymanski D, HaufF F, BogaARd P (2009) Galapagos-OIB signature in southern Central America: mantle refertilization by arc-hot spot interaction. Geochem Geophys Geosyst 10: DOI: 10.1029/2008GC002246

Gillot P-Y, Chiesa S, Alvarado GE (1994) Chronostratigraphy of upper Miocene-Quaternary volcanism in northern Costa Rica. Rev geol Amer Central 17: 45-53

GRÄFE K (1998) Exhumation and thermal evolution of the Cordillera de Talamanca (Costa Rica): constraints from fission track analysis, ${ }^{40} \mathrm{Ar}-{ }^{39} \mathrm{Ar}$, and ${ }^{87} \mathrm{Rb}-{ }^{87} \mathrm{Sr}$ chronology. Tübinger Geowiss Arb A39: 1-113

Gromet LP, Silver LT (1983) Rare earth element distribution among minerals in a granodiorite and their petrogenetic implications. Geochim Cosmochim Acta 47: 925-939

Harpp KS, White WM (2001) Tracing a mantle plume: isotopic and trace element variations of Galápagos seamounts. Geochem Geophys Geosyst 2: DOI: 10.1029/2000GC000137

Harris N B W, Inger S (1992) Trace element modelling of pelite-derived granites. Contrib Mineral Petrol 110: $46-56$
Henningsen D (1966) Die pazifische Küstenkordillere (Cordillera Costeña) Costa Ricas und ihre Stellung innerhalb des südzentralamerikanischen Gebirges. Geotekt Forsch 23: 3-66

Hoernle K, Abt DL, Fischer KM, Nichols H, Hauff F, Abers G A, van den Bogaard P, Heydolph K, Alvarado G, Protti M, Strauch W (2008) Arc-parallel flow in the mantle wedge beneath Costa Rica and Nicaragua. Nature 451: 1094-1097

Holland TJB, Blundy JD (1994) Non-ideal interactions in calcic amphiboles and their bearing on amphiboleplagioclase thermometry. Contrib Mineral Petrol 116: 433-447

Horn I, Rudnick RL, McDonough WF (2000) Precise elemental and isotope ratio measurement by simultaneous solution nebulisation and laser ablation-ICP-MS: application to $\mathrm{U}-\mathrm{Pb}$ geochronology. Chem Geol 164: 281-301

Hoskin PWO, Kinny PD, Wyborn D, Chappell BW (2000) Identifying accessory mineral saturation during differentiation in granitoid magmas: an integral approach. J Petrol 41: 1365-1396

IrVINE TN, BARAGAR WRA (1971) A guide to the chemical classification of the common volcanic rocks. Can J Earth Sci 8: 523-548

Jackson Se, Pearson NJ, Griffin WL, Belousova EA (2004) The application of laser ablation-inductively coupled plasma-mass spectrometry to in situ U-Pb zircon geochronology. Chem Geol 211: 47-69

JaCoBsen SB, Wasserburg GJ (1980) Sm-Nd isotopic evolution of chondrites. Earth Planet Sci Lett 50: 139-155

JANOUŠEK V (2006) Saturnin, R language script for application of accessory-mineral saturation models in igneous geochemistry. Geol Carpath 57: 131-142

JANOUŠEK V, FARROW CM, ERBAN V (2006) Interpretation of whole-rock geochemical data in igneous geochemistry: introducing Geochemical Data Toolkit (GCDkit). J Petrol 47: 1255-1259

Janoušek V, Erban V, Holub FV, Magna T, Bellon H, MLČOCh B, Wiechert U, RAPPRICH V (2010) Geochemistry and genesis of behind-arc basaltic lavas from eastern Nicaragua. J Volcanol Geotherm Res 192: 232-256

Johannes W, Holtz F (1996) Petrogenesis and Experimental Petrology of Granitic Rocks. Springer, Berlin, pp 1-335

JUNG S, PFÄNDER JA (2007) Source composition and melting temperatures of orogenic granitoids: constraints from $\mathrm{CaO} / \mathrm{Na}_{2} \mathrm{O}, \mathrm{Al}_{2} \mathrm{O}_{3} / \mathrm{TiO}_{2}$ and accessory mineral saturation thermometry. Eur J Mineral 19: 859-870

Jung S, Masberg P, Mihm D, Hoernes S (2009) Partial melting of diverse crustal sources - constraints from $\mathrm{Sr}-\mathrm{Nd}-\mathrm{O}$ isotope compositions of quartz diorite-granodiorite-leucogranite associations (Kaoko Belt, Namibia). Lithos 111: 236-251 
Kessler SE, Sutter JF, Issogonis MJ, Jones LM, Walker RL (1977) Evolution of porphyry copper mineralization in Ocean Island Arc: Panama. Econ Geol 72: 1142-1153

KoŠLer J, Sylvester PJ (2003) Present trends and the future of zircon in geochronology: laser ablation ICPMS. In: Hanchar JM, Hoskin PWO (eds) Zircon. Mineralogical Society of America and Geochemical Society Reviews in Mineralogy and Geochemistry 53: 243-275

Košler J, Fonneland H, Sylvester PJ, Tubrett M, Pedersen $\mathrm{RB}$ (2002) U-Pb dating of detrital zircons for sediment provenance studies - a comparison of laser ablation ICPMS and SIMS techniques. Chem Geol 182: 605-618

KRETZ R (1983) Symbols for rock-forming minerals. Amer Miner 68: 277-279

Kussmaul S (1987) Petrología de las rocas intrusivas neogenas de Costa Rica. Rev geol Amer Central 7: 83-111

Kussmaul S (2006) Estratigrafía de las rocas ígneas In: Denyer P, Kussmaul S (eds) Geología de Costa Rica. Instituto Tecnológico de Costa Rica, San José, pp 63-86

Kussmaul S, Tournon J, Alvarado GE (1994) Evolution of the Neogene to Quaternary igneous rocks of Costa Rica. Profil 7: 97-123

KyCl P, ŽÁČEK V, Čech S, Grygar R, Hrazdíra P, Huapaya S, Karenová J, Kondrová L, Mendoza EQ, Metelka V, Mixa P, ŠEvčík J, Vorel T, Hradecká L, Rejchrt M, ŠvÁBENICKÁ L (2010) Estudio geológico, informe final (2006-2009): hojas 3246 II - Miramar, 3246 III Chapernal, 3246 IV - Juntas, Costa Rica. Unpublished manuscript, Czech Geological Survey, Prague and DGM, San José, pp 1-263

LAGunA MJ (1983) Hydrothermale Veänderung und Verwitterungseffekte in Vulkaniten der Aguacate Formacion (Miozän, Pliozän), Costa Rica, Zentralamerika. Zbl Geol Paläont 1: 223-233

LaGuna MJ (1984) Efectos de alteración hidrotermal y meteorización en volcanitas del Grupo Aguacate, Costa Rica. Rev geol Amer Central 1: 1-18

Leake BE, Wooley AR, Arps CES, Birch WD, Gilbert MC, Grice JD, Hawthorne FC, Kato A, Kisch HJ, KrivoviCheV VG, Linthout K, Laird J, Mandarino J, Maresch WV, Nickel EH, Rock NMS, Schumacher JC, Smith JC, Stephenson NCN, WhitTAKer EJW, Youzhi G (1997) Nomenclature of amphiboles: Report of the Subcommittee on Amphiboles of the International Mineralogical Association Commission on New Minerals and Mineral Names. Mineral Mag 61: 295-321

Liew TC, Hofmann AW (1988) Precambrian crustal components, plutonic associations, plate environment of the Hercynian Fold Belt of Central Europe: indications from a Nd and Sr isotopic study. Contrib Mineral Petrol 98: 129-138

Ludwig KR (1999) IsoplotEx v. 2.6. Berkeley Geochronological Center Special Publications 1a: 1-50

MacMillan I, Gans PB, Alvarado G (2004) Middle Miocene to present plate tectonic history of the southern
Central American Volcanic Arc. Tectonophysics 392: 325-348

MíkovÁ J, Denková P (2007) Modified chromatographic separation scheme for $\mathrm{Sr}$ and $\mathrm{Nd}$ isotope analysis in geological silicate samples. J Geosci 52: 221-226

Miller CF, McDowell SM, Mapes RW (2003) Hot and cold granites? Implications of zircon saturation temperatures and preservation of inheritance. Geology 31: 529-532

ONDRUŠ P, SKÁLA R (2004) ZDS-WX Search/Match. A computer program

OTTEN MT (1984) The origin of brown hornblende in the Artfjället gabbro and dolerites. Contrib Mineral Petrol 86: 189-199

PAtino LC (2007) Intrusive rocks. In: Bundschuh J, ALVARAdo GE (eds) Central America: Geology, Resources, Hazards, vol 1. Taylor and Francis, London, pp 549-564

Patiño Douce AE (1999) What do experiments tell us about relative contributions of crust and mantle to the origin of granitic magmas? In: CAstro A, Fernández C, VignerESSE JL (eds) Understanding Granites: Integrating New and Classical Techniques. Geological Society of London Special Publications 168: 55-75

Peccerillo A, Taylor SR (1976) Geochemistry of Eocene calc-alkaline volcanic rocks from the Kastamonu area, Northern Turkey. Contrib Mineral Petrol 58: 63-81

Pearce JA, Peate DW (1995) Tectonic implications of the composition of volcanic arc magmas. Ann Rev Earth Planet Sci 23: 251-285

Pin C, Zalduegui JFS (1997) Sequential separation of light rare-earth elements, thorium and uranium by miniaturized extraction chromatography: application to isotopic analyses of silicate rocks. Anal Chim Acta 339: 79-89

Pin C, Briot D, Bassin C, Poitrasson F (1994) Concomitant separation of strontium and samarium-neodymium for isotopic analysis in silicate samples, based on specific extraction chromatography. Anal Chim Acta 298: 209-217

Pouchou JL, Pichoir F (1985) 'PAP' $(\varphi-\rho-Z)$ correction procedure for improved quantitative microanalysis. In: Armstrong JT (ed) Microbeam Analysis. San Francisco Press, pp 104-106

RAPP RP, WATSON EB (1995) Dehydration melting of metabasalt at 8-32 kbar: implications for continental growth and crust-mantle recycling. J Petrol 36: 891-931

Ridolfi F, Renzulli A, Puerini M (2010) Stability and chemical equilibrium of amphibole in calc-alkaline magmas: an overview, new thermobarometric formulations and application to subduction-related volcanoes. Contrib Mineral Petrol 160: 45-66

Roberts MP, Clemens JD (1993) Origin of high-potassium, calc-alkaline, I-type granitoids. Geology 21: 825-828

Sadofsky S, Hoernle K, Duggen S, Hauff F, Werner R, GARBE-SCHÖNBERG D (2009) Geochemical variations in 
the Cocos Plate subducting beneath Central America: implications for the composition of arc volcanism and the extent of the Galápagos hotspot influence on the Cocos oceanic crust. Int J Earth Sci 98: 901-913

SAHAMA TG (1946) On the chemistry of the mineral titanite. C R Soc Geol Finlande 138: 88-122

Schulz K, Koeppen R, Ludington S, Kussmaul S, Gray K (1987) Volcanological framework for the gold deposits in the Cordillera de Tilarán and Montes del Aguacate, Costa Rica. In: Mineral Resource Assessment of the Republic of Costa Rica (USGS-DGMPUCR). USGS Miscellaneous Investigation Series Map 1-1865: 34-75

Sisson TW, Ratajeski K, Hankins WB, GlazNer AF (2005) Voluminous granitic magmas from common basaltic sources. Contrib Mineral Petrol 148: 635-661

Stacey JS, Kramers JD (1975) Approximation of terrestrial lead isotope evolution by a two-stage model. Earth Planet Sci Lett 26: 207-221

StRECKEISEN A (1974) Classification and nomenclature of plutonic rocks. Geol Rundsch 63: 773-786

Sun SS, McDonough WF (1989) Chemical and isotopic systematics of oceanic basalts: implications for mantle composition and processes. In: SAUNDERS AD, NORRY M (eds) Magmatism in Ocean Basins. Geological Society of London Special Publications 42: 313-345

SyLVESTER PJ (1998) Post-collisional strongly peraluminous granites. Lithos 45: 29-44

TATsumi Y, EgGins S (1995) Subduction Zone Magmatism. Frontiers in Earth Sciences, Blackwell, Cambridge, Mass., pp 1-211

Tiepolo M, Oberti R, Vannucci R (2002) Trace-element incorporation in titanite: constraints from experimentally determined solid/liquid partition coefficients. Chem Geol 191: 105-119

Tiepolo M, Oberti R, Zanetti A, Vannucci R, Foley S F (2007) Trace-element partitioning between amphibole and silicate melt. In: Hawthorne F C, Oberti R, Della Ventura G, Mottana A (eds) Amphiboles. Crystal chemistry, Occurrence and Health Issues. Mineralogical Society of America and Geochemical Society Reviews in Mineralogy and Geochemistry 67: pp 417-452

Tournon J (1984) Magmatismes du Mesozoique a l'actuel en Amerique Centrale: l'example de Costa Rica, des ophiolites aux andesites. Unpublished PhD. Thesis, Université Pierre et Marie Curie, France, pp 1-335

Ulloa A, Delgado C (2010) Características geoquímicas y mineralogía del flanco Pacífico central de la Cordillera de Talamanca: implicaciones para la evolución de una corteza continental. Unpublished Thesis, Universidad de Costa Rica, San José, pp 1-135

Villegas FA (1997) Geodinamica de la Cordillera de Tilarán, relacion entre la volcanologia y la tectonica.
Unpublished manuscript, Universidad de Costa Rica, San José, pp 1-147

Villegas FA (2004) La formación Alto Palomo: flujos pumíticos de la Cordillera Volcánica Central, Costa Rica. Rev geol Amer Central 30: 73-81

Vogel TA, Patino LC, Alvarado GE, Gans PB (2004) Silicic ignimbrites within the Costa Rican volcanic front: evidence for the formation of continental crust. Earth and Planetary Science Letters 226: 149-159

Vogel ta, Patino LC, Eaton JK, Valley JW, Rose Wi, Alvarado GE, Viray E L (2006) Origin of silicic magmas along the Central American volcanic front: genetic relationship to mafic melts. J Volcanol geotherm Res 156: $217-228$

Vogel TA, Patino LC, Alvarado Ge, Rose WI (2007) Petrogenesis of ignimbrites. In: BundSCHUH J, ALVARADO GE (eds) Central America: Geology, Resources, and Hazards. Taylor \& Francis, London, pp 591-618

Wasserburg GJ, Jacobsen SB, DePaolo DJ, McCulloch MT, Wen T (1981) Precise determination of Sm/Nd ratios, $\mathrm{Sm}$ and $\mathrm{Nd}$ isotopic abundances in standard solutions. Geochim Cosmochim Acta 45: 2311-2324

WATSON EB, HARRISON TM (1983) Zircon saturation revisited: temperature and composition effects in a variety of crustal magma types. Earth Planet Sci Lett 64: 295-304

Weyl R (1980) Geology of Central America. Gebrüder Bornträger, Berlin, pp 1-371

Wolf MB, Wyllie PJ (1994) Dehydratation-melting of amphibolite at $10 \mathrm{kbar}$ : the effects of temperature and time. Contrib Mineral Petrol 115: 369-383

WonEs DR (1989) Significance of the assemblage titanite + magnetite + quartz in granitic rocks. Amer Miner 74: 744-749

Žáček V, Kycl P, Huapaya S, Pécskay Z, Vorel T, Mixa P, Grygar R, Metelka V, Hradecký, P, Ševcí́ J (2008) Resultados preliminares del levantamiento geológico de la hoja Miramar, escala 1:50 000. Cooperación geológica Costa Rica-República Checa. Memoria: Programa y resúmenes, IX Congreso Geológico de América Central y VI Congreso geológico Nacional, 02-04 Julio, 2008, San José, Costa Rica, p 212

ŽÁČek V, Vorel T, Kycl P, Huapaya S (2010a) Mapa geológico 1:50 000, hoja 3246-II Miramar, República de Costa Rica. Czech Geological Survey, Prague, ISBN 978-80-7075-743-7

Žáček V, Čech S, Havlíček P, Vorel T, Dudík Schulmannová B, Kycl P, Huapaya S (2010b) Mapa geológico 1:50 000, hoja 3246-III Chapernal, República de Costa Rica. Czech Geological Survey, Prague, ISBN 978-807075-744-4

Žáčer V, Č́ech S, Dudík Schulmannová B, Vorel T, Kycl P, HuApaya S (2010c) Mapa geológico 1:50 000, hoja 3246-IV Juntas, República de Costa Rica. Czech Geological Survey, Prague, ISBN 978-80-7075-745-1 